University of Pennsylvania Carey Law School

Penn Law: Legal Scholarship Repository

Faculty Scholarship at Penn Law

1997

\title{
Liberalized Immigration as Free Trade: Economic Welfare and the Optimal Immigration policy
}

\author{
Howard F. Chang \\ University of Pennsylvania Carey Law School
}

Follow this and additional works at: https://scholarship.law.upenn.edu/faculty_scholarship

Part of the Business Law, Public Responsibility, and Ethics Commons, Commercial Law Commons, Constitutional Law Commons, Family, Life Course, and Society Commons, Immigration Law Commons, International and Comparative Labor Relations Commons, International Business Commons, International Economics Commons, International Trade Law Commons, Labor and Employment Law Commons, Labor Economics Commons, Law and Economics Commons, Law and Race Commons, Law and Society Commons, Race and Ethnicity Commons, Transnational Law Commons, and the Work, Economy and Organizations Commons

\section{Repository Citation}

Chang, Howard F., "Liberalized Immigration as Free Trade: Economic Welfare and the Optimal Immigration policy" (1997). Faculty Scholarship at Penn Law. 1403.

https://scholarship.law.upenn.edu/faculty_scholarship/1403

This Article is brought to you for free and open access by Penn Law: Legal Scholarship Repository. It has been accepted for inclusion in Faculty Scholarship at Penn Law by an authorized administrator of Penn Law: Legal Scholarship Repository. For more information, please contact PennlawIR@law.upenn.edu. 


\title{
LIBERALIZED IMMIGRATION AS FREE TRADE: ECONOMIC WELFARE AND THE OPTIMAL IMMIGRATION POLICY
}

\author{
HOWARD F. CHANG ${ }^{\dagger}$
}

INTRODUCTION

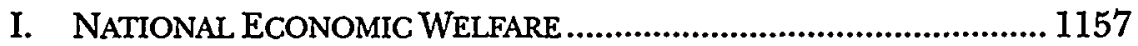

A. Effects of Immigration Through the Labor Market..................... 1158

B. External Effects of Immigration..............................................1163

C. The Optimal Tariff on Unskilled Immigrants............................. 1166

D. The Optimal Tariff on Skilled Immigrants................................ 1168

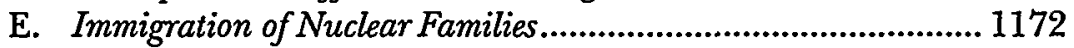

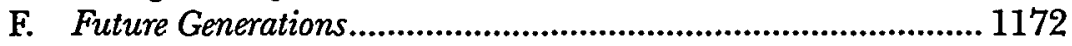

G. Avoiding External Costs ........................................................... 1176

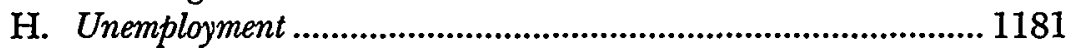

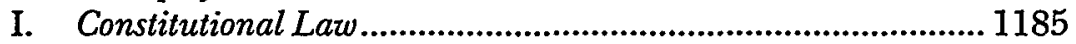

J. Citizenship, Guestworkers, and Illegal Immigration ................... 1190

K. Family-Based Immigration as a Negative Tariff ......................... 1198

L. Distributive Justice...................................................................... 1207

M. Preferences for the Ethnic Status Quo....................................... 1210

II. CONCERN FOR THE WELFARE OF IMMIGRANTS ............................ 1221

A. The Optimal Tariff.................................................................... 1222

B. The Optimal Quota..................................................................... 1225

† Associate Professor of Law, University of Southern California Law School; Visiting Associate Professor of Law, Georgetown University Law Center. A.B., 1982, J.D., 1987, Harvard University; M.P.A., 1985, Princeton University; Ph.D., 1992, Massachusetts Institute of Technology. I wish to thank Scott Altman, Lucian Bebchuck, Raj Bhala, Joseph Carens, Alan Deardorff, Mary Dudziak, Robert Ellickson, Thomas Griffith, Keith Hylton, Hiroshi Motomura, Kevin Johnson, Louis Kaplow, Gregory Keating, Michael Knoll, Martin Levine, Saul Levmore, Edward McCaffery, Gerald Neuman, Daniel Ortiz, Eric Posner, Peter Schuck, Warren Schwartz, Michael Shapiro, Steven Shavell, Hilary Sigman, Julian Simon, Larry Simon, David Slawson, Edwin Smith, Matthew Spitzer, Christopher Stone, Jeff Strnad, Eric Talley, Michael Trebilcock, Charles Weisselberg, and workshop participants at the University of Southern California Law School, the Georgetown University Law Center, the University of Pennsylvania Law School, and Harvard Law School for useful comments. I also gratefully acknowledge financial support from the James H. Zumberge Faculty Research and Innovation Fund at the University of Southern California and the John M. Olin Program in Law and Economics at the Georgetown University Law Center. 
C. The Optimal Allocation of Visas Subject to Quotas.................... 1228

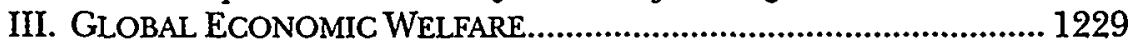

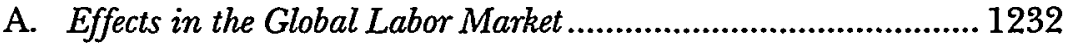

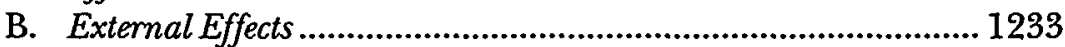

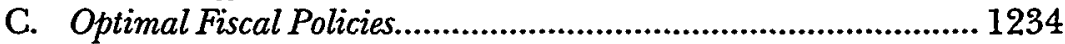

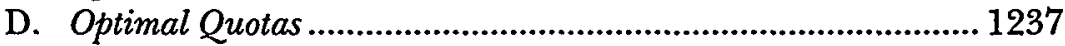

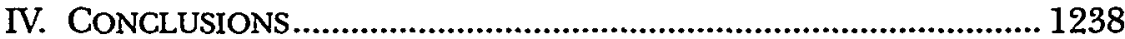

\section{INTRODUCTION}

Since multilateral trade negotiations produced the General Agreement on Tariffs and Trade ("GATT") ' in Geneva in 1947, the world has made dramatic progress toward free trade in goods. Several subsequent rounds of negotiations under GATT have steadily liberalized international trade, and numerous regional initiatives seek to deepen economic integration among countries prepared to go further. Standard economic theory prescribes free trade as the regime that maximizes global economic welfare. Economists also recommend trade liberalization as a policy that is likely to produce gains for each country.

The gains from trade will arise from the fact that different countries will produce various goods at different costs. When countries restrict trade, the price of a good will be low in countries that can produce the good at low cost, but its price will be high in countries that can produce the good only at higher cost. Liberalized trade allows both countries to gain. The high-price country can import the good at a price lower than the cost of producing the good at home; the lowprice country can export the good and receive a higher price than it would otherwise fetch.

Precisely the same theory applied to trade in goods also applies to trade in services. The Uruguay Round of trade negotiations recognized this fact in 1994, extending the international regulation of trade to service markets through the General Agreement on Trade in Services ("GATS"). ${ }^{2}$ Free trade in all services, including labor serv-

${ }^{1}$ General Agreement on Tariffs and Trade, Oct. 30, 1947, 61 Stat. pt. 5, 55 U.N.T.S. 187 [hereinafter GATT].

${ }^{2}$ General Agreement on Trade in Services, Apr. 15, 1994, 33 I.L.M. 1167 [hereinafter GATS]. For a summary of the GATS, see MiCHAEL J. TREBILCOCK \& ROBERT HOWSE, THE REgULATION OF INTERNATIONAL TRADE 225-36 (1995), Bernard Hoekman, The General Agreement on Trade in Services, in JOHN H. JACKSON ET AL., LEGAL PROBLEMS OF INTERNATIONAL ECONOMIC RELATIONS: CASES, MATERIALS AND TEXT 921 
ices, would imply free movement of people across borders. To provide many services, workers must cross borders to where the work must be performed, either on a temporary basis or to accept permanent employment. ${ }^{3}$ Thus, the free movement of workers across borders promotes economic welfare by promoting free trade in the labor market. ${ }^{4}$ The European Union recognizes the importance of free mobility of labor as an element of a comprehensive free trade regime, enshrining this freedom in its constitution as one of the "four freedoms" that are the basic pillars of the European common market, "an area without internal frontiers in which the free movement of goods, persons, services and capital is ensured." This "freedom of movement for workers" in turn entails "the abolition of any discrimination based on nationality between workers... with respect to employment."

Immigration barriers interfere with the free flow of labor internationally and thereby cause wage rates for the same class of labor to diverge widely among different countries. For any given class of labor, residents of high-wage countries could gain by employing more immigrant labor, and residents of low-wage countries could gain by selling more of their labor to employers in high-wage countries. Given

(3d ed. 1995), or Pierre Sauve, Assessing the General Agreement on Trade in Services-HalfFull or Half-Emply?, J. WORLD TRADE, Aug. 1995, at 125.

${ }^{9}$ Conversely, to consume services provided only in other countries, such as sightseeing for tourists or education for students, the consumer must travel abroad.

1 See Kevin R. Johnson, Free Trade and Closed Borders: NAFTA and Mexican Immigration to the United States, 27 U.C. DAVIS L. REV. 937, 964 (1994) ("True believers in the free market presumably would prefer the free flow of both labor and trade."). The Reagan administration's Council of Economic Advisors recognized the importance of the free flow of labor, noting: "Like international trade in goods ... international migration connects domestic and international markets. The free flow of resources in response to market signals promotes efficiency and produces economic gains for both producers and consumers. The migration of labor, both domestically and internationally, represents such a flow of productive resources." ECONOMIC REPORT OF THE PRESIDENT 213 (1986).

${ }^{5}$ TREATY ESTABLISHING THE EUROPEAN ECONOMIC COMMUNITY, Mar. 25, 1957, 298 U.N.T.S. 11 [hereinafter EEC TREATY] art. 8A (as amended 1987), art. 7A (as amended 1992); see Klaus F. Zimmermann, Tackling the European Migration Problem, J. ECON. PERSP., Spring 1995, at 45, 58 (1995) ("This implies the abolition of any restrictions on internal labor mobility, including internal border controls."). "By drafting the treaty this way, its authors-in common with many scholars-assumed a link between 'free trade' and the relatively free movement of labor." John A. Scanlan, A View from the United States-Social, Economic, and Legal Change, the Persistence of the State, and Immigration Policy in the Coming Century, 2 IND. J. Global LEGAL STUD. 79, 126 (1994) ("A bigger Europe without tariffs and fewer barriers to the movement of goods, capital, and people, it was argued, would be able to create bigger and more efficient firms, produce and sell goods more cheaply, and be in a much better position to compete in the world marketplace.").

${ }^{\circ}$ EEC TREATY art. 48(2). 
the large international differences in wages, it should be apparent that the potential gains from international trade in labor (and the costs we bear as a result of immigration barriers) are large.

Indeed, studies suggest that the gains to the world economy from removing immigration barriers could well be enormous and greatly exceed the gains from removing trade barriers. For example, Bob Hamilton and John Whalley provide estimates that suggest that the gains from free migration of labor would more than double worldwide real income, indicating that immigration controls "are one of the (and perhaps the) most important policy issues facing the global economy." Even their most conservative estimate suggests that the gains would be a significant fraction (over thirteen percent) of worldwide real income.' Furthermore, their analysis indicates that the free migration of labor would also greatly improve the global distribution of income by raising real wages dramatically for the world's poorest workers. $^{10}$

Recognizing the importance of immigration barriers as costly trade barriers, developing countries, especially India, have pressed for liberalized movement of labor as part of the liberalization of world trade in services. India, with the support of the Philippines, Egypt, Brazil, and Pakistan, has threatened to block progress on the liberali-

7 To some extent, international trade in goods can substitute for the free mobility of factors of production (including labor). International trade enables consumers in some countries to take advantage of the lower cost of labor in other countries by importing labor-intensive products. International trade will be a complete substitute for the free mobility of factors only if it causes "factor price equalization," which would equalize the cost of labor worldwide. Factor price equalization is possible in theory, but only under conditions that do not obtain in the real world. See, e.g., PAUL $\mathrm{R}$. KRUGMAN \& MAURICE OBSTFELD, INTERNATIONAL ECONOMICS: THEORY AND POLICY 79-81 (2d ed. 1991) (describing factor price equalization). For example, "factor prices need not be equalized between countries with radically different ratios of capital to labor or of skilled to unskilled labor." Id. at 76. Factor price equalization also requires that the price of all goods be equalized through international trade. The presence of natural barriers to trade (such as transportation costs) imply that many goods and services are not traded internationally. See Alan O. Sykes, The Welfare Economics of Immigration Law, in JUSTICE IN IMMIGRATION 158, 163 (Warren F. Schwartz ed., 1995) ("[D]ifferences across countries in factor returns can be attributed to differences in technology, to governmental barriers to trade, to transport costs and [to] the related fact that some goods and services are not 'tradeable' (certain perishables, haircuts) ....").

${ }^{8}$ Bob Hamilton \& John Whalley, Efficiency and Distributional Implications of Global Restrictions on Labour Mobility, 14 J. DEV. ECON. 61, 70 (1984).

${ }^{9}$ See id. at 71-72.

${ }^{10}$ See id. at 73-74; see also Scanlan, supra note 5, at 140 (noting that "eliminating borders" for "those seeking work" would "increase production, create wealth, and help reduce poverty"). 
zation of trade in financial services in the absence of progress on the "movement of natural persons," which is the subject of a parallel set of negotiations in the World Trade Organization ("WTO")." In spite of the large efficiency gains that liberalized immigration policies would produce, however, the authors of the GATS were careful to avoid imposing any obligations with respect to immigration policies. ${ }^{12}$ Similarly, in negotiating the North American Free Trade Agreement ("NAFTA"), ${ }^{18}$ the United States refused to discuss the liberalization of labor movement as an element of free trade. ${ }^{14}$

Indeed, in 1995 the U.S. Commission on Immigration Reform, headed by Barbara Jordan, urged Congress to move radically in the opposite direction, toward more restrictive immigration laws. ${ }^{15}$ The Jordan Commission recommended sweeping changes in longstanding U.S. immigration laws, including a reduction in the overall level of legal immigration into the United States by one-third. ${ }^{16}$ The proposed changes included permanent cuts in both employment-based and family-based immigration. ${ }^{17}$ These proposals would entail the most restrictive changes in U.S. immigration law since immigration

"See India Warns of Financial Services Link to Free Flow of Labor in Negotiations, 12 Int'l Trade Rep. 649 (BNA) (Apr. 12, 1995); Financial Services Committee Approves Accord Without U.S., 12 Int'l Trade Rep. (BNA) 1311, 1311 (Aug. 2, 1995).

${ }_{12}$ See GATS, supra note 2, Annex on Movement of Natural Persons Supplying Services Under the Agreement, para. 2, 33 I.L.M. 1187, 1187 [hereinafter GATS Annex] ("The Agreement shall not apply to measures affecting natural persons seeking access to the employment market of a Member, nor shall it apply to measures regarding citizenship, residence or employment on a permanent basis.").

is North American Free Trade Agreement, Dec. 17, 1992, 32 I.L.M. 289, 605.

${ }^{14}$ See Johnson, supra note 4, at 940 ("[T] he United States excluded the subject of labor migration from the bargaining table."); Scanlan, supra note 5, at 137-38 (noting "[ $t]$ he refusal of the United States to even consider bringing free labor migration under the NAFTA umbrella"); $i d$. at 86 ("NAFTA's drafters consciously chose to avoid creating an integrated continental labor market."). This position failed to acknowledge the "inconsistency between free trade and closed borders." Johnson, supra note 4, at 956.

is See U.S. COMM'N ON IMMIGRATION REFORM, LEGAL IMMIGRATION: SETIING PRIORITIES (1995) [hereinafter JORDAN COMM'N]. 'Despite all the 'globalism' talk about breaking down walls and collapsing boundaries, immigration talk is increasingly restrictionist." Kitty Calavita, U.S. Immigration Policy: Contradictions and Projections for the Future, 2 IND. J. GLOBAL LEGAL STUD. 143, 149-50 (1994).

${ }^{16}$ See JORDAN COMM'N, supra note 15, at xii; Robert Pear, Change of Policy on U.S. Immigrants Is Urged by Panel N.Y. TIMES, June 5, 1995, at A1.

${ }^{17}$ The Jordan Commission proposed permanent reductions in the numerical limits for employment-based admissions (from 140,000 to 100,000 per year) and for family-based admissions (from 480,000 to 400,000 per year). See JORDAN COMM'N, supra note 15 , at xii. The Commission also proposed the complete elimination of all familybased immigration categories other than nuclear family admissions. See id. at xviii. 
quotas were first introduced in $1921 .^{18}$ President Clinton immediately endorsed these proposals. ${ }^{19}$ Senator Alan Simpson and Representative Lamar Smith, both Republicans, soon introduced bills to implement the Jordan Commission's recommendations. ${ }^{20}$ With public opinion polls indicating that most voters believe that current immigration levels are excessive, ${ }^{21}$ many observers predicted that these bills would pass with bipartisan support. These radical cuts in legal immigration proved controversial, however, and after heated debate, both the House of Representatives and the Senate ultimately voted to exclude these cuts from their immigration reform bills. ${ }^{22}$ Observers expect restrictionists to revive these proposals in the near future. ${ }^{23}$ Yet, as Commissioner Warren Leiden observed in his statement dissenting from the Jordan Commission's proposal to reduce legal immigration, the Commission "can provide no convincing argument for this drastic reduction" because "there is no objective basis for a drastic reduction. ${ }^{24}$

${ }^{18}$ Immigration quotas are a relatively recent innovation: the United States did not introduce quantitative restrictions on immigration until 1921. See Act of May 19, 1921, ch. $8, \S 2$ (a), 42 Stat. 5,5 (temporary legislation superseded by permanent legislation in 1924). Thus, for most of our history, the United States admitted immigrants without numerical limits. As Kitty Calavita observes, "the irony is that in this period of globalization marked by its free movement of capital and goods, the movement of labor is subject to greater restrictions than at the dawn of the Industrial Revolution." Calavita, supra note 15, at 152.

${ }^{10}$ See Robert Pear, Clinton Embraces a Proposal to Cut Immigration by a Third, N.Y. TIMES, June 8,1995 , at B10. As a presidential candidate, Senator Bob Dole appeared to take a more moderate stand, endorsing "a modest, temporary reduction" in legal immigration. Presidential Candidates Hold Range of Views on Immigration, 73 INTERPRETER RELEASES 263, 263 (1996).

${ }^{20}$ See S. 1394, 104th Cong. (1995) (the Simpson bill); H.R. 2202, 104th Cong. (1995) (the Smith bill).

${ }^{21}$ See, e.g., Bruce W. Nelan, Not Quite So Welcome Anymore, Time, Special Issue, Fall 1993, at 10,11 (reporting that a Time poll found that $60 \%$ of those surveyed favored "changes in federal law to reduce the number of immigrants who enter the U.S. legally"); Rich Thomas, The Economic Cost of Immigration, NEWSWEEK, Aug. 9, 1993, at 18, 19 (reporting that a Newsweek poll found that $60 \%$ of those surveyed thought that immigration was "a bad thing for this country today").

${ }^{22}$ See House Approves Immigration Bill After Removing Legal Immigration Restrictions, 73 INTERPRETER RELEASES 349 (1996); Senate Approves Omnibus Immigration Bill After Removing Exclusion Provisions, 73 INTERPRETER RELEASES 601 (1996).

${ }^{23}$ See William Branigin, Immigration Issues Await New Congress: Surging Legal Influx Will Be Among Topics of Renewed Debate, WASH. POST, Nov. 18, 1996, at Al.

${ }^{24}$ JORDAN COMM'N, supra note 15 , at 229 . Leiden explains:

Virtually all the research and analysis received by the Commission indicated that [current] levels of legal immigration continue to provide a net positive benefit to America in a multitude of ways. Whatever interest is examined- 
In fact, as this Article will show, the application of trade principles to immigration law suggests instead that specific liberalizing reforms, which are likely to increase levels of employment-based and familybased immigration by eliminating certain immigration barriers, would raise national economic welfare as well as global economic welfare. In particular, this Article will begin with a focus on immigration for the purpose of employment, although the analysis will have implications for immigration in general. Employment-based immigration is largely justified on economic grounds, unlike refugee or familybased immigration, which raise other issues such as humanitarian considerations. I will turn to these other categories of immigration, however, as they become relevant to the analysis. I will use the term "immigration" in a broad sense, including not only the admission of aliens for permanent residence (on "immigrant" visas) but also the admission of guestworkers on a more temporary basis (on what are called "nonimmigrant" visas in the United States). ${ }^{25}$ Thus, I will focus on the issue of admission to the labor market of the host country, which does not necessarily imply access to citizenship in the host country. Given the importance of economic concerns in the public debate over immigration policy, I will focus on the implications of immigration for economic welfare, but I will also touch upon some noneconomic concerns as they relate to the economic analysis. ${ }^{26} \mathrm{Al}$ though my economic analysis applies to any country of immigration, my focus will be on the United States, and I will derive policy implications for the United States in particular.

Before reaching any conclusions regarding the optimal level of immigration, one must specify the criterion by which one will evalu-

economic, social, political, scientific, or cultural-the current levels of legal

immigration are found to benefit each of these aspects of American life.

Id. at 228; see MICHAEL FIX \& JEFFREY S. PASSEL, IMMIGRATION AND IMMIGRANTS: SETTING THE RECORD STRAIGHT 69 (1994) ("[T] he economic effects of immigration are largely positive.").

${ }^{25}$ U.S. law creates numerous categories of "nonimmigrant" aliens admitted to the United States on a temporary basis. 8 U.S.C. $\$ 1101$ (a)(15) (1994). These categories include not only students, see id. $\S 1101(\mathrm{a})(15)(\mathrm{F})$, and temporary visitors for business or pleasure, see id. $\S 1101(\mathrm{a})(15)(\mathrm{B})$, for example, but also temporary workers, see id. $\S 1101(\mathrm{a})(15)(\mathrm{H})$.

${ }^{26}$ For essays discussing the broader philosophical and moral issues raised by immigration barriers, see FREE MOVEMENT: ETHICAL ISSUES IN THE TRANSNATIONAL MIGRATION OF PEOPLE AND OF MONEY (Brian Barry \& Robert E. Goodin eds., 1992); JUSTICE IN IMMIGRATION, supra note 7; OPEN BORDERS? CLOSED SOCIETIES? THE ETHICAL AND POLmCAL IssuEs (Mark Gibney ed., 1988); and Joseph H. Carens, Aliens and Citizens: The Case for Open Borders, 49 REv. POL. 251 (1987). 
ate the effects of immigration. To shed light on our immigration laws, I will explore what policies would be optimal from the perspective of economic welfare. In evaluating the effects of immigration policies upon economic welfare, however, we must first address the question of whose welfare we are considering. Should we seek to maximize the welfare of natives alone, or does the welfare of immigrants count as well? Should we seek to maximize national economic welfare or global economic welfare? Once we decide whose welfare counts, we must also address whether our objective is merely to maximize their wealth (that is, to pursue economic efficiency with respect to their welfare) or whether our objectives also include an equitable distribution of wealth among them. If our objectives include distributive concerns, then our measure of social welfare must specify how much weight to give these concerns. We might adopt a utilitarian measure of social welfare, which would imply one criterion that would aggregate these objectives, or we might choose to maximize a more egalitarian measure of social welfare. Thus, the optimal immigration policy will depend upon what measure of social welfare we choose to maximize.

I will not set forth a full philosophical defense of any particular measure of social welfare. Instead, my strategy will be to explore the policy implications of several different measures of social welfare. I assume each measure in turn, for the sake of argument, and as a theoretical exercise, I will derive the optimal policy given that welfare objective. I conclude that under any reasonable measure of social welfare, optimal policies would probably entail higher levels of employment-based and family-based immigration than we currently allow into the United States. In particular, although the economic welfare of natives and distributive justice among natives are often advanced as reasons to reduce immigration, I will demonstrate that neither objective provides a sound justification for more restrictive laws regarding employment-based and family-based immigration.

In Part I, strictly as a thought experiment, I examine what policies the United States would pursue if its goal were simply to maximize the economic welfare of U.S. natives. I begin the analysis with an examination of immigration policies that efficiently promote the welfare of natives, setting aside questions of distribution. Standard trade theory prescribes free trade for any country that is too small to have any market power. If a country decides to protect an industry in spite of this prescription, then tariffs will do less harm to national economic welfare than import quotas. If the country is large enough to 
have some market power, then it can improve its own welfare by levying an appropriate tariff. I apply these lessons to trade in labor services and conclude that the United States should eliminate quantitative restrictions on employment-based immigration. Trade principles also suggest that the United States should eliminate its "labor certification" requirements for immigration visas. Optimal immigration policy would instead take the form of a "tariff," that is, a tax imposed on immigrants. This tariff could take the form of an income tax that discriminates between natives and immigrants.

Although some economists have previously suggested a tax on foreign workers, ${ }^{27}$ my analysis builds on that suggestion by exploring the features of the optimal immigration tariff in detail. This comprehensive analysis goes beyond the prior "optimal tariff" literature by taking account of both "market power" considerations and external effects from immigration through the public sector, such as congestion costs and effects on the public treasury, and by incorporating lessons drawn from the theory of externalities and "optimal tax" theory. Based on these considerations, I find that the optimal tariff is positive for immigrants with low income but is likely to be negative for immigrants with sufficiently high income. These results suggest that skilled immigration should be permitted (indeed encouraged) without quantitative or other protectionist restrictions and that unskilled immigration should be permitted without quantitative restrictions but subject to less generous fiscal policies than those applied to natives.

My analysis of the optimal tariff also adds to the prior literature by taking account of family-based immigration and exploring the extent to which current U.S. laws implement the optimal immigration tariff. In Part I.G, I address restrictions on the access of aliens to public entitlement programs, including sweeping new restrictions enacted by Congress in 1996, and characterize these restrictions as a positive tariff on low-income immigrants. In Part I.I, I briefly discuss the degree to which the U.S. Constitution constrains the power of Congress to impose a tariff on aliens, and I conclude that constitutional doctrine as it currently stands does not appear to bar such policies. In Part I.K, I address family-based immigration and characterize the ability to

${ }^{27}$ See, e.g., Jagdish N. Bhagwati \& T.N. Srinivasan, On the Choice Between Capital and Labour Mobility, 14 J. INT'L ECON. 209, 218-19 (1983); Barry R. Chiswick, The Impact of Immigration on the Level and Distribution of Economic Well-Being, in THE GATEWAY: U.S. IMMIGRATION ISSUES AND POLICIES 289, 308-10 (Barry R. Chiswick ed., 1982); Melvyn B. Krauss \& William J. Baumol, Guest Workers and Income-Transfer Programs Financed by Host Governments, 32 KYKLOS 36, 44 (1979); Sykes, supra note 7, at 180-82. 
sponsor relatives for immigration as a negative tariff that the United States reserves for relatively high-income immigrants, especially following new restrictions on sponsorship enacted by Congress in 1996.

In Part I.L, I introduce distributive justice among natives as an objective. Concern for the distribution of income among natives, however, does not imply that more restrictive immigration laws are in order. Instead, the appropriate response to distributive concerns is redistribution through progressive reforms of tax and transfer policies, not immigration restrictions. Combined with appropriate fiscal policies, liberalized immigration can make each class of natives better off.

In Part I.M, I address the question of whether preferences for the ethnic status quo should enter our analysis as a consideration. I argue that although one might in theory include the satisfaction of these preferences as an element of economic welfare, moral principles militate in favor of excluding these preferences from consideration as a matter of public policy. I survey some of the ethical problems raised by giving weight to such preferences given that these types of preferences would also support racial segregation and discrimination in the domestic context.

In the remainder of the paper, I relax the assumption of a purely nativist measure of social welfare. ${ }^{28}$ This extension of the analysis contributes to the existing literature by revealing how the optimal immigration policy varies with our welfare objectives. In Part II, I consider what policies the United States would pursue if it gave some weight to the welfare of immigrants. I consider not only the pursuit of economic efficiency in this context, but also issues of distributive justice. Once we give sufficient weight to the welfare of immigrants, the optimal immigration policy would feature more generous fiscal policies for poor immigrants than those that maximize the economic welfare of natives alone and would probably feature much more liberal levels of immigration than our current laws permit.

In Part III, I explore what policies would maximize global welfare. I consider not only global economic efficiency, but also global dis-

${ }^{28}$ I use the term "nativist" to refer to "the practice or policy of favoring native-born citizens as against immigrants." WEBSTER'S NEW WORLD DICTIONARY OF THE AMERICAN LANGUAGE 947 (David B. Guralnik ed., 2d college ed. 1976). Commentators often use "nativism" in a narrower sense to refer to a particular species of xenophobia in U.S. history. See, e.g., JOHN HIGHAM, STRANGERS IN THE LAND: PATIERNS OF AMERICAN NATIVISM 1860-1925, at 4 (2d ed. 1963) (defining "nativism" as "intense opposition to an internal minority on the ground of its foreign (i.e., 'un-American') connections"). 
tributive justice. These objectives imply immigration levels far higher than our laws currently permit. In Part IV, I explore the normative implications of my economic analysis and formulate proposals for liberalizing U.S. immigration laws in light of some of the political obstacles to such reforms.

\section{NATIONAL ECONOMIC WELFARE}

I begin my analysis with an examination of the pursuit of national economic welfare through immigration policy, not because I believe that immigration policy should be guided solely by considerations of economic self-interest, but because such concerns have played a dominant role in the public debate over immigration policy. ${ }^{29} \mathrm{Na}-$ tional governments, including the U.S. government, will probably continue to deem the promotion of the interests of natives as the paramount objective of immigration policies. ${ }^{30}$ I define national economic welfare narrowly, in terms of the economic welfare of natives (those born in the country of immigration). I adopt this strictly nativist measure of social welfare not because it is morally defensible, but because this nativist welfare objective is commonly thought to provide a strong case in favor of restrictive immigration laws. ${ }^{31}$

My economic analysis reveals, however, that even from this narrow perspective, which "stacks the deck" against the immigrant, optimal

${ }^{2}$ See, e.g., S. REP. NO. 98-62, at 3-4 (1983) ("[T]he paramount obligation of any nation's government, indeed the very reason for its existence and the justification for its power, is to promote the national interest-the long-term welfare of the majority of its citizens and their descendants."); JORDAN COMM'N, supra note 15, at 1-3 (introducing its report to Congress with a discussion of benefits, costs, and "the national interest"); VERNON M. BRIGGS, JR., MASS IMMIGRATION AND THE NATIONAL. INTEREST (1992).

so See Scanlan, supra note 5, at 79-83 (predicting that nations will continue to pursue self-interested immigration policies); see also id. at 107 ("[N]o State can afford to pursue a policy that does not promise clear benefits to enough of its constituents, if not immediately, then in the near future.").

31 One could define the national interest more broadly, to include the welfare of immigrants or other moral considerations. See John A. Scanlan \& O.T. Kent, The Force of Moral Arguments for a Just Immigration Policy in a Hobbesian Universe: The Contemporary American Example, in OPEN BORDERS? CLOSED SOCIETIES? THE ETHICAL AND POLITICAL ISSUES, supra note 26, at 61,78 ("[T] hose who invoke the national interest to justify restrictive immigration policies often ignore moral values that must be counted among the various kinds of interests that U.S. citizens hold."); HENRY SHUE, BASIC RIGHTS: SUBSISTENCE, AFFLUENCE, AND U.S. FOREIGN POLICY 141 (1980) (suggesting that even if "national leaders are to be expected ... to be advocates for the national interest," it remains "entirely possible that ... the people served by a particular national government would... themselves have transnational duties and that these citizens would ask their government to act in their behalf to coordinate the performance of the citizens' duties"). 
policies would probably allow higher levels of employment-based and family-based immigration than current U.S. immigration laws permit. Even if we give zero weight to the welfare of aliens in our measure of social welfare, the optimal immigration policy would be more liberal than our current laws in most important respects. First, I will consider the effects of immigration upon participants in labor markets, setting aside economic effects that operate outside the market. Second, I will extend the analysis to include the effects of immigration through the public sector.

\section{A. Effects of Immigration Through the Labor Market}

For a country with no market power in international markets, such that it cannot affect world prices, standard trade theory prescribes free trade to maximize national economic welfare. ${ }^{32}$ Import quotas or tariffs restrict trade and thereby sacrifice gains from trade. ${ }^{33}$ Protectionism imposes costs by driving up the price paid by domestic consumers for the goods in question. As a result, consumption falls (the "consumption effect"), leading to deadweight loss insofar as consumers forego consumption even if the value they would derive from it exceeds the amount paid to foreigners for the imported good. Domestic production also rises (the "production effect"), leading to deadweight loss insofar as productive resources are drawn from alternative uses more valuable than the amount paid to foreigners for the imported good. Domestic producers may gain from higher prices for their goods, but this gain comes only at the expense of consumers. Indeed, because protectionism causes distortions in domestic production and consumption, consumers lose more than domestic producers gain. The national economy as a whole suffers a net loss as a result of protectionism.

The same theory indicates that free immigration would maximize the gains from trade in the labor market for a country with no market power in foreign labor markets. Immigration restrictions impose costs by driving up the cost of labor, which in turn drives up the cost of goods and services to consumers. Native workers may gain from higher wages, but this gain comes only at the expense of employers in the host country and ultimately consumers. The increase in wages for domestic labor is a pure transfer from owners of other factors of pro-

32 See, e.g., KRUGMAN \& OBSTFELD, supra note 7, at 213-14.

${ }^{33}$ See, e.g., PETER B. KENEN, THE INTERNATIONAL ECONOMY 22-23, 188-89 (3d ed. 1994). 
duction (for example, capital) in the host country and from consumers. ${ }^{34}$ Immigration restrictions not only redistribute wealth among natives but also destroy wealth by causing economic distortions. Restrictions prevent employers from hiring foreign workers even if the value that they would produce exceeds the wage that would be paid to the worker: Immigration restrictions entail a sacrifice of this "immigration surplus," ${ }^{35}$ which is analogous to the harmful consumption effect from protectionism in a goods market. Domestic workers are drawn from alternative activities that would be more valuable than the wage that would be paid to foreign workers. This misallocation of labor is analogous to the harmful production effect from protectionism in a goods market. Thus, the U.S. private sector would benefit from the elimination of all restrictions on the immigration of labor, including unskilled workers as well as skilled workers. ${ }^{36}$

${ }^{34}$ To the extent that firms pass on their higher labor costs to consumers, the consumer bears the cost of immigration restrictions. Given the international mobility of capital, the return to capital would be constant in the long run for a country with no market power in the world capital market. Thus, in the long run, consumers and owners of immobile factors of production (for example, land) bear the full cost of immigration restrictions.

In theory, the costs of immigration restrictions may fall in part on foreign owners of capital invested in the host country. If so, then some of the benefits of liberalized immigration would go to these foreigners. See Sykes, supra note 7, at 167-68. Whereas foreign owners of capital would gain only in the short run, foreigners who own land in the host country would gain even in the long run. To ensure that natives capture these benefits, whether to capital in the short run or to land in the long run, the host country could impose a tax on the relevant assets and redistribute the revenue to natives. See infra Part I.L (suggesting tax and transfer policies to redistribute the benefits of liberalized immigration).

${ }^{35}$ George J. Borjas, The Economic Benefits from Immigration, J. ECON. PERSP., Spring 1995 , at 3,5 .

${ }^{56}$ George Borjas has claimed that current immigration into the United States is less skilled than it was in the past. See GEORGE J. BORJAS, FRIENDS OR STRANGERS: THE IMPACT OF IMMIGRANTS ON THE U.S. ECONOMY 133 (1990) [hereinafter BORJAS, FRIENDS OR STRANGERS] ("The facts are clear: the skills and earnings of recent immigrant waves are substantially below the skills and earnings of earlier waves."). As evidence, he points to the economic performance of immigrants relative to natives. See id. at 115-33. Yet the evidence also reveals that immigrants are becoming more skilled over recent decades; natives are simply becoming more skilled at an even greater rate. See George J. Borjas, The Economics of Immigration, 32 J. ECON. LITERATURE 1667, 1676-77 (1994) [hereinafter Borjas, Economics of Immigration].

In terms of the economic benefits for the private sector, this increasing divergence between the skill levels of immigrants and those of natives may be salutary rather than a cause for concern. Borjas presents a simple model in which "an immigrant flow that is very different from the native workforce ... maximizes the immigration surplus" by importing labor that complements rather than merely replicates the domestic workforce. Borjas, supra note 35, at 14. For the United States, which "presumably has a relatively skilled workforce," this model suggests that unskilled immigration 
If a country nevertheless chooses to protect a domestic market, standard trade theory, as well as international trade law, recommends tariffs over quotas. ${ }^{37}$ Both tariffs and quotas sacrifice gains from trade, but tariffs produce some revenue for the government, whereas quotas do not. Quotas make the right to import scarce and therefore valuable. This value derives from prices in the importing country that are higher than those available on the world market. The scarcity of quota rights create "quota rents," which an importing country could capture by selling the right to import. In practice, countries do not sell these rights, allowing importers to enjoy these quota rents. A tariff that restricts trade to a level equivalent to a quota will capture these quota rents in the form of tariff revenue. ${ }^{38}$

Similarly, if a country restricts immigration of labor, the optimal restriction would take the form of a tariff, not quotas. Quotas allow immigrants to keep the quota rents in the form of after-tax wages higher than those that prevail in alternative labor markets. ${ }^{39}$ A tariff

"maximizes the economic gains to natives by fully exploiting the production complementarities between immigrants and natives." Id.

Introducing capital into the model, however, may imply that skilled immigration produces more surplus for the United States than unskilled immigration if skilled labor is highly complementary with capital. See id. at 1417. Borjas concludes that "the immigration surplus might be larger when the immigration flow is composed exclusively of skilled workers." Id. at 19 . Borjas assumes, however, that quantitative restrictions force us to choose between skilled and unskilled workers. The policy that maximizes the immigration surplus would impose no restrictions on either type of immigration and let market demand determine how much of each type of labor we import.

${ }^{37}$ The GATT allows the use of tariffs but generally prohibits the use of quantitative restrictions on trade. See GATT, supra note 1,61 Stat. pt. 5, at A32, 55 U.N.T.S. at 224.

${ }^{3 s}$ See, e.g., KRUGMAN \& OBSTFELD, supra note 7, at 196 ("[T] he transfer of rents abroad makes the costs of a quota substantially higher than the equivalent tariff.").

${ }^{39}$ Julian Simon claims that this feature of immigration distinguishes the economics of immigration from the economics of trade: "[I]mmigrants tend to receive higher wages in the richer country to which they move. The immigrants benefit by the higher wages. But there is little or no immediate gain to the consumers in the new country analogous to the gains when goods are traded internationally." JULIAN $L$. SIMON, THE ECONOMIC CONSEQUENCES OF IMMIGRATION 338 (1989). The same statements, however, also apply to goods imported subject to quantitative restriction, especially if foreign firms in the exporting country receive the quota rights (as is often the case): the recipient of a quota right gains by receiving higher prices in the importing country, and there would be little gain to consumers in the importing country from a small increase in imports. On the other hand, a large increase in imports would produce larger gains for consumers by driving down prices, as would a large increase in immigration. Any difference in this regard between the effects of international trade in goods and those of international trade in labor services derives not from any fundamental difference in the underlying economic theory but rather from differences in the policy instruments used to restrict trade. 
could take the form of a charge for admission, which would be similar to quantitative restrictions with an auction to allocate the available visas to those potential immigrants. ${ }^{40}$ By selling visas, the country of immigration can capture the quota rents that would otherwise go to the immigrant. A tariff, however, could also take the form of a discriminatory income tax, rather than a payment up front, which would have the advantage that the immigrant would not need to have the resources to pay the tariff at the border. ${ }^{41}$ The immigrant could pay the tariff as extra income taxes withheld from income earned after immigration.

For a country with some market power, protectionist trade policies will have an effect on prices on the world market. ${ }^{42}$ In this case, standard trade theory predicts that the country can improve on free trade by imposing the "optimal tariff."

40 Julian Simon has advocated such an auction for immigration visas. See id. 32935; see also Gary S. Becker, Why Not Let Immigrants Pay for Speedy Entry?, BUS. WK., Mar. 2, 1987, at 20 (proposing that we retain the present admission system but add a separate new track for aliens willing to pay a flat fee).

11 See Chiswick, supra note 27, at 309 (proposing that the United States allow immigrants "to substitute an annual surcharge on their federal income tax as an alternative to [a] large entry fee"); Julian L. Simon, Auction the Right to Be an Immigrant, N.Y. TIMES, Jan. 28, 1986, at A25 (suggesting that the United States "allow 'buyers' to enter now and pay later together with income tax").

12 If the host country's trade policies can affect prices in its export markets, then its immigration policies can also affect these prices: liberalized immigration could reduce the costs of producing these exports and could thereby bring down the relative price of its exports. If so, then the benefits of liberalized immigration would go in part to foreign consumers of goods produced in the host country. It is more likely, however, that immigration would on balance turn the terms of trade in favor of the host country rather than against it, because trade tends to occur along the lines of comparative advantage.

For example, a country in which capital and technology are relatively abundant, like the United States, would tend to export goods intensive in these factors and import labor-intensive goods from countries in which labor is relatively abundant. Labor, which is relatively scarce in the United States, would immigrate and would tend to bring down the cost of producing importable goods more than the cost of exports. This effect would drive up the price of exports relative to imports and would therefore on balance shift the terms of trade in favor of the United States and against foreigners. See AVINASH DIXIT \& VICTOR NORMAN, THEORY OF INTERNATIONAL TRADE 149 (1980) (" $[\mathrm{A}]$ movement of labour to the labour-scarce, technologically advanced economy increases world output of the labour-intensive good by more than it increases world demand for that good. The rich country importing the labour-intensive good will therefore experience an improvement in the terms of trade following immigration."). These terms-of-trade effects would reinforce the gains for natives produced by liberalized immigration.

13 See, e.g., RICHARD E. CAVES \& RONALD W. JONES, WORLD TRADE AND PAYMENTS: AN INTRODUCTION 212-13 (4th ed. 1985). 
entail costly distortions, but it would also bring a gain to the importing country by driving down the price received by foreigners for the imported goods. ${ }^{44}$ The tariff drives a wedge between the higher prices prevailing in the importing country and the lower world prices paid to foreigners. The importing country can thus extract more of the gains from trade through tariff revenues. ${ }^{45}$

The same principles apply to imported labor. To the extent the United States can affect wages abroad, it has market power in the market for foreign labor, and it can gain by imposing a "tariff" on immigrant labor (that is, a discriminatory tax imposed only upon foreign workers). Under these conditions, the burden of a tariff would fall not only on employers and consumers but also on immigrant labor. To maximize national economic welfare, a country with some market power in the relevant market would raise taxes on migrants so as to drive their after-tax wages below what they would be in a world of free trade in labor. For a sufficiently small tariff, the gains from driving down foreign after-tax wages would exceed the costs of deterring valuable immigration. The government would capture these gains for the benefit of natives in the form of tariff revenue. ${ }^{45}$

"For a small tariff, the benefits would be large ("first-order") insofar as we import a large amount, so that any decrease in the price of imports would represent a large gain. The deadweight losses from the distortion of domestic consumption and production would be small ("second-order") for a small tariff. As we increase the tariff, however, the marginal benefits fall as imports fall, and the marginal costs increase as the tariff induces more costly distortions in domestic consumption and production. Furthermore, a reduction in imports becomes more costly to the public treasury as it loses larger tariffs per unit of import. The optimal tariff equates these marginal costs and benefits. The optimal tariff may vary from product to product, depending on circumstances in each product market.

The more elastic the supply of imports to the United States, for example, the less market power the United States has, and the lower the optimal tariff. For an elastically supplied import, a tariff would have an effect mainly on the quantity of imports and cause little fall in the price of imports. In the case of a perfectly elastic import supply, the United States would have no market power, and a tariff has no effect on the price paid to foreigners for imports. Then the incidence of the tariff would only be on buyers in the United States rather than on foreign sellers. Therefore, under these assumptions, the optimal tariff would be zero.

${ }^{45}$ A quota cannot extract any of these gains unless the quota rights are sold.

${ }^{16}$ The Jordan Commission proposed that those who employ foreign workers "pay a substantial fee," which would resemble a tariff, but this proposal would "ensure that the employer, and not the foreign worker, pays the fee." JORDAN COMM'N, supra note 15, at 112. From the perspective of the welfare of natives, however, it is perverse to place the burden of this tax on the employer. This tax would discourage the hiring of foreign workers and drive up the costs of goods and services to consumers without extracting tariff revenue from immigrants. 
The optimal tariff would vary depending on the type of labor, because different classes of labor would entail different market conditions. ${ }^{47}$ Thus, a discriminatory income tax would have an advantage over a uniform charge for admission, insofar as it could impose a tariff that is a function of income. By discriminating among immigrants in setting the tariff level, a country can not only capture quota rents but also charge a higher tariff on those who value immigration the most and thereby do a better job of extracting tariff revenue from immigrants. ${ }^{48}$

\section{B. External Effects of Immigration}

The foregoing analysis considered the economic effects of immigrant labor through the labor market alone. Immigrants, however, also have economic effects that are not internalized by private participants in that market. An immigration tariff, for example, yields benefits only for the public sector. Indeed, much of the debate over the economic effects of immigration has focused on the effects on the public sector. ${ }^{49}$ The presence of the public sector introduces external effects that must be included in the analysis. These effects include both benefits and costs, so that depending on the immigrant, it is possible for the net external effect to be either positive or negative.

${ }^{47}$ See Sykes, supra note 7, at 181 (“[T] for different types of immigrant labor, just as the optimal tariff varies across imported goods."). Given that immigration barriers segregate labor markets abroad, the optimal tariff can also vary depending on the country of origin.

${ }^{13}$ See id. (" $[E] v e n$ greater gains for original residents can be obtained through price discrimination. In the limit, if it were possible to observe the gains ... for each immigrant, the optimal tax on each (from the perspective of the original residents) would extract those gains but stop short of discouraging immigration altogether."); see also Bhagwati \& Srinivasan, supra note 27, at 218-19 (discussing the optimal tax on immigration and comparing this policy with a perfectly discriminatory tax).

${ }_{19}$ See, e.g., George J. Borjas \& Stephen J. Trejo, Immigrant Participation in the Welfare System, 44 INDUS. \& LAB. REI. REV. 195 (1991); REBECCA L. CLARK \& JEFFREY S. PASSEL, HOW MUCH DO IMMIGRANTS PAY IN TAXES? EVIDENCE FROM LOS ANGELES COUNTY (Program for Research on Immigration Policy, Population Institute, Urban Institute, Policy Discussion Paper PRIP-UI-26, 1993); JEFFREY S. PASSEL, IMMIGRANTS AND TAXES: A REAPPRAISAL OF HUDDLE'S "THE COSTS OF IMMIGRANTS" (Program for Research on Immigration Policy, Urban Institute, Policy Discussion Paper PRIP-UI-29, 1994); LOS ANGELES COUNTY INTERNAL SERVICES DEPARTMENT, IMPACT OF UNDOCUMENTED PERSONS AND OTHER IMMIGRANTS ON COSTS, REVENUES AND SERVICES IN LOS ANGELES COUNTY: A REPORT PREPARED FOR LOS ANGELES COUNTY BOARD OF SUPERVISORS (1992). For surveys of this literature, see Borjas, Economics of Immigration, supra note 36, at 1700-08, and Fix \& PASSEL, supra note 24, at 57-67. 
First, like natives, immigrants pay taxes, including income taxes, social security taxes, sales taxes, and property taxes. Immigrants and natives pay these taxes not only directly, but also indirectly through the effects of these taxes on prices. For example, property taxes paid nominally by landlords may be passed on to tenants through higher rents. Higher rents for commercial property may be passed on to consumers through higher prices. Similarly, immigrants also pay a share of the corporate income tax, whether as shareholders, employees, or consumers. All these taxes introduce an additional reason to value immigrants: they contribute tax revenues. Immigrants increase tax revenues by expanding the tax base. Once we take these external benefits into account, even in the absence of any discriminatory tax (that is, a tariff), the marginal benefit to a private employer of hiring a foreign worker will understate the marginal benefit to the "importing" country from the immigration of that worker.

Second, an immigrant also imposes external costs. For example, to the extent that an immigrant receives transfer payments from the government or has access to other public entitlement programs, these transfers will represent a cost to the country of immigration. Immigrants also gain access to public goods when they immigrate. To the extent they are pure public goods, like national defense, they feature nonrivalry in consumption. That is, immigrants can enjoy the public good without imposing any cost on natives. Immigrant access to other public goods, like parks or roads, however, may aggravate problems of congestion. Although free access to these goods would lead to congestion even in the absence of immigration, immigration increases the demand for these goods and presumably adds to the problem. Roads, for example, may become congested more frequently or more severely.

The ideal response to congestion problems is a "Pigouvian" access fee, which causes each person to internalize the negative externality imposed on others. ${ }^{50}$ Such a Pigouvian fee would not only optimize use of the public good, but also ensure that immigrant users (as well as native users) compensate the public treasury for any inconvenience they cause others. ${ }^{51}$ Such an access fee, however, may not always be

${ }^{30}$ See RICHARD CORNES \& TODD SANDLER, THE THEORY OF EXTERNALITIES, PUBLIC GOODS, AND GLUB GOODS 52 (1986); DAVD A. STARRETT, FOUNDATIONS OF PUBLIC ECONOMICS 51 (1988).

${ }^{51}$ Indeed, such a fee would overcompensate the public treasury. Because marginal congestion costs increase with the number of users, an access fee based on the marginal congestion cost will exceed the congestion cost imposed by all the inframarginal 
practical. If it is not feasible to exclude users from the public good in question, then we cannot charge for access. If we cannot use an access fee to internalize the congestion externality that immigrants can impose on each public good, however, we can still seek to do so imperfectly through taxes correlated with use of the good in question. Taxes could target users (both natives and immigrants) indirectly: for example, gasoline taxes target the users of public roads, and property taxes target those who use infrastructure in the local area. Local taxes could vary so as to discourage residence or economic activity in areas where infrastructure is subject to congestion. These taxes could reduce congestion somewhat, and even if they do not discriminate between natives and immigrants, they would also contribute to public coffers and thereby offer compensation to natives for the externalities that immigrants might impose by using congested infrastructure. ${ }^{52}$

Even after making appropriate use of tolls, gasoline taxes, property taxes, and other nondiscriminatory taxes and fees, we may find that some immigrants may impose congestion externalities in excess of the taxes they pay (both directly and indirectly). Those immigrants who pay the least in such taxes would be the most likely to impose net external costs on natives. To the extent that the taxes paid by immigrants do not cover the costs of congestion they impose and public entitlements they use, they would impose a net burden on the public sector. $^{53}$ Thus, the net effect of an immigrant on the public sector may be positive or negative, so that the immigrant's effect on the private sector through the labor market may understate or overstate the immigrant's effect on the economy of the country of immigration as a whole.

Thus, because skilled workers tend to have higher incomes and to pay more in taxes, it is in the national economic interest to promote their immigration. As long as they make a positive contribution to the public sector, there is in general no economic justification for excluding these immigrants. Therefore, quantitative or other protectionist restrictions on their immigration should be eliminated.

users. If each user pays a fee equal to the marginal congestion costs, then the total revenues will exceed the total congestion costs.

${ }^{32}$ See SIMON, supra note 39, at 153 ("[A] large part of public capital is built with borrowed money. And with the taxes they pay, new dwellers help cover the service of this debt to an extent that the new dweller is not a burden on old dwellers in this respect.").

${ }^{35}$ See George J. Borjas, Tired, Poor, on Welfare, in ARGUING IMMIGRATION 76, 77 (Nicolaus Mills ed., 1994) (arguing that because "a larger population will lead to more crowded freeways and parks, schools and hospitals," immigrants "should be assigned a user fee for them"). 
To the extent that unskilled workers tend to have lower incomes, they tend to pay less in taxes and to take greater advantage of public entitlement programs. Thus, the benefits flowing to the national economy from their immigration may be reduced and may indeed be negative at the margin. A net negative effect through the public sector introduces a potential justification for restricting their immigration. The international trade perspective, however, suggests that if some immigrants have a negative effect on the public sector, the optimal response is not nontariff restrictions on immigration, such as quotas. Rather, the appropriate response is fiscal. In such cases, we can use a tariff, that is, a tax imposed only on immigrants, to restrict access to all our public goods and public entitlements. If we seek to maximize the welfare of natives and give no weight to the welfare of immigrants, then we would prefer tariffs over quotas because tariffs shift wealth from immigrants to natives in the form of tax revenues. ${ }^{54}$

\section{The Optimal Tariff on Unskilled Immigrants}

Suppose unskilled immigrants would have a negative effect on the public sector in the absence of a tariff, and consider the optimal tariff for natives to levy on them. A tariff would increase the contribution of these immigrants to the public coffers as well as discourage their immigration. We could, for example, impose a tariff high enough to ensure that the marginal immigrant's net effect on the public sector would be zero. This Pigouvian tariff can reduce immigration to a level that equates the marginal benefits to natives with the marginal costs imposed on natives by immigration, including congestion costs. $^{55}$ Immigration would expand only to the point where the private sector no longer derives any surplus from hiring another immigrant. Because the tariff would ensure that the marginal immigrant

${ }^{54}$ Contrast this policy with that suggested by Borjas, supra note 35 , at 12-19. Borjas takes an overall quota on total immigration as given. He assumes implicitly that this quota is fixed, applies to all classes of labor, and binds regardless of how these visas are allocated among classes. Borjas suggests that to maximize the welfare of natives, the United States should allocate the visas subject to this quota to skilled immigrants rather than unskilled immigrants. The analysis in this paper assumes instead that we can use tariffs rather than quotas and indicates that the policy that would maximize the welfare of natives would not impose any quotas on immigration. Only less skilled immigration would be restricted, and this restriction would take the form of tariffs instead of quotas.

${ }^{33}$ If marginal congestion costs rise with the level of immigration, then we would expect this tariff to overcompensate natives for the immigrants' total contribution to congestion costs. 
would impose no net external cost, this outcome would also be optimal for the domestic economy as a whole. ${ }^{56}$ This tariff would eliminate any immigration expected to have a negative effect on national economic welfare. The resulting Pigouvian level of immigration would be first-best from the perspective of maximizing the welfare of natives.

Although this level of immigration is efficient in this sense, it will nevertheless be in the interest of natives to raise the tariff still higher. A tariff above Pigouvian levels will reduce immigration below optimal levels, but will in general produce gains sufficient to justify this distortion. These gains derive from two different sources. First, the foregoing analysis has not considered the need to raise tax revenues, which will justify higher tariffs. Second, to the extent that the country of immigration has market power, tariffs will drive down the after-tax wages of immigrants.

Consider the first reason to raise tariffs above Pigouvian levels. Governments need revenues to finance the provision of public goods, but most taxes they use to raise revenues will cause costly distortions in the economy. These distortions imply an "excess burden" of taxation: taxes impose costs on the private sector that exceed the revenue collected by the government. ${ }^{57}$ An optimal tax system seeks to minimize the excess burden associated with raising any given amount of tax revenue. Because tariff revenue raised from immigrants would allow distortionary taxes elsewhere in the economy to be reduced, optimal-tax considerations would call for a tariff even if it causes some distortion in the level of immigration. An optimal tariff would be higher than that which induces the optimal quantity of immigration. Thus, the optimal tariff would assure that each immigrant makes on balance a net positive contribution to the public sector.

The optimal tariff would exceed Pigouvian levels even in the absence of any market power. Suppose the supply of unskilled labor is perfectly elastic, so that a tariff would have no effect on the after-tax wage of immigrants. Instead, the burden of the tariff would fall on the employer, who must pay the tariff on top of the immigrant's wage. Although there is no "market power" rationale for a tariff in this case,

${ }^{36}$ See Krauss \& Baumol, supra note 27, at 44 (describing how a tax on guest workers "would equate the marginal private cost of guest workers with their marginal social cost and lead to an optimal use of imported labor by the host country").

${ }^{57}$ See, e.g., DAVD N. HMMAN, PUBLIC FINANCE: A CONTEMPORARY APPLICATION OF THEORY TO POLICY 384 (4th ed. 1993). 
for all the reasons discussed above, the optimal tariff would be high enough to distort immigration below the first-best level.

Suppose the supply of unskilled labor is less than perfectly elastic. The less elastic the supply of immigrant labor, the more a tariff causes a fall in immigrant after-tax wages rather than a fall in the quantity of immigration. This inelasticity would present two reasons to raise the tariff still higher. First, this smaller distortion in immigration would militate in favor of a higher tariff under optimal-tax principles because the excess burden imposed on employers would be lower.

Second, to the extent that a tariff drives down the after-tax wage of immigrants, the burden of the tariff would fall on immigrants, and this portion of the tariff revenue represents a net gain to the economic welfare of natives rather than a transfer from employers to the public treasury. Because we assign no weight to the welfare of immigrants (by assumption for the purposes of this discussion), the fall in their after-tax wages represents an unambiguous increase in national economic welfare. The more inelastic the supply of immigrant labor, the stronger this effect, and the higher the optimal tariff. Thus, the presence of market power presents a second rationale for higher tariffs that is distinct from the optimal-tax rationale: even if distortionary taxes were unnecessary to finance public goods, the transfer from immigrants to public coffers would represent a gain for natives that would justify a distortionary tariff.

Thus, for immigrants who would otherwise have a negative economic effect on the public sector, the optimal tariff is unambiguously positive. The larger the (nondiscriminatory) taxes paid by an immigrant, however, the more valuable the immigrant will be for public coffers, and the less inclined we should be to levy a positive tariff in addition to these other taxes. Indeed, for skilled immigrants who would on balance have a sufficiently positive economic effect on the public sector, the optimal tariff could well be zero or even negative. ${ }^{58}$

\section{The Optimal Tariff on Skilled Immigrants}

Consider skilled immigrants who have a net positive effect on the public sector even in the absence of a tariff. To analyze how the external net benefits associated with these immigrants affect the calculation of the optimal tariff, suppose first that the country of immigra-

${ }^{38}$ Sykes observes that "if immigration yields sufficiently large positive externalities, the optimal tax might be negative (a subsidy)," but he does not explore this idea any further. Sykes, supra note 7, at 181. 
tion has no market power: the supply of immigrants is perfectly elastic. In this case, there is no "market power" basis for a positive optimal tariff, because taxes do not drive down the wages received by immigrants. Instead, the incidence of taxes falls only upon employers, who must pay higher wages as a result of taxes.

Given these assumptions, it is likely to be in the national economic interest to discriminate in favor of skilled immigrants in our income tax rates. The fact that these immigrants make net positive contributions to the public sector implies that their tax payments are high enough to distort their immigration below first-best levels. Taxes on immigrants in excess of Pigouvian levels produce deadweight loss by making immigrant labor too costly for employers. Lower taxes would expand immigration toward the first-best level, which would bring a gain for the economy as a whole.

A complete analysis, however, would also consider the need to raise tax revenues. Taking these effects into account still points toward lower tax rates on immigrant labor if the supply of this labor is perfectly elastic. Optimal-tax theory prescribes lower tax rates on markets where supply or demand is more elastic, so as to minimize the excess burden of taxation. ${ }^{59}$ Thus, suppose that skilled immigrants pay enough in taxes other than income taxes (such as sales taxes and property taxes) to cover any external costs they impose on natives. Optimal-tax theory would prescribe higher income taxes on natives as long as the supply of their labor is less elastic than the perfectly elastic supply of immigrant labor. Lower taxes on immigrants would increase immigration, which would generate new tax revenues as well as reduce the cost of labor for employers. Under these circumstances, the optimal tariff is unambiguously negative.

Suppose instead, that the supply of immigrant labor is less than perfectly elastic. If the supply of immigrant labor is upward-sloping, then the optimal tariff is no longer unambiguously negative. Inelasticity of immigrant labor supply introduces two considerations that would cut in favor of higher tariffs.

First, "market power" considerations militate in favor of a positive tariff on immigrants. These considerations tend to be weak, however, when nondiscriminatory taxes are already high. To the extent we have market power, income and wage taxes not only discourage immigration but also drive the after-tax wages of immigrants downward.

${ }^{39}$ See, e.g., ANTHONY B. ATKINSON \& JOSEPH E. STIGLITZ, LECTURES ON PUBLIC ECONOMICS 368-69 (1980); HYMAN, supra note 57, at 385-87. 
Both of these effects undercut the case for a positive tariff. The more immigrants pay in these other taxes, the greater the marginal cost of a tariff (we lose more tax revenues when immigration falls) and the smaller the marginal benefit (there are fewer immigrants whose wages will fall).

Second, the more inelastic the supply of immigrant labor, the less optimal-tax considerations militate in favor of negative tariffs. These considerations would still militate in favor of lower taxes on immigrants, however, as long as the supply of immigrant labor is more elastic than the supply of domestic labor. We would expect this condition to hold over the relevant range of wages: the supply of domestic labor is elastic largely because native workers have the option of leaving the labor force, whereas immigrants have not only the option of leaving the labor force but also the option of remaining in their native countries and accepting employment there. Natives of a country of immigration are less likely than immigrants to respond to taxes by leaving (or failing to enter) the domestic labor market, because each worker is inclined, ceteris paribus, to remain in the worker's native country. ${ }^{\text {(0) }}$ Immigrants by definition have self-selected as workers willing to move, given the international differences in wage levels, but the costs of moving, both psychic and financial, imply that many would also decide not to move if taxes reduce the rewards to migration. ${ }^{61}$ Thus, the decision of each individual immigrant to supply la-

${ }^{60}$ See RONALD G. EHRENBERG \& ROBERT S. SMITH, MODERN LABOR ECONOMICS: THEORY AND PUBLIC POLICY 331 (5th ed. 1994) ("[A] large part of the costs of migration are psychic, the losses associated with giving up friends, community ties, and the benefits of knowing one's way around."); MICHAEL WALZER, SPHERES OF JUSTICE: A DEFENSE OF PLURALISM AND EQUALITY 38 (1983) ("Human beings ... move about a great deal, but not because they love to move. They are, most of them, inclined to stay where they are unless their life is very difficult there."); Carens, supra note 26, at 270 ("They normally feel attached to their native land and to the particular language, culture, and community in which they grew up and in which they feel at home.").

${ }^{61}$ Even free immigration policies probably would not eliminate international differences in wages. The financial and psychic costs of migration would drive a wedge between domestic and foreign wages, just as transportation costs can sustain differences in prices among different geographic markets. Consider Puerto Rico, for example, which is a territory of the United States. Puerto Ricans are U.S. citizens and are thus free to move to the U.S. mainland. See Fernando A. Ramos, Out-Migration and Return Migration of Puerto Ricans, in IMMIGRATION AND THE WORK FORCE: ECONOMRC CONSEQUENCES FOR THE UNITED STATES AND SOURCE AREAS 49 (George J. Borjas \& Richard B. Freeman eds., 1992) [hereinafter IMMIGRATION AND THE WORK FORCE]. Yet, despite the free mobility of labor, large real-wage differentials for unskilled workers persisted between Puerto Rico and the U.S. mainland for decades until Puerto Rico's minimum wage was brought up to U.S. levels in 1983. See Alida J. Castillo-Freeman \& Richard B. Freeman, When the Minimum Wage Really Bites: The Effect of the U.S.-Level Mini- 
bor to the country of immigration is likely to be more sensitive to taxes than the decision of natives to supply labor to the domestic labor market.

Furthermore, we would expect the elasticity of the supply of immigrant labor to be particularly large if the immigrant labor is drawn from a world labor market that is large relative to the domestic labor market. Given the size of the world labor market, we would in general expect the supply of immigrant labor to be quite elastic. Thus, optimal-tax considerations not only militate in favor of a negative tariff, but these considerations may also be significant. Furthermore, the elasticity of immigrant labor supply also suggests that "market power" considerations in favor of positive tariffs may be weak.

Thus, the optimal tariff may be positive, but without precise information on elasticities and other data, the optimal tariff may also be negative. It is especially likely to be negative for classes of immigrants who already bear a high tax burden, because they are attractive from a fiscal perspective. ${ }^{62}$ For skilled immigrants expected to pay a large amount in income and other taxes, it is likely to be in the national interest to offer lower tax rates than those imposed on natives, in order to encourage the immigration of more taxpayers.

mum on Puerto Rico, in IMMIGRATION AND THE WORK FORCE, supra, at 177. Similarly, the free movement of labor within the European Union has failed to eliminate all wage disparities. See Johnson, supra note 4, at 972-73 (noting that "those who predicted that ... free movement ... would result in large-scale emigration from member countries with floundering economies were proven wrong," in spite of "wage disparities among the European Union's member nations" (footnotes omitted)). Any nontariff barriers to migration would only reinforce the tendency for workers in countries of immigration to enjoy higher wages than similar workers in countries of emigration.

${ }_{62}$ Furthermore, to the extent that other countries of immigration are eager to attract these immigrants, they may have more options than less skilled immigrants. See BORJAS, FRIENDS OR STRANGERS, supra note 36, at 199-217 (reviewing the competition among countries of immigration for skilled immigrants and concluding that the United States has not fared well relative to Australia and Canada). The migration of less skilled workers may be more likely to be blocked by protectionist quotas in other countries of immigration. Thus, the supply of highly skilled immigrants to the United States may be more elastic in the relevant range than the supply of less skilled immigrants compared to the supply of similarly skilled native workers. The net supply curve for labor immigrating to the United States would reflect the subtraction of the net labor demand curves of all other countries that offer these workers access to their national labor markets. On the other hand, in a zero-tariff free-trade equilibrium, the United States might employ a larger fraction of the world supply of highly skilled labor than it would of the world supply of less skilled labor. If so, this fact would make it ambiguous whether the supply of highly skilled immigrants to the United States is more elastic than the corresponding supply of less skilled immigrants compared to the supply of similarly skilled native workers. 


\section{E. Immigration of Nuclear Families}

For simplicity of analysis the foregoing discussion has treated immigrants as individual workers only. In reality, workers may often be reluctant to migrate without bringing close family members with them. What would be the optimal immigration policy regarding the admission of an immigrant worker's family? As long as the psychic and economic benefits of family unification (measured by the immigrants' willingness to pay for these benefits) exceed the congestion costs the additional immigrants would impose on natives, it will be optimal to allow workers to bring their relatives. These benefits are likely to be sufficiently large for a worker's immediate family (spouses and dependent children), who derive large benefits from cohabitation. Given the large benefits of keeping nuclear families united, the total benefits to the immigrant family would probably exceed any net external costs that these relatives would impose on natives, even after accounting for congestion costs.

With appropriate fiscal policies, natives can gain from the admission of these relatives. First, the immigrant household will pay more in sales and other taxes. Second, if these extra taxes are insufficient to create a net positive external effect of these additional immigrants, the immigrant family would be willing pay a higher tariff to compensate natives for any increase in external costs, such as congestion costs and any net transfers. By charging a higher tariff, natives can capture some of the surplus produced by family unification.

\section{F. Future Generations}

The foregoing analysis has focused only on the effects of immigration on the current generation of natives. Extending the analysis to include the effects on the descendants of these natives, however, is unlikely to change our conclusions significantly. Consider how immigration today will affect the welfare of future generations.

The children and other descendants of the immigrant workers we admit will produce the same type of gains from trade in the labor market that the immigrants themselves will bring. These positive effects upon the private sector offer no reason to adopt more restrictive immigration laws. The only possible negative effect would come through the public sector. Is there any reason to think that immigration will produce negative external costs on future generations of natives? 
To answer this question, we must first address the issue of whose welfare counts in our analysis of future social welfare. The descendants of immigrants, after all, will be natives, and on that score would seem just as entitled to our concern as those who are currently natives or their descendants. In this spirit, the Fourteenth Amendment of the U.S. Constitution confers U.S. citizenship on anyone born in the United States. ${ }^{63}$ The main purpose of this amendment was to establish the citizenship of blacks, which the Supreme Court had put in doubt in Dred Scott v. Sandford, $\dot{d}^{64}$ but its effect is to create a general rule of universal citizenship by birth. ${ }^{65}$ From this perspective, if the descendants of immigrants are better off than they would be had their forebears not immigrated, then the improvement in their welfare would count as an additional benefit of immigration.

Nativists may balk, however, at counting this effect as a benefit. They may consider the descendants of immigrants less worthy of our concern than the descendants of natives. ${ }^{60}$ Nativists may object that because we are formulating immigration policy, we are deciding whether these descendants will be natives. In evaluating alternatives, therefore, we cannot assume that their welfare counts. Excluding their welfare may underscore the discriminatory nature of nativism,

${ }^{63}$ See U.S. CONST. amend. XIV, § 1 ("All persons born or naturalized in the United States, and subject to the jurisdiction thereof, are citizens of the United States and of the State wherein they reside." ).

${ }^{a} 60$ U.S. (19 How.) 393 (1857).

${ }^{65}$ See United States v. Wong Kim Ark, 169 U.S. 649, 676 (1898); THOMAS A. ALEINIKOFF ET AL., IMMIGRATION: PROCESS AND POLICY 993 (3d ed. 1995). Nevertheless, bills pending in Congress would seek to deny birthright citizenship to the children of undocumented immigrants and of nonimmigrant alien visitors. See House Panels Hear Testimony on Birthright Citizenship, 73 INTERPRETER RELEASES 97 (1996); see also PETER H. SCHUCK \& ROGERS M. SMITH, CITIZENSHIP WITHOUT CONSENT: ILLEGAL ALIENS IN THE AMERICAN POLITY (1985) (proposing a reinterpretation of the Fourteenth Amendment to allow Congress to deny birthright citizenship to the children of undocumented immigrants and of nonimmigrant alien visitors). Governor Pete Wilson of California and others have called for a Constitutional amendment that would prevent the children of undocumented immigrants from acquiring U.S. citizenship by birth. For a critique of such proposals, see Note, The Birthright Citizenship Amendment: A Threat to Equality, 107 HARV. L. REV. 1026 (1994). Since the triumph of liberalism over feudalism, or at least since the abolition of slavery, these proposals to shift our focus toward lineage as the factor determining a person's legal status might seem anachronistic. See Carens, supra note 26, at 252 ("Citizenship in Western liberal democracies is the modern equivalent of feudal privilege-an inherited status that greatly enhances one's life chances. Like feudal birthright privileges, restrictive citizenship is hard to justify when one thinks about it closely.").

${ }^{66}$ This type of nativism may strike us as particularly unseemly, because it discriminates between future natives based on how recently their forebears immigrated and thus seems at odds with a commitment to the equal moral worth of all natives. 
but it is consistent with a strictly nativist view of social welfare. Suppose we adopt this nativist measure of social welfare and consider only the welfare of the descendants of those who are currently natives.

This definition of social welfare, however, still leaves some conceptual problems. Because some immigrants and some of their descendants will marry some of those who are currently natives and some of their descendants, the distinction between these two populations will disappear over time. The higher the rate of intermarriage between these groups, the more rapidly this distinction will erode. ${ }^{67}$ Eventually, given the passing of a sufficient number of generations, the terms "descendants of immigrants whose admission we are contemplating" and "descendants of those who are currently natives" will describe virtually the same population, because nearly everyone will have at least one ancestor who is currently a native and at least one ancestor who immigrated subsequently.

Thus, two effects of immigration on the descendants of those who are currently natives-and the main effects in the long term-will be to increase their number and to change their identities. Because they will be less likely to marry one another, there will be a larger population of descendants of those who are currently natives. This effect requires us to define our measure of social welfare more precisely. If we adopt a utilitarian measure of social welfare, for example, we must specify whether we take our measure of social welfare to be total utility or average utility. If we adopt the principle of total utility, then an increase in population, ceteris paribus, would represent an increase in social welfare. To avoid "stacking the deck" in favor of immigration, suppose we adopt a social welfare criterion based on average wealth rather than total wealth. From this perspective, the main cost of population growth would be to increase per capita congestion costs for public goods that are subject to congestion on the plausible assumption that marginal congestion costs rise with population. On the other hand, there would also be some economies of scale: a larger population could produce pure public goods at a lower cost per capita.

${ }^{67}$ This rate may be high even if the rate of intermarriage across ethnic or racial groups is low: if both the current native population and the immigrant stream include people from all ethnic and racial groups, as is true for the United States, then intermarriage may occur frequently between these two populations within each ethnic or racial group. This phenomenon is especially likely for future generations, who are unlikely to discriminate among potential spouses based on how recently their forebears immigrated. 
Our calculus would also include the costs imposed and the benefits conferred by the descendants of immigrants upon the descendants of those who are currently natives, but only in the short term, while these populations remain distinct. The benefits would include the gains from trade in the labor market and the taxes paid by the descendants of immigrants. The costs would include entitlements consumed by these descendants. ${ }^{\text {.s }}$

To derive the optimal immigration policy, we would add up all these costs and benefits in economic terms on a per capita basis, discounting each cost and benefit to a net present value. ${ }^{69}$ With respect to each class of immigrant, we would estimate the expected total net present value associated with each immigrant worker, which would be an average calculated in the face of uncertainty. ${ }^{70}$ We would count this expected value as one component of an immigrant's external effects. The only implication for the optimal immigration policy, then, would be an adjustment in the optimal tariff.

There would appear to be no reason to presume that these effects would always call for a higher tariff. If these future effects produce a positive value for immigration, then a lower tariff may be optimal. Given the correlation between an immigrant's income and the income of the immigrant's descendants, we might generally expect skilled immigration to have a positive net effect through future generations, whereas unskilled immigration might have a negative net effect. $^{71}$ If so, then these effects serve to reinforce the conclusions derived above: the optimal tariff on unskilled labor is positive, but the optimal tariff on skilled labor may be negative. On the other hand, one would expect the descendants of immigrants to assimilate and to obtain language and other skills that enable them to fare better than their parents in terms of economic performance. The available empirical evidence suggests that the children of immigrants do tend to

s Insofar as the descendants of immigrants acquire citizenship by birth, they may have greater access to public entitlements than their immigrant forebears.

${ }^{\omega}$ For a helpful discussion of the role of discounting in cost-benefit analysis, see John Broome, Discounting the Future, 23 PHIL. \& PUB. AFF. 128 (1994).

${ }^{70}$ After calculating the per capita effect on the descendants of those who are currently natives, to calculate the total value associated with each immigrant, we need to multiply this per capita value with the number of people affected. To apply a criterion based on average wealth, however, the number must be fixed exogenously. Suppose we choose the number of descendants that natives would have in the absence of any immigration.

"See Borjas, Economics of Immigration, supra note 36, at 1711-12 (discussing evidence that immigrant skill differentials persist over generations). 
outperform their parents on average. ${ }^{72}$ This fact would tend to undercut a presumption of a negative future effect of unskilled immigration.

In sum, there seems to be little reason to expect that these considerations would have an important effect on the optimal tariff. Most of these effects occur in the distant future. Given that we must discount all these effects to a net present value, their total would probably be relatively small.

\section{G. Avoiding External Costs}

A country of immigration may implement a positive tariff on immigration not only through a tax on immigrants but also through restrictions on immigrant access to public entitlement programs. ${ }^{73}$ Either form of tariff could improve the effect of immigration on the economic welfare of natives. The national economic interest, however, would not call for the elimination of immigrant access to public benefits in all cases. To maximize the economic welfare of natives, we would at least allow immigrants access to public entitlements when the benefits to natives from such access exceeds the costs of providing the access. Moreover, to the extent we allow still broader access to these programs, we can charge a correspondingly higher tariff to cover the additional cost imposed on the public sector.

We provide many public services that serve our own interests and not simply the interests of the recipients of those services. For example, the education of immigrant children is likely to have benefits for natives that exceeds the costs of providing access to public schools. ${ }^{74}$ Investment in the human capital of immigrant children provides them with skills that will yield external benefits in the future when they enter the labor market. ${ }^{75}$ As skilled workers, they will have

${ }^{72}$ See id. at 1711 (discussing the convergence of skill differentials over generations and noting that "the empirical evidence... indicates that second-generation workers do experience a 'jump' in their earnings capacity").

${ }_{73}$ See Krauss \& Baumol, supra note 27 , at $37,44-45$ (discussing a special tax and exclusion from welfare benefits as alternative responses to the same problem).

${ }^{74}$ See Borjas, Economics of Immigration, supra note 36, at 1708 ("These costs ... must be contrasted with the benefits of having a more educated work force later on in the life cycle.").

${ }^{75}$ As the U.S. Supreme Court understood in Plyler v. Doe, 457 U.S. 202 (1982), this reasoning applies to immigrants whether they are legal or undocumented. The Court held that states may not deny undocumented immigrant children the free public education that they provide to U.S. citizens and legal immigrants. The Court stressed that "education provides the basic tools by which individuals might lead economically pro- 
higher incomes and pay more in taxes than they would without an education. $^{76}$ Other programs designed to support investments in human capital may yield similar benefits for natives by creating a more skilled immigrant labor force. Thus, while Congress enacted new limits on the access of future immigrants to federal "meanstested" public benefits as part of the Personal Responsibility and Work Opportunity Reconciliation Act of 1996, this welfare legislation also preserved their access to specific programs related to education and training. ${ }^{77}$

The provision of some publicly subsidized health care could also yield benefits for natives exceeding its costs. ${ }^{78}$ Immunizations, for ex-

ductive lives to the benefit of us all." Id. at 221. Even the four dissenters conceded that "it is senseless for an enlightened society to deprive any children-including illegal aliens-of an elementary education" and that "it would be folly-and wrong-to tolerate creation of a segment of society made up of illiterate persons, many having a limited or no command of our language." Id. at 242 (Burger, C.J., dissenting) (footnote omitted); see Sykes, supra note 7, at 172 ("Plyler v. Doe... need not be contrary to the pursuit of the national advantage."). Despite these considerations, the voters of California in November 1994 passed Proposition 187, which would deny undocumented aliens access to various public services, including education. See Proposition 187, $\$ 7$ (codified at CAL. EDUC. CODE $\S 48215$ (West 1997)). A federal court, citing Plyler $v$. Doe, has since enjoined implementation of this provision. See League of United Latin American Citizens v. Wilson, 908 F. Supp. 755, 785 (C.D. Cal. 1995) ("[D]enial of a public education based on the immigration status of the child or the child's parent or guardian conflicts with and is preempted by federal law as announced by the Supreme Court in Plyler."). Although the House of Representatives subsequently passed legislation that would allow states to exclude undocumented children from public schools, President Clinton threatened to veto any bill including this provision. See Showdown Looms over Public Education Measure in Immigration Legislation, 73 INTERPRETER RELEASES 817, 817 (1996). Faced with this threat, Republicans in Congress deleted this provision from the immigration bill eventually enacted into law. See Eleventh-Hour Agreement Folds Immigration Bill into Omnibus Spending Measure, 73 INTERPRETER RELEASES 1281, 1282 (1996).

${ }^{76}$ Indeed, from this perspective, countries of immigration "free ride" on the investments that countries of emigration have made in the education of migrants. See Borjas, Economics of Immigration, supra note 36, at 1708 ("[I]mmigrants who enter the United States after they complete their education import 'free' human capital into the United States."). The host country derives the external benefits of the immigrant's skills without paying for the creation of that human capital. See Sykes, supra note 7, at 172 (" $[T]$ his observation suggests why countries might seek to restrict emigration to promote the national advantage, but does nothing to justify restrictions on immigration.").

7 See Personal Responsibility and Work Opportunity Reconciliation Act of 1996, Pub. L. No. 104193, sec. 403, 110 Stat. 2105, 2265-66 (to be codified at 8 U.S.C. $\$ 1613$ ) (denying future immigrants access to "any Federal means-tested public benefit for a period of 5 years" but exempting school lunch benefits, certain programs of student assistance, certain elementary and secondary education programs, Head Start benefits, and Job Training Partnership Act benefits).

${ }^{78}$ For these reasons, it is doubtful that Proposition 187, see Proposition 187, $\$ 6$ (codified at CAL. HEALTH \& SAFETY CODE $\$ 130$ (West 1997)), which would exclude undocumented aliens from publicly funded health care, is in the interest of U.S. natives. See 
ample, provide benefits not only to those immunized, but also to all others, because immunizations reduce the risk that infectious diseases will spread. $^{79}$ Natives have a similar interest in the diagnosis and treatment of immigrants with communicable diseases. Thus, while the welfare legislation enacted in 1996 restricts immigrant access to Medicaid and other federal public benefits, it preserves access to some public health assistance for immunizations and for the testing and treatment of communicable diseases. ${ }^{80}$

Prenatal care for pregnant immigrant women may be another example, because it yields benefits for babies who will be natives when born. To the extent that natives enjoy a public entitlement to health care, these babies could impose costs on other natives if they are born sickly or prematurely. If prenatal care efficiently prevents these later costs, then it is in the interest of natives to provide such preventive care. Nevertheless, the 1996 welfare legislation does not exempt prenatal care from its new restrictions.

Other public entitlements for immigrants may be less likely to yield benefits for natives. Some public entitlements are pure transfers: they serve only to redistribute income and not to subsidize the provision of a public good. Natives may gain, for example, by denying immigrants access to transfers, such as the earned income tax credit in the United States, which provides cash payments to lowincome workers. ${ }^{81}$ A positive tariff on immigrant labor can take the form of an income tax credit provided to all citizens but denied to immigrants, combined with an otherwise nondiscriminatory income tax system.

The objective of reducing the burden immigrants impose on natives through the public sector underlies restrictions on the access of aliens to various entitlement programs. Under U.S. law, for example, even before Congress enacted new restrictions in 1996, aliens were

Kevin R. Johnson, Public Benefits and Immigration: The Intersection of Immigration Status, Ethnicily, Gender, and Class, 42 UCLA L. REV. 1509, 1568-70 (1995) (discussing these and other costs of Proposition 187).

${ }^{79}$ See Stephen H. Legomsky, Immigration, Federalism, and the Welfare State, 42 UCLA L. REV. 1453, 1465 (1995) ("Prohibiting publicly funded facilities from immunizing immigrants against ... contagious diseases would pose ... dangers to public health.").

${ }^{80}$ See Personal Responsibility and Work Opportunity Reconciliation Act, sec. 403 (c) (2) (E), 110 Stat. at $2265-66$ (to be codified at 8 U.S.C. $\$ 1613$ (c)(2)(E)). The legislation preserves similar access for undocumented immigrants. See id. sec. 401 (b) (1) (C), 110 Stat. at 2261 (to be codified at 8 U.S.C. $\$ 1611$ (b)(1)(C)).

${ }^{81}$ For an examination of the earned income tax credit, see Anne L. Alstott, The Eamed Income Tax Credit and the Limitations of Tax-Based Welfare Reform, 108 HARV. L. REV. 533 (1995). 
generally ineligible for most public entitlements, including Medicaid, Aid to Families with Dependent Children ("AFDC"), and food stamps, unless they had been lawfully admitted for permanent residence. ${ }^{82}$ Thus, not only undocumented immigrants but also aliens admitted to the United States temporarily as nonimmigrants, including temporary workers, were ineligible for most public benefits because they were not lawfully admitted for permanent residence. ${ }^{83}$ The recently enacted welfare legislation expands the range of public benefits from which nonimmigrants and undocumented immigrants are generally excluded: with only narrow exceptions, these aliens are ineligible for "any Federal public benefit."

The same legislation also adds extensive new restrictions on the access of other aliens, including even legal permanent residents, to federal entitlement programs. In particular, an alien admitted for permanent residence after enactment of the new law is ineligible for "any Federal means-tested public benefit for a period of 5 years beginning on the date of the alien's entry into the United States," with

${ }^{82}$ See 7 U.S.C. $\$ 2015(f)$ (1994) (limiting the eligibility of aliens for food stamps); 42 U.S.C. $\$ \S 602(a)(33), 1396 b(v), 1436$ a (1994) (limiting the eligibility of aliens for AFDC benefits, Medicaid benefits, and public housing assistance, respectively); DAVID CARLINER ET AL., THE RIGHTS OF ALIENS AND REFUGEES 214 (1990); Sykes, supra note 7, at 189,191 . For a survey of these restrictions on alien access to public entitlements, see Richard A. Boswell, Restrictions on Non-Citizens' Access to Public Benefits: Flawed Premise, Unnecessary Response, 42 UCLA L. REV. 1475, 1487-97 (1995).

. ${ }^{83}$ Aliens other than permanent residents, however, may be eligible for the earned income tax credit if they are resident aliens for tax purposes. See 26 U.S.C. $\$ 32(c)(1)(E)$ (1994). A lawful permanent resident is a resident alien for these purposes, but other aliens may also be resident aliens if they meet certain conditions. See id. $\$ 7701$ (b)(1)(A). For example, if an alien's presence in the United States satisfies the "substantial presence" test set forth in the statute, see id. $\$ 7701(\mathrm{~b})(3)$, then the alien is treated as a resident.

${ }^{B s}$ Personal Responsibility and Work Opportunity Reconciliation Act, sec. 401 (a), 110 Stat. at 2261 (to be codified at 8 U.S.C. $\$ 1611$ (a)). The statute defines "Federal public benefit" very broadly, including not only "any retirement, welfare, health, disability, public or assisted housing, postsecondary education, food assistance, unemployment benefit, or any other similar benefit for which payments or assistance are provided ... by an agency of the United States or by appropriated funds of the United States" but also "any grant, contract, loan, professional license, or commercial license provided by an agency of the United States or by appropriated funds of the United States." Id. sec. 401 (c)(1), 110 Stat. at 2262 (to be codified at 8 U.S.C. $\$ 1611(\mathrm{c})(1)$ ). The law also makes explicit the exclusion of aliens from the earned income tax credit if they are not authorized to work in the United States. See id. sec. 451, 110 Stat. at 2276-77 (to be codified at 26 U.S.C. $§ 32$ ). Thus, undocumented immigrants are ineligible for the earned income tax credit. Furthermore, the new law also prohibits states from providing "any State or local public benefit" to undocumented aliens unless the state subsequently enacts a law that "affirmatively provides for such eligibility." Id. sec. 411,110 Stat. at $2268-69$ (to be codified at 8 U.S.C. $\$ 1621$ ). 
only narrow exceptions. ${ }^{85}$ Furthermore, the new law makes permanent resident aliens, including current recipients already admitted to the United States, ineligible for food stamps and for Supplemental Security Income, without regard to length of residence in the United States, also with only narrow exceptions. ${ }^{86}$ Finally, the new law also permits states to exclude permanent resident aliens, including current recipients already admitted to the United States, from benefits under other federal programs, including Medicaid, and under state programs, without regard to length of residence in the United States. ${ }^{87}$ The law explains that Congress enacted these new rules to ensure that "aliens not burden the public benefits system." ${ }^{88}$

Immigrants other than those likely to impose a fiscal burden might also be deemed to impose external costs on natives. Aliens with criminal records, for example, might be thought likely to impose negative externalities. If these costs are large enough, then the optimal tariff for this class of aliens may be so high as to be prohibitive. We could simply exclude immigrants deemed to be that costly: because a truly prohibitive tariff produces no tariff revenue, it offers no advantage for natives over outright exclusion. Aliens with criminal records might be considered sufficiently costly to justify their exclusion. In fact, current U.S. law makes certain criminal convictions grounds for the exclusion of an alien seeking admission.

${ }^{85}$ Id. sec. 403 (a), 110 Stat. at 2265 (to be codified at 8 U.S.C. $\$ 1613(\mathrm{a})$ ).

${ }^{86}$ See id. sec. $402(a), 110$ Stat. at 2262-64 (to be codified at 8 U.S.C. $\$ 1612(a)$ ). One exception applies to legal permanent residents who have "worked for 40 qualifying quarters." Id. sec. 402(a)(2)(B), 110 Stat. at 2262-63 (to be codified at 8 U.S.C. $\S 1612(\mathrm{a})(2)(\mathrm{B}))$. Thus, under this law, a permanent resident alien must work for a sufficient period of time to earn an entitlement to these benefits.

${ }^{87}$ See id. secs. 402 (b) , 412, 110 Stat at $2264-65,2269-70$ (to be codified at 8 U.S.C. $\S \S 1612(\mathrm{~b}), 1622$ ) (allowing states to restrict alien access to designated federal programs and state public benefits, respectively). Each provision features exceptions that include legal permanent residents who have "worked for 40 qualifying quarters." Id. secs. 402 (b) (2) (B), 412 (b) (2), 110 Stat. at 2264-65, 2269 (to be codified at 8 U.S.C. $\S \S 1612(\mathrm{~b})(2)(\mathrm{B}), 1622(\mathrm{~b})(2))$.

Id. sec. 402 (4), 110 Stat. at 2260 (to be codified at 8 U.S.C. $\$ 1601(4)$ ).

${ }^{89}$ See 8 U.S.C. $\$ 1182(a)(2)$ (1994). Aliens with "a communicable disease of public health significance" or "a physical or mental disorder and behavior associated with the disorder that may pose ... a threat to the property, safety, or welfare of ... others," as well as those who abuse drugs, are also excludable. Id. $\$ 1182(\mathrm{a})(1)(\mathrm{A})$. Aliens believed to be seeking entry to engage in espionage, sabotage, or terrorism are also excludable. See id. §1182(a)(3). 


\section{H. Unemployment}

The foregoing analysis assumes that the supply of labor does not exceed the demand for labor. More precisely, it assumes that the rate of unemployment is no more than the "natural" rate..$^{90}$ If instead the labor market fails to clear, so that unemployment rises above equilibrium levels, then immigration would entail two types of problems. The first arises from the unemployment of immigrants; the second arises from the unemployment of natives.

First, poor immigrants who are (or are likely to become) unemployed may be unlikely to pay enough taxes to cover the costs of public entitlements that they would receive and the congestion costs that they would generate. Thus, even with the "optimal" discrimination against immigrants in taxes and public entitlements, some immigration might have a negative effect on the economic welfare of natives. Unless the tariff is collected up front at the border, some immigrants may avoid paying it.

For this reason, it may be prudent for the United States to generally reserve most employment-based immigration visas for those who have offers of employment in the United States. ${ }^{91}$ In fact, the immigration laws of the United States currently require employer sponsorship for most categories of employment-based immigration visas. ${ }^{92}$ To

${ }^{90}$ Economists define the natural rate of unemployment, also known as the "full employment" or "long-run equilibrium" level of unemployment, as the rate at which the flows of labor in and out of unemployment just balance and "at which the expectations of firms and workers as to the behavior of prices and wages are correct." RUDIGER DORNBUSCH \& STANLEY FISCHER, MACROECONOMICS 549 (4th ed. 1987). For models of equilibrium unemployment, see EFFICIENCY WAGE MODELS OF THE LABOR MARKET (George A. Akerlof \& Janet L. Yellen eds., 1986).

${ }^{11}$ We may also admit immigrants who can otherwise demonstrate that they have sufficient resources to support themselves. Note that although much of the preceding analysis addresses the migration of workers, it also suggests that there is little reason to exclude those who wish to immigrate for any reason, as long as they will make a net positive contribution to the public sector. Employment is only one type of transaction that can yield gains from trade in the private sector. Gains also arise for those who choose to reside in the United States for purely personal reasons, and transact with landlords, merchants, and other natives in the United States, producing gains for all parties to the transactions.

${ }^{92}$ See 8 U.S.C. $\S 1154$ (a)(1)(D) (1994). The only exceptions are aliens with "extraordinary ability in the sciences, arts, education, business, or athletics," id. $\S 1153$ (b)(1)(A), "qualified special immigrants," id. §1153(b)(4), and "qualified immigrants seeking to enter the United States for the purpose of engaging in a new commercial enterprise" that will employ U.S. workers, id. $\$ 1153$ (b)(5)(A). The relatively small number of immigrants falling into these categories, including especially skilled or wealthy aliens, may file petitions on their own behalf. See id. 
enter Canada as an economic immigrant, an applicant must pass a test based on a "point system" that does not strictly require a job offer as a condition of admission, but it awards points for arranged employment and enables those otherwise barred from immigrating to gain admission if they have such an offer. ${ }^{93}$ Furthermore, if immigrants who are unlikely to "pay their way" can be identified, and they do not have sponsors (such as relatives in the country of immigration) willing and able to support them, they can be excluded on that ground. The U.S. immigration statute authorizes the exclusion of aliens deemed "likely at any time to become a public charge."

Second, unemployment among native workers introduces another negative externality from immigration if immigrants increase the involuntary unemployment of natives. Involuntary unemployment entails deadweight loss to the extent that the marginal product of the worker's labor would exceed the value of leisure time to the worker. The U.S. immigration statute responds to this concern by imposing various restrictions, including quantitative restrictions and "labor certification" requirements, on the admission of employmentbased immigrants and temporary workers. ${ }^{95}$ Labor certification is a determination by the Department of Labor that "there are not sufficient workers who are able, willing, qualified ... and available ... at the place where the alien is to perform" the work in question and that the employment of the alien "will not adversely affect the wages and

$\S 1154(\mathrm{a})(1)(\mathrm{C}),(\mathrm{E}),(\mathrm{F})$. Aliens seeking visas as temporary workers under U.S. law also require sponsoring employers. See id. $\$ 1101$ (a) (15)(H).

${ }^{93}$ See BORJAS, FRIENDS OR STRANGERS, supra note 36, at 202-03; Manuel García y Griego, Canada: Flexibility and Control in Immigration and Refugee Policy, in CONTROLLING ImMigration: A Global PERSPECTIVE 119, 126 tbl.4.2 (Wayne A. Cornelius et al. eds., 1994); Daniel Kubat, Canada: Immigration's Humanitarian Challenge, in THE POLITICs OF MIGRATION POLICIES 23, 32 tbl.2 (Daniel Kubat ed., 2d ed. 1993).

${ }^{9} 8$ U.S.C. $\$ 1182$ (a) (4) (1994) ("Any alien who ... at the time of application for a visa ... is likely at any time to become a public charge is excludable."); see infra notes $161,168-71,176$ and accompanying text.

${ }^{95}$ Employment-based immigration is normally capped at 140,000 visas, see 8 U.S.C. $\S 1151$ (d) (1994), but the qualitative restrictions are so stringent and the "labor certification" requirement so burdensome that this ceiling has not in fact been binding. In the 1994 fiscal year, for example, the United States admitted only 90,134 employmentbased immigrants. See JORDAN COMM'N, supra note 15, at 89 chart 25 . Furthermore, no more than 65,000 temporary workers may enter on $\mathrm{H}-1 \mathrm{~B}$ visas "to perform services ... in a specialty occupation... or as a fashion model," 8 U.S.C. $\$ 1101$ (a)(15)(H)(i)(b) (1994), and no more than 66,000 temporary workers may enter on H-2B visas, see id. $\S 1101(\mathrm{a})(15)(\mathrm{H})(\mathrm{ii})(\mathrm{b})$. See $i d . \S 1184(\mathrm{~g})(1)$. Congress imposed these numerical limits on temporary workers only recently, in 1990, and these ceilings represent the first quantitative restrictions ever imposed on any category of nonimmigrants. See STEPHEN H. LEGOMSKY, IMMIGRATION LAW AND POLICY 253 (1992). 
working conditions of workers in the United States similarly employed. ${ }^{965}$ The U.S. immigration statute requires labor certification for most employment-based immigrants, even aliens "who are members of the professions holding advanced degrees," aliens of "exceptional ability," professionals "who hold baccalaureate degrees," and others "performing skilled labor." Through the laborcertification requirement, the U.S. government requires U.S. employers to discriminate against foreign workers: the statute requires an employer to prefer any qualified U.S. worker over any alien, no matter how much better qualified the foreign worker may be.

As long as fiscal policies, employer sponsorship, and the "public charge" provision ensure that these immigrants and temporary workers are expected to have a net positive economic effect on natives, however, it would be in the economic interests of U.S. natives to admit them without protectionist "labor certification" requirements or quantitative restrictions. ${ }^{\text {f9 }}$ A requirement that immigrants have a job offer in hand to obtain a visa makes it unlikely that immigrants could enter a domestic labor market with excess unemployment. Employers would be unlikely to turn to foreign workers if many domestic workers are available. ${ }^{100}$

8 U.S.C. $\$ 1182(\mathrm{a})(5)(\mathrm{A})(\mathrm{i})(1994)$.

${ }^{97}$ Id. $\$ 1153$ (b)(2)-(3); see id. $\$ \S 1154(\mathrm{~b}), 1182(\mathrm{a})(5)(\mathrm{C})$. The requirement also applies to temporary agricultural workers on H-2A visas, see id. $\$ 1188(\mathrm{a})(1)$, and other temporary workers on H-2B visas, see 8 C.F.R. $\$ 214.2(h)(6)$ (iv) (1997). A similar labor "attestation" requirement applies to temporary workers who enter "to perform services as a registered nurse" on H-1A visas, 8 U.S.C. $\$ 1101$ (a) (15) (H) (i) (a) (1994), or "to perform services ... in a specialty occupation ... or as a fashion model" on $\mathrm{H}-1 \mathrm{~B}$ visas, id. $\$ 1101(\mathrm{a})(15)(\mathrm{H})(\mathrm{i})(\mathrm{b})$. The $\mathrm{H}-1 \mathrm{~A}$ visa requires an attestation, for example, that "[t]here would be substantial disruption.... in the delivery of health care services... without the services of such an alien" and "employment of the alien will not adversely affect the wages and working conditions of registered nurses similarly employed." Id. $\S 1182(\mathrm{~m})(2)(\mathrm{A})(\mathrm{i})$-(ii). The H-1B visa requires the employer to attest, for example, that it will offer the alien wages that are at least "the prevailing wage level for the occupational classification in the area of employment" and "working conditions ... that will not adversely affect the working conditions of workers similarly employed." Id. $\$ 1182$ (n)(1)(A) (i) (II), (ii).

${ }^{93}$ See LEGOMSKY, supra note 95, at 199 ("[T] he employer ordinarily must hire a minimally qualified American over a more qualified alien (or hire no one at all)."). The statute requires the U.S. worker to be "equally qualified" only in the case of an alien who "is a member of the teaching profession" or "has exceptional ability in the sciences or the arts." 8 U.S.C. $\$ 1182(\mathrm{a})(5)$ (A) (1994).

${ }^{99}$ See Sykes, supra note 7, at 187 ("The labor certification process ... has little to commend it.... [T] workers to exclude competition.").

${ }^{100}$ See id. ("In the presence of substantial unemployment, the likelihood that an employer would be inclined to hire someone from abroad seems minimal since the 
Furthermore, immigration need not increase the unemployment rate among natives. Immigrants not only expand the local supply of labor but also expand the local demand for labor. Immigrant workers demand goods and services, and many of these goods and services require locally supplied labor. ${ }^{101}$ In fact, studies consistently demonstrate that immigration has little effect on the employment of natives. $^{102}$

Moreover, we would expect labor markets to clear eventually, either because aggregate demand recovers from a negative shock or because excess unemployment drives real wages down until the demand for labor expands to meet supply. If wages cannot adjust, however, then unemployment above the natural rate might persist. Persistent excess unemployment might result, for example, from minimum wage laws that place a floor on nominal wages. ${ }^{103}$ In a labor

employer can draw on a local pool of ... individuals who can be interviewed personally and whose language skills and work history ... are readily verifiable.").

${ }^{101}$ See id. at 169 ("[A]n influx of new immigrants... raises aggregate demand, which ameliorates unemployment problems, other things being equal."); SIMON, supra note 39, at 214 (" $[\mathrm{A}] \mathrm{n}$ immigrant increases the demand for goods and services immediately upon arrival, and hence increases the demand for labor independently of starting work."). This effect stimulates the demand for labor, even setting aside the job-creation effects of immigrants as business owners. For descriptions of the role of immigrant entrepreneurs in the U.S. economy, see BORJAS, FRIENDS OR STRANGERS, supra note 36 , at $163-76$.

${ }^{102}$ Surveys of this empirical literature reveal wide consensus on this conclusion. See, e.g., Borjas, Economics of Immigration, supra note 36, at 1698 ("It is evident that immigration has a weak effect on the employment of natives."); Rachel M. Friedberg \& Jennifer Hunt, The Impact of Immigrants on Host Country Wages, Employment and Growth, J. ECON. PERSP, Spring 1995, at 23, 42 ("There is no evidence of economically significant reductions in native employment."). For example, David Card studied the effect of the arrival of 125,000 Cubans from the port of Mariel who expanded the labor force in Miami by seven percent almost overnight, but found little effect on the unemployment rates among Miami's workers. See David Card, The Impact of the Mariel Boatlift on the Miami Labor Market, 43 INDUS. \& LAB. REL. REV. 245 (1990).

${ }^{103}$ For this reason, economists often criticize minimum wage laws and urge the use of alternatives like the negative income tax as a means of addressing issues of distributive justice. See, e.g., MLLTON FRIEDMAN \& ROSE FRIEDMAN, FREE TO CHOOSE 110-14, 22628 (1979). Despite the broad consensus among economists on this issue, David Card and Alan Krueger note that empirical studies have provided little evidence that minimum wage laws have produced unemployment. See DAVD CARD \& ALAN B. KRUEGER, MYTH AND MEASUREMENT: THE NEW ECONOMICS OF THE MINIMUM WAGE 1-4, 6-7 (1995) (noting the wide agreement among economists that minimum wage laws cause unemployment and summarizing their findings to the contrary). They concede, however: "This is not to say that the employment losses from a much higher minimum wage would be small: the evidence at hand is relevant only for a moderate range of minimum wages, such as those that prevailed in the U.S. labor market during the past few decades." Id. at 393; see id. at 15 ("One explanation for the small effect of the minimum wage in the U.S. labor market is that the minimum wage is set at a low level relative to average wages."); see 
market subject to a minimum wage, once equilibrium wages fall to the minimum wage, the minimum wage is in fact binding, and further immigration of labor runs the risk of generating higher rates of unemployment. ${ }^{104}$ Although this risk appears to be minimal at current levels of immigration, higher levels of unskilled immigration may pose greater risks. ${ }^{105}$

Even in labor markets with excess supply, however, it may be optimal to permit the immigration of more workers. Tariff revenues would benefit the public sector. This benefit must be weighed against the risk of deadweight loss from the involuntary unemployment of natives. That is, it may be optimal to tolerate some unemployment, in order to generate tariff revenues. The optimal level of immigration would equate the external costs associated with the marginal immigrant, including the expected deadweight loss associated with any resulting unemployment of native workers, and the taxes paid by that immigrant.

Thus, even if immigration were to cause some unemployment of natives for any reason, the only implication for the optimal immigration policy would be an adjustment in the optimal tariff. The risk that immigration could cause some unemployment among natives caused by immigration would be merely one more external cost that the Pigouvian component of the optimal tariff would be designed to offset. If the effect of immigration on the unemployment rate among natives is sufficiently small, then the optimal tariff may be lower than a prohibitive tariff, even in labor markets with excess unemployment.

\section{Constitutional Law}

Some commentators have suggested that efforts to impose discriminatory taxes on immigrants could encounter constitutional ob-

also id. at 265 ("We suspect that, at sufficiently high levels, the minimum wage probably does reduce employment."). Thus, even if existing minimum wage laws do not cause unemployment under current conditions, they might do so if equilibrium wages were to fall relative to the minimum wage, as they might under a regime of unrestricted immigration of unskilled workers.

${ }^{104}$ See Barry R. Chiswick, Illegal Immigration and Immigration Control, J. ECON. PERSP., Summer 1988, at 101, 106 (noting that immigration can "lead to a decrease in the employment of native workers, ... if there is downward wage rigidity, say, because the market wage is bounded by the legal minimum wage or a union-imposed wage"); Sykes, supra note 7, at 169 ("An obvious source of this problem is the minimum wage, which may create a pool of unemployed workers that may simply grow with the immigration of less skilled workers.").

${ }^{105}$ See supra notes 102-03. 
jections. ${ }^{106}$ The U.S. Supreme Court, however, has applied a lenient standard of review to federal laws that discriminate against aliens. ${ }^{107}$ In Mathews v. Diaz, ${ }^{108}$ the Court held that Congress could restrict the access of aliens to federal medical insurance. Federal law extends certain Medicare benefits to aliens only if they have been admitted for permanent residence and have also resided in the United States for at least five years. ${ }^{109}$ The Court rejected the argument that this law violates the due process clause of the Fifth Amendment:

The fact that all persons, aliens and citizens alike, are protected by the Due Process Clause does not lead to the further conclusion that all aliens are entitled to enjoy all the advantages of citizenship or, indeed, to the conclusion that all aliens must be placed in a single homogeneous legal classification. For a host of constitutional and statutory provisions rest on the premise that a legitimate distinction between citizens and aliens may justify ... benefits for one class not accorded to the other; and the class of aliens is itself a heterogeneous multitude of persons with a wide-ranging variety of ties to this country.

In particular, the Court pointed to the federal government's plenary power to regulate immigration, which entails sweeping discrimination against aliens:

In the exercise of its broad power over naturalization and immigration, Congress regularly makes rules that would be unacceptable if applied to citizens. The exclusion of aliens and the reservation of the power to deport have no permissible counterpart in the Federal Government's power to regulate the conduct of its own citizenry. The fact that an Act of Congress treats aliens differently from citizens does not in itself imply that such disparate treatment is "invidious."

${ }^{106}$ See, e.g., Bhagwati \& Srinivasan, supra note 27, at 211 ("[T] he (discriminatory) taxation by the country of residence of foreign labour is fraught with numerous difficulties from legal, constitutional, human-rights and political standpoints."); Chiswick, supra note 27, at $309 \mathrm{n} .34$ (predicting that an "annual income tax surcharge" would raise the objection that it is unconstitutional).

107 "[A]lienage classifications created by federal law will be subjected to only the rational basis standard of review." JOHN E. NOWAK \& RONALD D. ROTUNDA, CONSTITUTIONAL LAW $\S 14.12$, at 704 (4th ed. 1991). "[I]t would appear that the federal government may use a citizenship classification so long as it is arguably related to a federal interest." Id.

${ }^{103} 426$ U.S. 67 (1976).

${ }^{109}$ See 42 U.S.C. $\$ 13950$ (2) (B) (1994).

${ }^{110}$ Diaz, 426 U.S. at 78.

${ }^{111}$ Id. at 79-80 (footnotes omitted). The Court's deferential review of federal laws that discriminate against aliens contrasts sharply with the heightened scrutiny that the Court applies to state laws that discriminate against aliens: 
This deferential standard of review for federal laws discriminating against aliens (and also discriminating between immigrant and nonimmigrant aliens) in the distribution of welfare benefits suggests that the Court would uphold similar discrimination in our tax laws, for example, with respect to the earned income tax credit. ${ }^{112}$

Although a full normative analysis of the deference shown by the Court in Mathews v. Diaz is beyond the scope of this paper, it is worth noting some of the issues raised. Gerald Rosberg, for example, has criticized Mathews v. Diaz. He asks whether the plenary power to restrict immigration necessarily implies such broad powers in the context of the Medicare statute, which "was not on its face concerned with immigration and ... reflected no judgment ... about the classes of aliens that should be admitted to the United States."113 Similarly, Alexander Aleinikoff has argued:

[T] he courts have wrongly assumed that every federal regulation based on alienage is necessarily sustainable as an exercise of the immigration power. It should be apparent that some statutes burdening aliens are based on considerations other than a policy judgment regarding the

[W] hen state ... laws classify persons on the basis of United States citizenship for the purpose of distributing economic benefits ..., the law will be subjected to strict judicial scrutiny. In this situation, the Court recognizes that classifications based on alienage should be deemed "suspect" and upheld only if necessary to promote a compelling or overriding interest.

NOWAK \& ROTUNDA, supra note 107, at 703 (footnote omitted); see Graham v. Richardson, 403 U.S. 365, 376 (1971) (holding that the equal protection clause of the Fourteenth Amendment prevents a state from conditioning welfare benefits on either U.S. citizenship or residence in the United States for a specified number of years). The Court in Mathews v. Diaz distinguished Graham v. Richardson by pointing to the exclusive federal power over the "entry and residence of aliens." Diaz, 426 U.S. at 84. The Court stressed that "the Fourteenth Amendment's limits on state powers are substantially different from the constitutional provisions applicable to the federal power over immigration and naturalization." Id. at 86-87.

112 Indeed, in defending the discrimination at issue in Mathews $v$. Diaz, the Court drew an analogy between medical benefits and tax benefits: "The task of classifying persons for medical benefits, like the task of drawing lines for federal tax purposes, inevitably requires that some persons who have an almost equally strong claim to favored treatment be placed on different sides of the line ...." Diaz, 426 U.S. at 83.

${ }^{113}$ Gerald M. Rosberg, The Protection of Aliens from Discriminatory Treatment by the $\mathrm{Na}$ tional Government, 1977 SUP. GT. REV. 275, 337; see id. at 317, 334 ("The provision restricting alien participation in the Medicare insurance program was not in any obvious way concerned with immigration."); see also id. at 335 ("[T] he great majority of the statutory provisions discriminating against resident aliens, certainly including the provision at issue in Diaz, have no explicit connection with immigration. They are not codified in the immigration laws."). 
number and classes of aliens who may enter or remain in the United States.

Rosberg describes the objective of such statutes at the most general level: "Most federal classifications based on alienage... are ultimately designed to enhance the economic well-being of members of the national polity at the expense of outsiders." 115

As Rosberg notes, "[i] t is tempting to say that the goal of enhancing the economic well-being of citizens at the expense of aliens makes discrimination 'an end in itself' and is inherently illegitimate."116 This claim, however, would also imply that immigration restrictions are also suspect, because immigration restrictions by their very nature discriminate against aliens, supposedly in order to promote the economic welfare of citizens. Indeed, Michael Perry argues that the federal power to discriminate against aliens follows logically from the federal power to restrict immigration:

Few would take issue with the proposition that the members of a political community may appropriately decide whether, to what extent, and under what conditions persons who are not members may enter the territory of the political community and share its resources and largesse. This ... necessarily entails the view that a person, in some respects at least, is more deserving by virtue of his status as a citizen than a person who is not a citizen. And this view is inconsistent with the notion that alienage is a morally irrelevant status ....

To deny that the federal government has the power to discriminate against aliens is to cast doubt on the federal power to exclude them. If we accept the federal power to exclude aliens from the United States entirely, then this power would seem to include less restrictive forms of discrimination against aliens.

Rosberg asks: "If aliens have no right to enter the United States and the federal government can exclude them on any remotely reasonable basis, can it not condition their admission on acceptance of any terms it dictates?"118 For example, most nonimmigrants, including tourists, are admitted without the right to work in the United

114 T. Alexander Aleinikoff, Federal Regulation of Aliens and the Constitution, 83 AM. J. INT'L L. 862, 869-70 (1989) (footnote omitted).

$" 15$ Rosberg, supra note 113, at 314-15.

${ }^{116}$ Id. at 307 (quoting Truax v. Raich, 239 U.S. 33, 41 (1915)) (footnotes omitted).

${ }^{17}$ Michael J. Perry, Modern Equal Protection: A Conceptualization and Appraisal, 79 COLUM. L. REV. 1023, 1061 (1979).

${ }^{118}$ Rosberg, supra note 113, at 328. 
States; they must accept this condition in order to enter. ${ }^{119}$ Rosberg concedes that this condition "is plainly an integral part of the immigration scheme... debated in terms of its impact on immigration policy," ${ }^{\text {,120 }}$ which raises the question: "Is it not possible to say... that aliens admitted for permanent residence are admitted subject to certain conditions?"121 Nevertheless, Rosberg criticizes the Court's treatment of the statutory provisions at issue in Mathews v. Diaz, which "are not part of any bargain between the government and the aliens who enter," because they "are simply not a part of the congressional judgment about the classes of aliens that should be admitted to the United States."

Even if Congress did not view the provision in Mathews v. Diaz as part of its immigration policy, however, current debates over immigration make it abundantly clear that immigrant access to public entitlements is now understood to be part of immigration policy. ${ }^{123}$ While enacting sweeping new restrictions on this access in 1996, Congress adopted a statement of the "immigration policy of the United States" that includes the principles that "the availability of public benefits not constitute an incentive for immigration to the United States" and that "aliens within the Nation's borders not depend on public resources to meet their needs."

"19 See id. at 329 ("If the term was unacceptable to the nonimmigrant, he should not have come.").

${ }^{120} I d$. at 335 .

${ }^{121}$ Id. at 329. As Rosberg notes, however, the conditions on entry must be reasonable. "Otherwise, the government could impose the most appalling restrictions on aliens by inducing them to 'accept' these restrictions as the price of admission to the United States." Id. Rosberg asks for "evidence that the political process has acted fairly in balancing their interests against the interests of the United States." Id. at 335.

${ }_{122} I d$. at 335-36.

${ }^{123}$ See Linda S. Bosniak, Membership, Equality, and the Difference that Alienage Makes, 69 N.Y.U. L. REV. 1047, 1048-54 (1994) (reviewing current efforts to exclude aliens from various benefits as expressions of anxiety over immigration).

${ }^{124}$ Personal Responsibility and Work Opportunity Reconciliation Act of 1996, Pub. L. No. 104-193, sec. 400 (2), 110 Stat. 2105, 2260 (to be codified at 8 U.S.C. $§ 1601$ (2)). The two principles set forth by Congress correspond to two senses in which restrictions on public benefits are "characterized by supporters as integral to their broader immigration restriction program." Bosniak, supra note 123, at 1053 . The first principle illustrates the view that "such measures are ... an indirect means of deterring the entry ... of immigrants." Id.; see F.H. Buckley, The Political Economy of Immigration Policies, 16 INT'L REV. L. \& ECON. 81, 81 (1996) ("Current proposals to cut welfare benefits to recent immigrants might usefully deter unwanted immigrants ...."); Hiroshi Motomura, Immigration and Alienage, Federalism and Proposition 187, 35 VA. J. INT'L L. 201, 202 (1994) ("Often, the intended and/or actual effect of an alienage rule is to affect immigration patterns."). In this sense, these measures are instruments of immigration policy as surely 
government interest ... to assure that aliens be self-reliant in accordance with national immigration policy."

From the perspective of the economic welfare of natives, immigrant access to public entitlements is intimately related to immigration policy, because the fiscal policies applied to any set of immigrants will determine the economic costs and benefits of allowing their immigration. Congress may be inclined to exclude unskilled immigrants in the absence of restrictions on immigrant access to public benefits. ${ }^{126}$ In this sense, Congress may deem such restrictions to be important and necessary conditions attached to the right to immigrate. ${ }^{127}$ These considerations suggest that the Court will continue to subject such restrictions to the same type of deferential review conducted in Mathews $v$. Diaz. ${ }^{128}$

\section{J. Citizenship, Guestworkers, and Illegal Immigration}

Up to this point, I have analyzed immigration independent of the issue of naturalization as a U.S. citizen. The possibility of naturalization raises the question of whether discrimination against the immigrant would cease once the immigrant obtains citizenship. If so, then immigrants might anticipate citizenship and subsequent access to

as tariffs are instruments of trade policy. The second principle expresses the view that "the exclusion of aliens from access to various ... benefits ... properly preserves the benefits of membership for those deemed to belong within ... the national community." Bosniak, supra note 123 , at 1053.

${ }^{125}$ Personal Responsibility and Work Opportunity Reconciliation Act, sec. 400(5), 110 Stat. at 2260 (to be codified at 8 U.S.C. $\$ 1601(5)$ ).

${ }^{126}$ See Legomsky, supra note 79, at 1466 ("Liberal benefit rules might induce Congress to think twice before admitting a particular class of immigrants in the first place.").

127 See Johnson, supra note 78, at 1538 ("Some would argue that, in allocating the scarce privilege of immigrating, it is entirely permissible, indeed advisable, to condition entry on the potential immigrants' economic self-sufficiency and limit their access to public benefits once they immigrate."). The nature of a discriminatory tax as a condition on immigration becomes transparent once it is characterized as a form of entry fee. For example, Barry Chiswick has proposed that the United States impose an "annual income tax surcharge" on immigrants as "a voluntary substitute" for a "large entry fee" that the immigrant could also choose to pay immediately upon admission. Chiswick, supra note 27, at 309 \& n.34.

${ }^{128}$ This level of scrutiny need not be as deferential as that applied to other aspects of immigration policy. See Motomura, supra note 124, at 210 (suggesting that the Diaz Court did not exhibit the "total judicial deference" seen in other immigration cases). Nevertheless, discrimination between citizens and aliens in fiscal policies seems likely to pass muster. See id. at 211 ("If one views alienage as something less than full membership, the restriction on Medicare benefits in Diaz was just the sort of difference between citizens and aliens that might seem reasonable."). 
public entitlements. If the period of alienage is too short to permit the collection of an appropriate tariff, then fiscal policies limited to aliens may fail to deter all immigration with negative economic impact on natives.

Citizenship, however, need not imply access to public entitlements. Discrimination against immigrants in taxes and public entitlements might continue for some time even after an immigrant naturalizes. ${ }^{129}$ One could adjust the duration as well as the extent or severity of discrimination against immigrants in designing the "optimal tariff." If immigrants become a significant portion of the electorate, however, then there may be limits to how long fiscal policies could discriminate against immigrants. ${ }^{130}$ Furthermore, such discrimination against immigrant citizens would pose serious constitutional problems. ${ }^{131}$

Alternatively, we can separate admission to the United States from access to naturalization. Indeed, under U.S. law, only aliens "admitted for permanent residence" may naturalize as U.S. citizens. ${ }^{132}$ Aliens admitted on nonimmigrant visas only, including temporary workers, are not admitted as permanent residents and are thus not eligible to naturalize and also not eligible for most public entitlements. ${ }^{139}$ In fact, the United States has in the past regularly admitted more temporary workers annually than the number of permanent residents admitted on employment-based visas. ${ }^{134}$ Countries in West-

${ }^{100}$ A Republican-sponsored bill, H.R. 4, 104th Cong. (1995), would have excluded some immigrants from benefits even after they had naturalized as U.S. citizens. See Senate OKs Welfare Bill with Sweeping Immigration Consequences, 72 INTERPRETER RELEASES 1365 (1995). President Clinton, however, vetoed that welfare bill. See Immigration, Other Priorities on Congressional Agenda for 1996, 73 INIERPRETER RELEASES 133, 135 (1996).

${ }^{100}$ See Sykes, supra note 7, at 179 (“[D]isadvantaged aliens who become citizens might well develop the political power to force an increase in payments under such programs.").

${ }^{131}$ In Schneider v. Rusk, 377 U.S. 163 (1964), the U.S. Supreme Court struck down a federal law providing that a naturalized U.S. citizen could lose U.S. citizenship by residing abroad. This law discriminated against naturalized citizens because no such rule applied to native-born citizens residing abroad. The Court held that such discrimination violated the Fifth Amendment by creating "a second-class citizenship." Id. at 169; see id. at 165 ("We start from the premise that the rights of citizenship of the native born and of the naturalized person are of the same dignity and are coextensive."); see also Motomura, supra note 124, at 213-14 ("Constitutional difficulties arise when disabilities visited on aliens carry over as disabilities that handicap their lives as citizens....").

${ }^{1 \$ 2} 8$ U.S.C. $\$ 1427$ (a) (1994).

193 See supra note 82.

${ }^{134}$ See Sykes, supra note 7, at 188. 
ern Europe have made heavy use of similar "guestworker" programs.

Classes of foreign workers deemed likely to have a negative economic impact if treated as citizens can be admitted on nonimmigrant visas without the same entitlement to citizenship implied by immigrant visas. The host country can keep an alien worker in guestworker status for as long as it deems necessary to collect the appropriate tariff. The collection of this tariff need not entail permanent status as an alien: the host country could allow the alien to naturalize after a sufficient probationary period has passed. ${ }^{196}$ The appropriate tariff would at least cover the present discounted value of any net costs that we expect the worker to impose on natives after the worker obtains U.S. citizenship.

Guestworker status may strike some observers as an unjust form of second-class membership. ${ }^{137}$ Michael Walzer argues:

Political justice is a bar to permanent alienage-either for particular individuals or for a class of changing individuals. At least, this is true in a democracy.... No democratic state can tolerate the establishment of a fixed status between citizen and foreigner.... Men and women are either subject to the state's authority, or they are not; and if they are subject, they must be given a say, and ultimately an equal say, in what that authority does. Democratic citizens, then, have a choice: if they want to bring in new workers, they must be prepared to enlarge their own membership; if they are unwilling to accept new members, they must find ways within the limits of the domestic labor market to get socially necessary work done. And those are their only choices.

If Walzer's all-or-nothing choice precludes the use of guestworkers, however, then his approach is likely to condemn unskilled alien workers to an even worse fate. If the welfare of natives is the decisive consideration in formulation of immigration policy as a matter of po-

135 See, e.g., Philip L. Martin, Germany: Reluctant Land of Immigration, in CONTROLIING IMMIGRATION: A GLOBAL PERSPECTIVE, supra note 93, at 189, 198-210, 217-20 (describing the history of migrant worker programs in Germany).

${ }^{136}$ Nor would a guestworker program produce a hereditary class of alien residents in the United States, because the Fourteenth Amendment of the U.S. Constitution gives U.S. citizenship to anyone born in the United States, including the children of nonimmigrants. See supra note 63. Thus, guestworker programs in the United States cannot create the type of caste society that they might in countries that do not provide birthright citizenship.

${ }_{137}$ See WAIZER, supra note 60 , at 56-61.

193 Id. at 61 . 
litical reality, then the alternative to guestworker status for most unskilled aliens would be exclusion from the United States. ${ }^{139}$

Although a full discussion of "political justice" is outside the scope of this discussion, which takes the welfare of natives to be our sole objective, it is important to compare guestworker programs with exclusion (which would be the most likely alternative policy) in light of these concerns. Exclusion offers no obvious advantage over a guestworker program, whether from the standpoint of political justice or from the perspective of migrant welfare. Like admission under a guestworker program, exclusion is an exercise of "the state's authority" over aliens, and neither policy offers aliens any say in the formulation of that policy. ${ }^{140}$ Exclusion discriminates against aliens just as surely as guestworker status does. If we must choose between these two forms of discrimination, then we should opt for guestworker status, because complete exclusion from the United States is the more severe form of discrimination and inflicts the greater harm on the alien. The guestworker program at least offers the migrant a choice, and by choosing to come, the migrant reveals a preference for guestworker status in the United States over the alternative of exclusion. ${ }^{141}$ If guestworker status makes us uneasy, then exclusion should only make us more so, because it keeps alien workers in a state of poverty that they would prefer to escape as guestworkers. ${ }^{142}$ From a welfare

139 See SIMON, supra note 39, at 303 ("Being a temporary worker may well be inferior, and may even seem 'unfair,' compared to full admission as a legal immigrant, but this simply is not a realistic alternative; to compare a temporary worker program unfavorably against a non-existent alternative is either thoughtless or dishonest.").

${ }^{140}$ Carens concedes that to admit guestworkers without "giving them the opportunity to become citizens" is "incompatible with our liberal democratic principles," but adds that "so is a restrictive policy on immigration." Carens, supra note 26, at 268.

${ }^{141}$ See SIMON, supra note 39, at 310 (arguing that if we wish to show respect for the alien's "human dignity," then "giving people the choice of whether they do or do not wish to serve as guestworkers seems to be more dignified than deciding for them that serving as guestworkers would not be good for them"); see also id. at 303 ("Participating in the program must be better for at least some persons than not participating, or else there would be no participants in the program."). There seems to be little reason to secondguess the alien regarding the decision to seek employment as a guestworker. While paternalistic regulations might be appropriate when we have evidence that individuals will make irrational choices and we believe the government can make superior choices, it would be difficult to declare the decision to become a guestworker irrational or harmful, given the alternatives that these aliens face.

${ }^{142}$ If we think that a guestworker program mistreats the alien, then Julian Simon responds: "Here we must ask the fundamental practical and moral question: Compared to what?" Id. at 303 . He explains: “Compared to a beautiful world of no borders and perfect freedom to live with full rights wherever one likes, having both citizens and non-citizens within a country may seem undesirable. But compared to a 
perspective, it would be foolish public policy to exclude the worker from our labor market as well as from U.S. citizenship, given that admission as a guestworker would make both the alien worker and U.S. natives better off.

Furthermore, the alternative in reality, for many migrant workers, is probably entry as an illegal immigrant. A liberalized guestworker program would relieve the pressures in the labor market that generate illegal immigration. In fact, the United States brought in hundreds of thousands of agricultural guestworkers from Mexico annually for most years of the "bracero" program from 1942 to 1964, and the decline in admissions of such workers was closely correlated with the rise in the estimated number of undocumented aliens. ${ }^{143}$

Legalization of this migration would serve the interests of all parties concerned. The workers would gain from having a legal alternative to illegal entry and life as an undocumented alien, which leaves them vulnerable to deportation by the government and to abuse by employers. ${ }^{144}$ Illegal immigration implies that the undocumented alien must bear the costs of evading detection, apprehension, and deportation by the government. As a result, producers of counterfeit documents, smugglers, and unscrupulous employers can extract significant quota rents from the immigrant.

At the same time, the government must waste scarce lawenforcement resources on the detection, apprehension, and deportation of large numbers of undocumented aliens. ${ }^{145}$ A liberalized guestworker program would also avoid the inefficiencies that private

world in which every country controls who may enter... the comparison may seem quite different." Id. at 310.

${ }^{143}$ Simon concludes: "Experience with the bracero program provides solid evidence that a legal temporary worker program will indeed reduce illegal immigration .... Id. at 302 (footnote omitted); see id. at 286 fig.15.1; Hearing on Proposal to Amend the Immigration and Nationality Act, House Comm. on Education and Labor, Subcomm. on Labor Standards, 98th Cong., 27-28 tbl.1 (1983) (statement of George F. Sorn); Sykes, supra note 7, at 189. As Calavita observes, "when the government got out of the business of importing braceros, ... illegal immigrants replaced the braceros of the past." Calavita, supra note 15, at 146 (noting that the termination of the bracero program "turned legal braceros into today's undocumented farm workers").

144 See SiMON, supra note 39, at 303 (arguing that being a guestworker "must be better than being an illegal; if this is not obvious, then the fact that many Mexicans chose the bracero program rather than entering illegally should be evidence enough"); Johnson, supra note 78, at 1544 (noting that given the "threat of deportation" it is not surprising that "undocumented immigrants historically have been, and continue to be, exploited in the labor market" (footnote omitted)).

${ }^{145}$ See Sykes, supra note 7, at 191 ("These expenditures could be reduced if workers desiring employment in the United States could enter readily as temporary workers."). 
employers encounter when hiring employees on the black market. ${ }^{146}$ Furthermore, insofar as a liberalized guestworker program serves as a substitute for illegal immigration, such a program may increase tax revenues by improving compliance with tax laws: employers hiring migrant workers on the black market may also be more prone to evade taxes than those hiring legal guestworkers. ${ }^{147}$ Through a positive tariff, the government can collect some share of the value that immigrants would enjoy as a result of legal status, including quota rents they would otherwise transfer to forgers, smugglers, and unscrupulous employers. Natives would derive more benefit with these rents going to the public treasury instead, which would allow a reduction in other taxes.

More skilled immigrants, however, will make positive contributions to the public sector even when treated as citizens. There would be little reason from an economic perspective to deny these immigrants access to citizenship or to delay their naturalization for a significant period of time. On the contrary, because their presence yields external benefits, it is in the interest of the country of immigration to promote their immigration and to strengthen their ties to the host country. Legal status that includes the option of U.S. citizenship in relatively short order would make our offer more attractive to prospective skilled immigrants and increase the likelihood that they will stay once they take up residence here. Thus, at least in the case of skilled immigrants, we can make the offer of citizenship that Walzer demands and simultaneously further the economic interest of natives.

In fact, the categories of employment-based immigration visas under U.S. law are largely designed to select particularly skilled or wealthy immigrants for permanent residence. Quotas for employment-based immigration allocate most visas to "priority workers," which include aliens with "extraordinary ability," "outstanding professors and researchers," and "multinational executives and managers," to "members of the professions holding advanced degrees or aliens of exceptional ability," and to other "skilled workers" and

146 See id. ("An expansion of the temporary worker program would most likely facilitate better matching of employer needs with employee skills.... By contrast, when employers hire illegals, they must search in a potentially thin and possibly clandestine local market in which worker's [sic] backgrounds, experience, and work histories are generally unverifiable.").

${ }^{147}$ See id. at 192 ("Presently, in cases where employers are willing to hire undocumented workers despite the threat of sanctions, they may also be willing to risk the consequences of omitting them from the payroll for purposes of the payroll tax and tax withholding."). 
"professionals." The vast majority of employment-based immigrants enter through these categories. ${ }^{149}$ Few unskilled workers can obtain such visas: of the 140,000 visas allocated to employment-based immigration per year, only 10,000 may go to unskilled workers. ${ }^{150}$

More employment-based visas are available for unskilled workers who enter as nonimmigrants. Unskilled workers may enter on $\mathrm{H}-2 \mathrm{~A}$ visas as agricultural workers, which are not subject to a quantitative restriction, or on $\mathrm{H}-2 \mathrm{~B}$ visas for workers who come "temporarily to the United States to perform ... temporary service or labor," which are limited to 66,000 per year. ${ }^{151}$ This "double requirement of 'temporariness" requires the H-2B alien not only to enter temporarily but also to fill a temporary job. ${ }^{152}$ Furthermore, both visas are subject to labor certification requirements. ${ }^{153}$ As a result of these requirements, the demand for each of these visas has remained low, but the liberalization or elimination of these requirements could greatly increase use of these programs. ${ }^{154}$

${ }^{148} 8$ U.S.C. $\$ 1153$ (b) (1)-(3) (1994).

149 See JORDAN COMM'N, supra note 15, at 89 chart 25 . Smaller numbers of visas are available for unskilled workers, see 8 U.S.C. $\$ 1153(\mathrm{~b})(3)$ (A)(iii), (B) (1994), for "qualified special immigrants," $i d$. $\$ 1153(\mathrm{~b})(4)$, and for foreign investors, who must invest at least $\$ 1$ million in a new commercial enterprise that will create at least ten jobs in the United States, see id. §1153(b) (5).
${ }^{130}$ See 8 U.S.C. $\$ \S 1151$ (d) (1) (A), 1153(b) (3) (A) (iii), (B) (1994).
${ }^{151} I d . \S 1101(\mathrm{a})(15)(\mathrm{H})(\mathrm{ii}) ;$ see id. $\S 1184(\mathrm{~g})(\mathrm{1})(\mathrm{B})$.
${ }^{152}$ ALEINIKOFF ET AL., supra note 65 , at 244.
${ }^{153}$ See 8 U.S.C. $\$ 1188$ (a) (1) (1994); 8 C.F.R. $\$ 214.2$ (h) (6) (iv) (1994).

${ }^{154}$ Admissions under $\mathrm{H}-2 \mathrm{~B}$ visas has remained below one third of the quota limit in recent years, and admissions under $\mathrm{H}-2 \mathrm{~A}$ visas have been similar. ALEINIKOFF ET AL, supra note 65, at 244-45. "It is clear, however, that the demand would be much higher but for the double 'temporariness' requirement." Id. at 245 ("These rules have made it very difficult to use the H-2B category for certain types of workers-nannies for example."); see Sykes, supra note 7, at 189 (reporting that "[a]dmissions under the H-2 categories have been modest in recent years, on the order of 35,000 for the two combined" and explaining that "because of the transaction costs of obtaining a visa coupled with the limited certifications for labor shortages in the agricultural sector, employers often find that these visas are not worth the effort to procure"). Sykes argues:

Because all of these worker categories require employer sponsorship, it is ... difficult to fashion compelling justification for explicit or implicit ceilings (in the form of labor certification and high approval costs) on the number of admissions. Temporary workers are even less likely than permanent immigrants to be a net drain on the public sector, given that these workers pay taxes just like anyone else, federal funds cannot be used to provide them with public safety net benefits, and their right to remain in the country generally depends on continuing employment.

$I d$. (footnote omitted). 
Employment-based immigration of unskilled workers into the United States has largely taken the form of illegal rather than legal immigration, with this undocumented population growing by as many as 300,000 aliens each year. ${ }^{155}$ Given that undocumented immigrants have little access to public entitlements, they may make a positive contribution to public coffers even under current fiscal policies. ${ }^{156}$ These considerations suggest that the Pigouvian tariff, which would be sufficient to internalize the external costs of their immigration, may be well below the prohibitive level. Under a liberalized guestworker policy without quotas, more unskilled workers would probably enter legally than the few who do so under our current laws, even if we were to impose the optimal tariff on these guestworkers and continue to exclude them from most public benefits. ${ }^{157}$

Under current employment-based immigration policies, the United States reserves permanent residence, and thus citizenship, for the skilled and the wealthy. Similarly, the "points system" used in Canada to evaluate economic immigrants awards points for education, vocational skills, and experience, among other criteria, and thereby screens visa applicants for skills and wealth. ${ }^{158}$ As in the

135 See FIX \& PASSEL, supra note 24, at 24.

${ }^{156}$ See SIMON, supra note 39, at 296 (“On balance... natives exploit illegal immigrants through the public coffers by taking much more from the illegals in taxes than is spent on them in public expenditures."); Sykes, supra note 7, at 191 ("[T] here is no clear evidence that undocumented aliens as a group are a net drain on the public treasury once their contributions to tax revenues are taken into account.").

${ }^{157}$ The maximization of tariff revenues would militate in favor of keeping the tariff well below the prohibitive level, especially if the elasticity of the supply of unskilled immigrant labor implies that "market power" considerations are weak. The degree of international inequality in wages and the magnitude of illegal immigration into the United States suggest that a large number of aliens may be willing to enter as guestworkers even if this required paying a significant tariff. Furthermore, the fact that we cannot enforce our immigration restrictions perfectly and costlessly would militate in favor of less discrimination against guestworkers in our tax laws, because discrimination may induce aliens to immigrate illegally rather than as guestworkers if they can thereby avoid a positive tariff. Given the phenomenon of illegal immigration, the optimal tariff may even be below the Pigouvian level. With taxes below the Pigouvian level, guestworkers would impose a net external cost on natives, but if illegal immigrants have greater net external costs than guestworkers, then tariff reductions may bring net fiscal benefits by reducing illegal immigration.

${ }_{153}$ See BORJAS, FRIENDS OR STRANGERS, supra note 36, at 202; Buckley, supra note 124, at 9495; García y Griego, supra note 93, at 126 tbl.4.2; Kubat, supra note 93, at 32 tbl.2. Canada offers lower pass marks for business immigrants, including entrepreneurs and aliens with capital to invest. See Buckley, supra note 124, at 95; Kubat, supra note 93, at 31 . 
United States, those admitted as immigrants to Canada are eligible to apply for citizenship after a waiting period. ${ }^{159}$

Given that the optimal tariff may well call for discrimination in favor of skilled immigrants and against similarly skilled natives, we might view an offer of citizenship after a short waiting period as an efficient supplement or alternative to a negative tariff. ${ }^{.60}$ That is, the option value of citizenship for the skilled immigrant, whether psychic or economic, would probably equal or exceed any economic cost to natives from making this offer. Therefore, an offer of U.S. citizenship for skilled immigrants after a short waiting period would be an efficient means for improving our offer of employment in the United States.

\section{K. Family-Based Immigration as a Negative Tariff}

Similarly, immigration laws that allow skilled immigrants to petition for the immigration of their relatives might be viewed as an efficient substitute for an explicit negative tariff. That is, the right to sponsor relatives for immigration visas on more favorable terms than they could otherwise obtain may well stimulate skilled immigration at lower cost to natives than a formal negative tariff designed to be equally attractive. For example, for family-based immigrants, a country of immigration might dispense with the requirement of employer sponsorship applied to employment-based immigrants. In fact, U.S. immigration laws require employer sponsorship only for employmentbased visas: family-based immigration does not require a petition from a prospective employer. ${ }^{161}$ The prospect of family reunification may attract skilled aliens to the United States who would not otherwise immigrate.

159 The waiting period is only three years in Canada, see Kubat, supra note 93, at 39, whereas it is generally five years in the United States, see 8 U.S.C. $\$ 1427$ (a) (1994). An immigrant who is married to a U.S. citizen may naturalize after only three years in the United States if they have been "living in marital union" during this period. Id. $\S 1430$ (a).

${ }^{160}$ The optimal policy may entail discrimination against even some skilled immigrants who make a positive contribution to the public sector. An offer of citizenship, however, would not make it impossible to discriminate against immigrants: it would only limit the period during which we could discriminate; it would not eliminate this period. If this period is too short to allow us to impose the optimal tariff, then we lose some tax revenues that we could otherwise have extracted from the immigrant.

${ }^{161}$ Evidence of "an offer of prearranged employment," however, may be useful in avoiding exclusion as an alien likely to become a public charge. See 22 C.F.R. $\S 40.41$ (c) (1996). 
As an additional benefit for the immigrant family, we might also offer these family-based immigrants permanent residence and access to citizenship, which would imply nondiscriminatory taxes and access to public entitlements, even if we might otherwise admit aliens with similar skills only on nonimmigrant visas and impose a positive tariff on them. Before Congress enacted new restrictions on immigrant access to public entitlements in 1996, the United States generally provided such access to family-based immigrants even before naturalization: as legal permanent resident aliens, they enjoyed formal access to most of the public entitlements provided to citizens. ${ }^{162}$ While the new restrictions drastically curtail immigrant access to public benefits, U.S. law continues to provide permanent resident aliens greater access to public benefits than that enjoyed by nonimmigrant aliens. ${ }^{163}$ Furthermore, as permanent residents, family-based immigrants are eligible for naturalization as U.S. citizens, and once naturalized, enjoy the same fiscal policies applied to U.S. natives. This equal treatment, even for less skilled immigrants, may be in the economic interest of natives insofar as skilled aliens contemplating immigration to the United States take into account the benefits their relatives will enjoy as family-based immigrants. ${ }^{164}$

In this sense, family-based immigration may act as an implicit negative tariff. Like an explicit negative tariff, family-based immigration may reduce the external benefits associated with each individual skilled immigrant, but as long as the family as a whole does not impose a net cost, family-based immigration may stimulate enough

162 Even before 1996, however, permanent resident aliens had to reside in the United States for at least five years to become eligible for certain Medicare benefits. See 42 U.S.C. $\$ 1395 \circ(2)$ (B) (1994). Other statutory provisions in effect imposed important restrictions on immigrant access to public entitlements for some years after entry while maintaining such access in theory. See infra notes $168,176$.

${ }^{169}$ For a summary of the new restrictions on immigrant access to public benefits, see supra Part I.G.

${ }^{16}$ See BORJAS, FRIENDS OR STRANGERS, supra note 36 , at 188 ("In fact, it is families who enter the immigration market, compare the various offers, and choose the option that maximizes the household's economic well-being. Put simply, the family as a whole and individual members within the household take actions that maximize total family income ...." (footnote omitted)). Borjas suggests: "Policies that favor the immigration of families ... may actually increase the average skills of immigrants." Id. at 191. Borjas finds some empirical evidence suggesting that family considerations induce more skilled workers to immigrate. He compares the incomes of single immigrant men with those of married immigrant men; he also compares the incomes of men who immigrated alone with those of men who immigrated contemporaneously with relatives. See id. In both cases, immigrants with more family ties had higher incomes. See id. He infers that "family ties increase the average skill level of the immigrant flow." Id. 
skilled immigration to be in the economic interest of natives. Furthermore, the presence of a sponsoring relative in the United States improves the likelihood that the sponsored relatives will integrate smoothly into the U.S. economy and will thus yield external benefits for natives rather than costs. ${ }^{165}$ Thus, an offer of family-based immigration may be an efficient means to improve our employment offer to skilled immigrants while maintaining a nondiscriminatory tax system. That is, once we account for the congestion costs imposed by relatives and possible net transfers, the optimal tariff for the skilled immigrant may go from negative to zero.

We have already seen that it may be efficient to allow even the least skilled immigrant to bring a spouse and dependent children. The efficient policy may vary with the wealth of the immigrant, insofar as a wealthier immigrant may be willing to pay more for the immigration of a given relative. In the case of a wealthy immigrant, the economic value of a relative's immigration may be more likely to exceed the external costs that the relative would impose on natives. Given that skilled immigrants have higher levels of wealth than unskilled immigrants, their willingness to pay for the immigration of relatives may make it efficient to admit more distant relatives of skilled immigrants than of unskilled immigrants. If so, it may be optimal to allow skilled immigrants to sponsor a wider set of relatives than unskilled immigrants. Natives can capture some of the resulting surplus by raising the tariff on the skilled immigrant by enough to cover any net external costs associated with these sponsored immigrants.

Finally, even if family-based immigration were not an economically efficient incentive for skilled immigrants, it may still be in the economic interest of natives if political constraints prevent the implementation of an explicit negative tariff. It may be worthwhile to resort to inefficient policy instruments if the first-best instrument is politically infeasible. If these inefficient instruments stimulate skilled immigration, then their benefits may still exceed their costs.

From this perspective, current U.S. laws regarding family-based immigration appear to be generally consistent with the economic in-

${ }^{165}$ See Hearings Before the Subcomm. on Immigration, Refugees, and Intermational Law of the Comm. on the Judiciary, House of Representatives, on H.R. 5115 and S. 2104: Reform of Legal Immigration, 100th Cong. 426 (1988) (statement of Doris Meissner) ("Families are the facilitators of an immigrant's social, economic and ... political integration and enhance the immigrant's ability to make a successful transition to the new community and society."). 
terest of natives. Under current U.S. law, immigrants may petition for the immigration not only of their spouses and children but ultimately also of their parents, adult sons and daughters, and siblings. ${ }^{166}$ The United States does not grant temporary workers "permanent resident" status, however, and so they may not petition for the admission of the same classes of relatives (either as immigrants or nonimmigrants), but they may bring spouses and minor children with them into the United States as nonimmigrants. ${ }^{167}$

Although an immigrant may have access to some public benefits after admission to the United States (and full access after naturalization), any alien deemed "likely at any time to become a public charge" may be excluded from admission into the United States. ${ }^{169}$ Under implementing regulations, consular officers presume an alien to be ineligible if the alien's expected income falls below poverty guidelines. ${ }^{169}$ Consular officers also consider other evidence, including the alien's education, skills, and assets, such as real estate, stocks, and bonds. ${ }^{170}$ Based on such evidence, consular officers have broad

${ }^{166}$ Permanent resident aliens may sponsor their spouses, children (under the age of 21), unmarried sons, and unmarried daughters for immigrant visas subject to quotas. See 8 U.S.C. $\$ 1153$ (a) (2) (1994). Once an immigrant naturalizes as a U.S. citizen, then, like other citizens, the immigrant may sponsor a spouse, children, and parents, who can obtain immigrant visas available for "immediate relatives" without quantitative limits. See id. $\S 1151$ (b) (2) (A)(i). All U.S. citizens may also sponsor their "unmarried sons or daughters," $i d$. $\S 1153(\mathrm{a})(1)$, "married sons or married daughters," id. $\S$ 1153 (a) (3), and "brothers or sisters," $i d . \S 1153$ (a) (4), for immigrant visas, with each category subject to quotas.

${ }_{167}$ See id. $\$ 1101(\mathrm{a})(15)(\mathrm{H})$.

IG Id. § 1182(a)(4); see also LEGOMSKY, supra note 95, at 348 ("Over the years, the public charge provision has become the single most common affirmative substantive basis for denials of both immigrant and nonimmigrant visas ...." (footnotes omitted)); Study, Consular Discretion in the Immigrant Visa-Issuing Process, 16 SAN DIEGO L. REV. 87, 113 (1978) ("The public charge provision ... is responsible for the greatest number of immigrant visa refusals. In $1975, \ldots$ consular officers relied on the public charge provision to deny visas in almost sixty percent of all refusals." (footnotes omitted)). Furthermore, if an alien becomes a public charge within five years after entry into the United States as a result of "causes not affirmatively shown to have arisen since entry," then the alien may be deported. 8 U.S.C. $\$ 1251$ (a)(5) (1994).

${ }^{109}$ See 22 C.F.R. $\$ 40.41$ (d) (1996) ("An immigrant visa applicant relying solely on personal income to establish eligibility... who does not demonstrate an annual income above the income poverty guidelines ... shall be presumed ineligible ....").

${ }^{170}$ See CARLINER ET AL., supra note 82, at 215 ("The standard applied by the authorities involves an analysis of the totality of the alien's circumstances. Factors that may be considered include age, health, past and current income, education, and job skills." (footnote omitted)); James A.R. Nafziger, Review of Visa Denials by Consular Officers, 66 WASH. L. REV. 1, 18 (1991) ("[T] he controlling question is ... whether, taking account of his or her total estate and income potential, the applicant can avoid becoming a public charge." (footnote omitted)). Congress made these factors explicit in the statute in 1996. 
powers to screen out immigrants expected to have a negative effect on the public treasury. ${ }^{171}$ This exclusion ground serves to ensure that family-based immigration as well as employment-based immigration is likely to have a net positive effect on the economic welfare of natives. $^{172}$ In fact, U.S. Census data indicate that immigrants earn about the same income per household that natives earn. ${ }^{173}$ Even before Congress enacted new restrictions on immigrant access to public benefits in 1996, the most careful empirical studies indicated that employment-based and family-based immigrants admitted under our immigration laws have had a positive effect on the public treasury: that is, they have paid more in taxes than they have consumed in public entitlements. ${ }^{174}$ If the new welfare law has the effects predicted by

See Illegal Immigration Reform and Immigrant Responsibility Act of 1996, Pub. L. No. 104-208, sec. 531 (a), 110 Stat. 3009 (to be codified at 8 U.S.C. 1182(a) (4) (B) (i)).

171 "All that is required of INS [Immigration and Naturalization Service] and consular officers is that they believe that the person who is seeking permission to enter the United States is 'likely' to become a public charge at some distant point in the future." Boswell, supra note 82, at 1483 (footnote omitted) (also noting "the virtual nonreviewability of the consular officers' decisions").

${ }^{172}$ In fact, Borjas finds that immigrants tend to sponsor relatives who are even more skilled than the sponsor: "[E]arly links in the immigration chain actually have less education and lower wages than subsequent links in the chain." BORJAS, FRIENDS OR STRANGERS, supra note 36, at 194. "The first link in the immigration chain is not, on average, the person who is most successful in the labor market, but is in fact the person who is the least successful." Id. at 195. The first link, however, need not be an employment-based immigrant; those admitted as refugees can also sponsor relatives for immigrant visas.

${ }^{173}$ In 1990 , households with immigrant heads were $8.4 \%$ of all households and received $8.3 \%$ of all nonwelfare income in the United States. See Borjas, Economics of Immigration, supra note 36, at 1705 tbl.15; see also id. at 1705 n.36 ("Even though the typical immigrant worker earns less than the typical native, immigrants as a group do not have a disproportionately low share of non-welfare income. This discrepancy is explained by the fact that immigrants have larger labor force participation rates than natives.").

${ }^{174}$ The Urban Institute, for example, concludes that immigrants pay at least $\$ 25$ billion more in taxes than they impose in social service costs in one year. See FIX \& PASSEL, supra note 24, at 60. This calculation reveals a surplus even though it includes the costs of public education for immigrant children without including the taxes that these children are expected to pay in the future. See Sykes, supra note 7, at 175 ("A proper accounting of the effect of immigrants on natives through ... the public sector would account for all taxes paid by immigrants over their life span and ... all services received by them through the public sector over their life span ...."). This surplus is also striking because the calculation includes not only employment-based and family-based immigrants but also refugees and illegal immigrants, who tend to be less educated and poorer than employment-based and family-based immigrants. See FIX \& PASSEL, supra note 24 , at $5,31,34$. Those seeking admission as refugees are not subject to the "public charge" exclusion ground. See 8 U.S.C. $\$ 1157$ (c)(3) (1994). As Michael Fix and Jeffrey Passel note: "The only major immigrant population eligible to participate broadly in the 
its proponents, then this positive effect on the public treasury will increase: the new restrictions would not only reduce the transfers paid to individual immigrants but also discourage the immigration of lowincome aliens. ${ }^{175}$

nation's welfare state from date of entry is refugees." FIX \& PASSEL, supra note 24, at 63. Their data indicate that refugees receive welfare at far higher rates than other immigrants. See id. at 65 fig.21; see also id. at 58 ("When refugees are excluded, it becomes clear that immigrants of working age are considerably less likely than natives of working age to receive welfare.").

On the other hand, the Urban Institute's estimate does not include any imputations for congestion externalities for public goods like roads. George Borjas performs a "back-of-the-envelope calculation" suggesting that immigrants (including refugees and illegal immigrants) imposed a net cost of $\$ 16.2$ billion on the public sector in 1990 , but only after assuming that the marginal cost of providing all government services is equal to the average cost of those services. Borjas, Economics of Immigration, supra note 36 , at 1707; see id. at 1706 tbl.16. This assumption is inappropriate for many government services, such as national defense, which are pure public goods: the marginal cost of providing these services to an immigrant is zero. In 1990, the federal government spent over $\$ 299$ billion on national defense, the single largest expenditure identified by the U.S. Office of Management and Budget, accounting for $24 \%$ of federal outlays. See U.S. DEP'T OF COMMERCE, STATISTICAL ABSTRACT OF THE UNITED STATES 1993, at 332 tbl.514 (113th ed. 1993). Borjas implicitly assumes that immigrants caused these defense outlays to rise in proportion to their $\mathbf{8 \%}$ share of the population, see Borjas, Economics of Immigration, supra note 36 , at 1705 tbl.15, costing about $\$ 24$ billion. Thus, excluding national defense alone from the Borjas calculation changes the net cost to a net benefit.

Furthermore, Borjas arrives at his figure by assuming a low tax yield (30\%) from immigrant's nonwelfare income. See id. at $\mathbf{1 7 0 6}$ tbl.16. Given the similarity in income per household between immigrants and natives, there is no apparent reason to assume a much greater tax yield from natives than from immigrants. See id. at 1705 ("In 1990, immigrants received 8.3 percent of all non-welfare income (about the same as their population proportion)."). Using the figures Borjas provides and applying the same assumptions and the same procedure to the nonwelfare income of natives indicates that natives impose a net cost of over $\$ 73$ billion on the public sector. The Borjas procedure applied to any group is biased in favor of finding a net cost, in part because government revenues failed to cover expenditures in 1990 (as is often the case). See U.S. DEP'T OF COMMERCE, supra, at 292 tbl.467. The burden of this government debt is passed forward to future generations of taxpayers, which include the descendants of immigrants as well as the descendants of those who are currently natives. Furthermore, it is hard to see how the low revenue figures Borjas uses can produce the $\$ 2$ trillion in revenue actually collected in 1990 to pay for the expenditures that Borjas expects to finance. See id. Nevertheless, he repeatedly cites this "\$16 billion net loss" figure, Borjas, supra note 35 , at 9 , claiming that "immigrants impose a $\$ 16$ billion annual burden on native taxpayers," Borjas, supra note 53, at 77.

${ }^{175}$ See Robert Pear, Clinton to Sign Welfare Bill that Ends U.S. Aid Guarantee and Gives States Broad Power, N.Y. TIMES, Aug. 1, 1996, at Al (reporting that the welfare bill is expected to save $\$ 55$ billion over six years); Lena $\mathrm{H}$. Sun, Legal Immigrants Will Face Harsher Welfare Deadlines, Advocacy Groups Say, WASH. POST, Aug. 1, 1996, at A8 (estimating that nearly $40 \%$ of the savings under the welfare bill would come from denying aid to immigrants). But see infra note 178 (suggesting that the new restrictions may also discourage some skilled immigration). 
To avoid the "public charge" exclusion ground, sponsoring relatives have often provided affidavits of support and evidence of their own incomes in order to gain the admission of the sponsored alien. ${ }^{176}$ Thus, when the sponsored alien has had a low income, the income of the sponsor would become relevant: this exclusion ground has in effect limited the right to sponsor low-income relatives to those petitioners with adequate levels of income. In short, the "public charge" provision has served to ensure not only that family-based immigrants impose little burden on the public sector but also that the formal right to petition for low-income family members is likely to prove valuable in effect only for immigrants with relatively high incomes. ${ }^{177}$

${ }^{176}$ See, e.g., Kohama, 17 I. \& N. Dec. 257 (1978); see also CARLINER ET AL., supra note 82, at 215 ("Aliens with income below the poverty guidelines may still avoid exclusion on public charge grounds by submitting affidavits of support from persons who undertake a moral obligation to support the alien."). Furthermore, the income and assets of a sponsor signing any affidavit of support are generally deemed to be available to the alien beneficiary for a certain number of years after entry when determining the eligibility of the alien for certain public entitlements. See 42 U.S.C. $\$ \S 615$ (a) (deeming for five years for Aid to Families with Dependent Children), 1382j(a) (1994) (deeming for three years for Supplemental Security Income); 7 U.S.C. \$ 2014(i) (1994) (deeming for three years for food stamps). Thus, affidavits of support will render otherwise eligible aliens ineligible for public benefits. Both houses of Congress passed immigration bills in 1996 that would have extended "deeming" to all federal means-tested programs. See House Approves Immigration Bill After Removing Legal Immigration Restrictions, supra note 22, at 354; Senate Approves Omnibus Immigration Bill After Removing Exclusion Provisions, supra note 22, at 608 . These bills would have also extended the "deeming" period, in general applying "deeming" until the applicant obtains U.S. citizenship. See Immigration Bills Head to House Senate Conference; Battles Over Particulars Loom, 73 INTERPRETER RELEASES 678, 680 (1996). Faced with opposition from the Clinton administration, however, Republicans in Congress deleted these "deeming" provisions from the immigration bill eventually enacted.

177 Canada allows an independent (self-supporting) immigrant, either as a permanent resident or as a citizen, to sponsor an even wider set of relatives than possible under U.S. law, but also places weight on economic criteria. Independent immigrants can bring not only their spouses and unmarried minor children but also grandparents. The sponsor must agree to sign an undertaking of support and be capable of supporting these sponsored relatives as dependents. See Kubat, supra note 93, at 29-30. An immigrant may also nominate other relatives-not only brothers, sisters, sons, and daughters, but also more distant relatives, including uncles, aunts, nephews, nieces, grandsons, and granddaughters-as "assisted relatives" if the nominating immigrant is able to support them so that they do not become public charges. See id. at 29-31; Legal Immigration Reform Proposals: Hearing Before the Subcomm. on Immigration and Claims of the Comm. on the Judiciary, House of Representatives, 104th Cong., 154, 160 (1995) (prepared statement of John Guendelsberger). Sponsorship of any relative "requires an annual income above the poverty level and a pledge that the sponsored [relative] will not receive welfare or government health services for five years after entry." Id. Canada evaluates assisted relatives as independent immigrants under a "point system," but awards them bonus points for their status as assisted relatives, and still more points if accompanied by an undertaking of assistance, which enables them to pass with lower scores on economic criteria, such as education, specific vocational preparation, expe- 
Consequently, the availability of these family-based visas serves as an incentive for skilled aliens in particular to choose to accept employment and residence in the United States. ${ }^{178}$

In 1996, Congress imposed still more stringent requirements for family sponsorship that will further limit access to these visas and will tend to reserve them for sponsors with relatively high incomes. The Illegal Immigration Reform and Immigrant Responsibility Act of 1996 requires virtually all family-based immigrants to submit an affidavit of support. $^{179}$ An affidavit of support must now be a contract enforceable against the sponsor not only by the sponsored alien but also by a federal, state, or local agency seeking reimbursement for benefits provided to the sponsored alien under a means-tested entitlement program. ${ }^{180}$ The affidavit must bind the sponsor "to provide support to maintain the sponsored alien at an annual income that is not less than 125 percent of the Federal poverty line." ${ }^{\text {181 }}$ The sponsor must

rience, and arranged employment. See id. at 160-61; García y Griego, supra note 93, at 126 tbl.4.2; Kubat, supra note 93, at 32 tbl.2.

${ }^{178}$ To the extent a skilled alien anticipates sponsorship of low-income relatives for immigration to the United States, any public entitlements the sponsored relatives anticipate may function as vicarious or indirect subsidies for the skilled sponsor. Indeed, as Congress recently reduced immigrant access to public entitlements, see supra Part I.G, it explicitly sought to shift the burden of supporting needy immigrants from the public sector to sponsoring relatives. See Personal Responsibility and Work Opportunity Reconciliation Act of 1996, Pub. L. No. 104-193, sec. 400(2) (A), 110 Stat. 2105, 2260 (to be codified at 8 U.S.C. $\$ 1601(2)(A)$ ) (stating that aliens should "not depend on public resources to meet their needs, but rather rely on their own capabilities and the resources of their families, their sponsors, and private organizations"). By reducing the indirect subsidy (that is, the implicit negative tariff) for skilled sponsors, however, these new rules may reduce the incentives for skilled immigration, and thus could be contrary to the national economic interest.

173 The new law states that any alien seeking admission as a family-based immigrant, with only very narrow exceptions, is excludable unless the alien's sponsor executes an affidavit of support. See Illegal Immigration Reform and Immigrant Responsibility Act of 1996, Pub. L. No. 104-208, sec. 531(a), § 212(a)(4)(C), 9B U.S.C.C.A.N. (110 Stat. 3009) 1570, 1779 (Nov. 1996) (to be codified at 8 U.S.C. $\$ 1182(a)$ (4)(C)).

${ }^{180}$ See id. sec. 551 (a), $\S 213 A$, 9B U.S.C.C.A.N. (110 Stat. 3009) at 1780 (to be codified 8 U.S.C. $\$ 1183 \mathrm{a}$ ). Furthermore, under welfare legislation enacted by Congress that same year, if the immigrant beneficiary of such an affidavit later applies for "any Federal means-tested public benefits," then the immigrant's income and resources shall be "deemed" to include the income and resources of the sponsor, until the beneficiary either obtains U.S. citizenship or has worked for a sufficient period of time (" 40 qualifying quarters"). Personal Responsibility and Work Opportunity Reconciliation Act, sec. 421,110 Stat. at 2270 (to be codified at 8 U.S.C. $\$ 1631$ ). Thus, "deeming" will render otherwise eligible immigrants ineligible for public benefits.

${ }^{181}$ Illegal Immigration Reform and Immigrant Responsibility Act, sec. 551(a), $\S 213 A(a)(1)(A), 9 B$ U.S.C.C.A.N. (110 Stat. 3009) at 1781 (to be codified at 8 U.S.C. $\S 1183 a(a)(1)(A))$. 
demonstrate "the means to maintain" at least this level of income for "a family unit of a size equal to the number of members of the sponsor's household (including family and non-family dependents) plus the total number of other dependents and aliens sponsored by that sponsor. ${ }^{n 182}$ To meet this requirement, a sponsor must provide certified copies of the sponsor's federal income tax returns for three years. ${ }^{183}$ These requirements will not only improve still further the effect of family-based immigrants on public coffers but also deter or preclude those of modest means from sponsoring relatives for immigration. ${ }^{184}$ These requirements also ensure that the availability of family-based immigration visas will prove most valuable for the immigrants with the most wealth, because the number of relatives an immigrant can sponsor will be directly related to the immigrant's wealth.

Although restrictionists have proposed drastic cuts in family-based immigration, citing the national interest, ${ }^{185}$ these cuts may in fact reduce the economic welfare of natives by reducing the incentives for skilled immigration and by excluding valuable workers and taxpayers. Indeed, given the alternative of qualitative restrictions like the "public charge" exclusion ground as a device for regulating immigration, it is doubtful that quantitative restrictions on family-based immigration serve a useful purpose at all in the pursuit of national economic wel-

${ }^{182} I d . \S 213 \mathrm{~A}(\mathrm{f})(1)(\mathrm{E}),(6)$ (A) (iii), 9B U.S.C.C.A.N. (110 Stat. 3009) at 1785, 1787 (to be codified at 8 U.S.C. $\$ 1183 \mathrm{a}(\mathrm{f})(\mathrm{I})(\mathrm{E}),(6)(\mathrm{A})(\mathrm{iii})$ ). The law allows a sponsor who fails to meet this requirement to recruit another sponsor who can satisfy the requirement by accepting joint and several liability. Id. $\S 213 \mathrm{~A}(\mathrm{f})(2),(5), 9 \mathrm{~B}$ U.S.C.C.A.N. (110 Stat. 3009 ) at $1785-86$ (to be codified at 8 U.S.C. $\S 1183(\mathrm{f})(2),(5)$ ). This legal liability, however, is likely to deter all but the closest relatives from serving as sponsors.

${ }^{189}$ Id. $\$ 213 \mathrm{~A}(\mathrm{f})(6)(\mathrm{A})(\mathrm{i}), 9 B$ U.S.C.C.A.N. (110 Stat. 3009) at 1786 (to be codified at 8 U.S.C. $\S 1183 a(f)(6)(A)(i))$.

${ }^{184}$ Preliminary research sponsored by the Immigration and Naturalization Service found that $30 \%$ of those who sponsored relatives for immigration in 1994 had incomes below the new standard. See Celia W. Dugger, Immigrant Study Finds Many Below New Income Limit, N.Y. TIMES, Mar. 16, 1997, § 1, at 1 . Another study by the Urban Institute found that $40 \%$ of immigrant families and $26 \%$ of natives in the United States in 1993 had incomes below the new standard. See id.

${ }^{185}$ Vernon Briggs, for example, has proposed elimination of the visa category for siblings of U.S. citizens and significant reductions in the other family-based categories. See BRIGGS, supra note 29, at 247. Similarly, the Jordan Commission recommended the complete elimination of most family-based admission categories, including not only siblings of U.S. citizens but also adult sons and daughters of U.S. citizens and of legal permanent residents. See JORDAN COMM'N, supra note 15, at 70-71. The Smith and Simpson bills sought to implement these recommendations. See H.R. 2202, 104th Cong. (1995); S. 1394, 104th Cong. (1995). 
fare. Liberalization or elimination of these quotas would probably serve the interest of natives better than cuts in these quotas. ${ }^{180}$

\section{Distributive Justice}

The policies described above would maximize the total economic benefits for natives from immigration. While I have addressed how to maximize the total wealth of natives, I have not addressed the distribution of that wealth among natives. Immigration not only expands wealth, but also can have important distributive effects.

Those natives who must compete with immigrants in the labor market may find that immigration reduces their real income. Empirical studies, however, consistently find that immigration has only a weak effect on native wages. ${ }^{187}$ On the other hand, even if present levels of immigration have little effect on real wages in the United States, a more liberal immigration policy could produce significant effects. ${ }^{188}$ Thus, much of the support for immigration restriction is

${ }^{186}$ Michael Trebilcock criticizes the use of "total intake numbers or caps on categories of immigrants . . . largely plucked out of the air," arguing:

[I]f we collectively support the admission of close relatives of existing citizens or permanent residents, we should simply let them in, with minimum requirements pertaining to health and security checks, and so on, particularly if, through family sponsorship, newly admitted family members must look for a substantial period of time principally to their families for assistance, and not to noncontributory public assistance programs ....

Michael J. Trebilcock, The Case for a Liberal Immigration Policy, in JUSTICE IN IMMIGRATION, supra note 7, at 219, 239; see id. at 242 ("I reemphasize my opposition to arbitrary caps on the total immigrant intake or on categories of applicants within the total intake. If input criteria are designed and applied sensibly, we should live with whatever numeric outcomes emerge in administering these input criteria."); see also John Guendelsberger, Implementing Family Unification Rights in American Immigration Law: Proposed Amendments, 25 SAN DIEGO L. REV. 253, 254 (1988) (arguing that "national interests could be protected by means which do not impede family unity" and that "Congress should eliminate the numerical ceilings on entry of the spouses and minor children of permanent resident aliens").

187 "Despite the popular belief that immigrants have a large adverse impact on the wages and employment opportunities of the native-born population, the literature on this question does not provide much support for this conclusion." Friedberg \& Hunt, supra note 102, at 42 . "Even those natives who should be the closest substitutes with immigrant labor have not been found to suffer significantly as a result of increased immigration." Id.; see Borjas, Economics of Immigration, supra note 36, at 1697 (surveying the empirical studies and observing a "numerically weak relationship between native wages and immigration ... across all types of native workers, white or black, skilled or unskilled, male or female").

${ }^{183}$ Borjas claims: "Ironically, even though the debate over immigration policy views the possibility that immigrants lower the wage of native workers as a harmful consequence of immigration, the economic benefits from immigration arise only 
protectionist in nature: restrictionists often cite the need to protect U.S. workers from foreign competition. ${ }^{189}$ The requirement of labor certification, in particular, is designed to ensure that immigrants do not "take jobs away" from U.S. workers or drive down their wages.

Protectionist policies in the immigration context, however, are inappropriate in much the same way that they are inappropriate in the context of international trade in goods. Standard trade theory predicts that trade along the lines of comparative advantage with nations more abundant in labor than the United States will reduce the real wages of U.S. workers. ${ }^{190}$ This distributive effect, however, is not sufficient justification for protectionism.

If we wish to protect workers from these distributive effects, the appropriate response is not protectionism but redistribution. Opti-

when immigrants do lower the wage of native workers." Borjas, supra note 35, at 10-11. This claim, however, refers only to the immigration surplus enjoyed by natives through the private sector in labor markets with native workers. If only immigrant workers find certain jobs worth taking, then natives can gain from immigration in these markets without driving down the wages of any native workers. Furthermore, if immigrants generate a benefit for the public sector in the form of tax revenues, then natives can gain from immigration even if there is no effect on wages at all.

Borjas estimates that the "immigration surplus" enjoyed by the private sector in the United States is "relatively small" ( $\$ 7$ billion per year), based on labor demand elasticity estimates suggesting that a $10 \%$ increase in the labor supply would reduce wages by only $3 \%$. Id. at 7. This calculation, however, assumes that the domestic labor supply is perfectly inelastic, so that it estimates only the benefits of the "consumption effect" on the demand side from lower wages, not the benefits associated with the "production effect" on the supply side. See id. at $6 \mathrm{n} .2$. Furthermore, higher levels of immigration would bring a more than proportionate increase in the immigration surplus because the marginal benefits of immigration increase with the quantity of immigration: more of the decline in domestic wages comes at the expense of immigrant workers rather than natives. Therefore, we would expect a more liberal policy to produce much larger benefits for natives. Finally, this calculation does not include the role of the public sector: taxes can greatly increase the benefit to natives from a given amount of immigration by capturing some of the (much larger) gains from trade enjoyed by immigrants as quota rents. If immigration exerts only mild downward pressure on wages, then these quota rents would be especially large.

${ }^{189}$ See ECONOMIC REPORT OF THE PRESIDENT, supra note 4, at 222 ("Arguments supporting the restriction of immigration to protect American jobs are similar to those favoring protectionism in international trade ....").

${ }_{190}$ The standard Heckscher-Ohlin model of international trade assumes two countries with the same technology and consumer tastes, but different endowments of two factors of production. For example, countries may differ in their endowments of capital and labor, such that their capital/labor ratios are different. Residents in each country consume two goods, one more labor intensive, the other more capital intensive. The Stolper-Samuelson theorem predicts that opening trade between these two countries will cause the real wage to fall in the capital-abundant country. See, e.g., CAVES \& JONES, supra note 43, at 108-17 (presenting the Heckscher-Ohlin model and concluding with the Stolper-Samuelson theorem). 
mal policies would liberalize both trade and immigration insofar as they increase the total wealth of natives. As long as these policies increase total wealth, then those who gain from these policies can compensate those who lose and still be better off. That is, those who gain by paying lower wages, or by buying products and services at lower cost, can afford to pay enough to compensate those whose wages fall relative to prices. Redistributive policies can shift the costs of liberalized trade and immigration to the beneficiaries of liberalization.

This redistribution would produce some costly distortions, but the deadweight loss of protectionism would be greater than the deadweight loss from redistributive taxes. That is, protectionism is less efficient than the tax system in producing a desirable distribution of income. Steven Shavell and Louis Kaplow have shown that we can always replace an economically inefficient rule with an efficient rule without making any income class worse off, provided that we make the appropriate adjustments in income taxes. ${ }^{191}$ For example, if the immigration of guestworkers reduces the wages of unskilled workers, then raising taxes on those with higher incomes and reducing taxes on those with the lowest can leave all classes of natives better off than they would be in the absence of immigration. ${ }^{192}$ We can achieve this redistribution by expanding programs already in use under the existing U.S. income tax system: we could increase the earned income tax credit and liberalize its eligibility requirements, for example, to supplement the income of the working poor if liberalized immigration drives down their real wages. We can thereby reduce deadweight loss while still redistributing the same wealth that we currently redistribute through costly protectionism.

${ }^{191}$ See Louis Kaplow \& Steven Shavell, Why the Legal System Is Less Efficient Than the Income Tax in Redistributing Income, 23 J. LEGAL STUD. 667, 669 (1994) ("[E]ven though the income tax distorts work incentives, any regime with an inefficient legal rule can be replaced by a regime with an efficient legal rule and a modified income tax system designed so that every person is made better off."); Steven Shavell, A Note on Efficiency vs. Distributional Equity in Legal Rulemaking: Should Distributional Equity Matter Given Optimal Income Taxation?, 71 AM. ECON. REV. PAPERS \& PROC. 414 (1981). As Kaplow and Shavell explain, "using legal rules to redistribute income distorts work incentives fully as much as the income tax system-because the distortion is caused by the redistribution itself-and also creates inefficiencies in the activities regulated by the legal rules." Kaplow \& Shavell, supra, at 667-68.

${ }^{192}$ See Chiswick, supra note 104, at 107 ("Through taxes and transfers some of the gains of high-skilled workers and the owners of capital can be transferred to low-skilled native workers to make all natives at least as well off as before the low-skilled migration."). 
To maximize the welfare of natives, the United States would exclude immigrants from these redistributive programs. Otherwise, the transfers to immigrants could dissipate the economic gains to natives. In fact, excluding immigrants from transfers would be necessary if we are to ensure that each class of natives gains. ${ }^{193}$ Exclusion from transfers, however, is consistent with the immigration tariff described above. Indeed, if we admit unskilled workers as nonimmigrants, then the tariff on their labor could take the form of an income tax credit available only to citizens and legal permanent resident aliens, combined with an otherwise nondiscriminatory income tax system.

Economists have suggested immigration, international trade, and technological progress as possible causes of the growing inequality in income in the United States. ${ }^{194}$ Such an effect, however, is no more an argument for restricting immigration or international trade than it is an argument for policies designed to reduce the pace of innovation. As long as a policy increases national wealth, it can (when combined with appropriate fiscal policies) make all economic classes of natives better off.

\section{Preferences for the Ethnic Status Quo}

Some support for immigration restrictions seems to derive from fear of (or distaste for) foreigners, especially foreigners of minority

${ }^{193}$ See id. ("Suppose ... the income transfer system ... treats immigrants and natives equally.... [T] he inclusion of low-skilled aliens in the income transfer system means that a Pareto optimal transfer cannot take place. Thus, low-skilled immigration can make the native population as a whole worse off.").

[I]f immigrants are not included in the income transfer system, the increase in the aggregate income of the native population means that appropriate income redistribution policies can be devised to transfer some income from the native groups that gain, to the native groups that lose, so that no native group loses from the immigration. The welfare and tax systems can be the mechanism for this transfer. This cannot be accomplished, however, if the immigrants themselves are to be substantial recipients of income transfers ....

Chiswick, supra note 27, at 304; see Krauss \& Baumol, supra note 27, at 37 ("[A]ny attempt to improve the welfare of domestic workers (for whom guest workers are perfect substitutes) is likely to prove futile if the benefits are extended to all workers ....").

${ }^{194}$ See, e.g., Gary Burtless, International Trade and the Rise in Earnings Inequality, $33 \mathrm{~J}$. ECON. LITERATURE 800 (1995) (surveying the literature addressing whether international trade or technological change is the primary cause of rising inequality in the United States and other industrialized countries); George J. Borjas et al., On the Labor Market Effects of Immigration and Trade, in IMMIGRATION AND THE WORK FORCE, supra note 61, at 213 (estimating the share of the decline in the relative wages of high-school dropouts during the 1980s that can be attributed to immigration and international trade). 
races or ethnic groups. ${ }^{195}$ The nativist Peter Brimelow, for example, is quite explicit in his expressions of alarm regarding the racial complexion of the immigrant stream into the United States. ${ }^{196}$ One could count the satisfaction of these xenophobic or racist preferences as part of the economic welfare of natives. Immigrants might be thought to generate a negative externality insofar as they erode the "public good" of ethnic purity consumed by racists and xenophobes. Even if we were to count this "public good" as economic value, however, it need not follow that this value should receive any weight as a normative matter in the formulation of public policy. In choosing between alternative policies, we may therefore exclude them from our measure of social welfare on ethical grounds:
Utilitarians disagree about whether all pleasures (or desires or interests) are to count or only some.... Should a white racist's unhappiness at the prospect of associating with people of color be counted in the calculus of utility as an argument in favor of racial exclusion as reflected, say, in the White Australia policy? What about the desire to preserve a distinc- tive local culture as a reason for restricting immigration? ${ }^{197}$

We may deem these preferences as morally "illegitimate," in the sense that they are not legitimate grounds for imposing costs on other citizens. $^{198}$ It is telling that we normally reject such preferences as justification for racial discrimination in the domestic context, at least when the government excludes racial minorities from important opportunities. These preferences would also seem problematic as justifications for immigration restrictions. Although a full discussion of these issues is beyond the scope of this paper, an examination of the analogy between racial segregation and immigration restrictions serves to illustrate the issues raised.

${ }^{195}$ See Johnson, supra note 4, at 947 ("[T] tionist demand."); see also id. at 948 ("The current negative reaction toward illegal (and often legal) immigration is fueled at least in part by the increasing number of immigrants of color coming to the United States from developing nations.").

${ }^{196}$ See PETER BRIMElow, ALIEN NATION: COMMON SENSE ABOUT AMERICA'S IMMIGRATION DISASTER 58-73 (1995) (describing white America as caught between the "pincers" of Hispanic and Asian immigration).

197 Carens, supra note 26, at 263-64.

${ }^{139}$ See Thomas M. Scanlon, The Moral Basis of Interpersonal Comparisons, in INTERPERSONAL COMPARISONS OF WELI-BEING 17, 28 (Jon Elster \& John E. Roemer eds., 1991) ("The reasons ... for excluding ... 'antisocial' preferences ... do not assert that the fulfillment of these preferences is not good for the individuals in question. All that is asserted is that these preferences 'have no claim on us' - that is, on society-for their fulfillment."). 
To take one example of a theory of illegitimate preferences, consider Ronald Dworkin's distinction between two types of preferences: "the preferences of an individual for the consequences of a particular policy may be seen to reflect... either a personal preference for his own enjoyment of some goods or opportunities, or an extermal preference for the assignment of goods and opportunities to others, or both." that excludes blacks: "A white law school candidate might have a personal preference for the consequences of segregation, for example, because the policy improves his own chances of success, or an external preference for those consequences because he has contempt for blacks and disapproves social situations in which the races mix."200 Similarly, we may distinguish the desire for protection from foreign competition and xenophobia as distinct bases for immigration barriers.

Dworkin argues that a utilitarian calculus of social welfare should exclude external preferences:

If a utilitarian argument counts external preferences along with personal preferences, then the egalitarian character of that argument is corrupted, because the chance that anyone's preferences have to succeed will then depend, not only on the demands that the personal preferences of others make on scarce resources, but on the respect or affection they have for him or for his way of life. If external preferences tip the balance, then the fact that a policy makes the community better off in a utilitarian sense would not provide a justification compatible with the right of those it disadvantages to be treated as equals. ${ }^{20}$

By similar reasoning, xenophobic and racist preferences cannot justify immigration restrictions any more than they can justify racial segregation in the domestic context.

The nativist may object that aliens are not entitled to equal treatment. ${ }^{202}$ Given that the very notion of maximizing the economic welfare of natives through immigration policies relies on the legitimacy of putting their interests before the interests of aliens, let us accept this premise for the purposes of this discussion. Nevertheless,

${ }^{199}$ RONALD DWORKIN, TAKING RIGHTS SERIOUSLY 234 (1977).

${ }^{200}$ Id. at 234-35.

201 Id. at 235 .

${ }^{202}$ Dworkin, after all, describes the egalitarian character of utilitarianism with respect to citizens: "the utilitarian argument not only respects, but embodies, the right of each citizen to be treated as the equal of any other." Id. at 234; see id. at 236 ("That theory owes much of its popularity to the assumption that it embodies the right of citizens to be treated as equals."). 
Dworkin's objection to external preferences still applies in the immigration context. Immigration restrictions harm not only aliens but also citizens. Those citizens whose personal preferences are satisfied by immigration would suffer if we were to give weight to the external preferences of racist or xenophobic citizens. ${ }^{203}$ This outcome would be incompatible with the egalitarianism described by Dworkin, because racist or ethnocentric preferences are incompatible with the right of all citizens to equal concern and respect, regardless of race or ethnicity. ${ }^{204}$ Similarly, xenophobia - the fear or hatred of foreigners and foreign culture-is inconsistent with equal concern and respect for citizens who may share the cultural traits that the xenophobe finds disagreeable. ${ }^{205}$

Nativists may respond that their preference is neither racist nor xenophobic, but simply a matter of personal taste. Perhaps the nativist simply prefers to be surrounded by others who share the same culture and the same values, and fears becoming surrounded by those who seem foreign and unfamiliar. But can we distinguish this associa-

${ }^{203}$ Similarly, mandatory racial segregation in the domestic context harms individuals of all races. In Buchanan v. Warley, 245 U.S. 60 (1917), the Supreme Court struck down a law preventing blacks from buying homes in white neighborhoods, in order to protect the right of a white plaintiff to enforce a contract for the sale of a house to "a person of color." Id. at 81 (vindicating "the right of a white man to dispose of his property if he saw fit to do so to a person of color").

${ }_{204}$ Rosberg argues that the exclusion of aliens from the United States on the basis of race or national origin should be subject to strict judicial scrutiny,

not because of the injury to the aliens denied admission, but rather because of the injury to American citizens of the same race or national origin who are stigmatized by the classification. When Congress declares that aliens of Chinese or Irish or Polish origin are excludable on the grounds of ancestry alone, it fixes a badge of opprobrium on citizens of the same ancestry.... Except when necessary to protect a compelling interest, Congress cannot implement a policy that has the effect of labeling some group of citizens as inferior to others because of their race or national origin.

Rosberg, supra note 113 , at 327 . The restriction of immigration in general, however, has the same stigmatizing effect when the restriction is justified as an indirect means of achieving the same invidious objective: controlling the population of disfavored ethnic groups.

${ }^{205}$ The right of citizens to be treated as equals, however, does not rule out all forms of discrimination. As Dworkin notes, admission to law school based on intelligence, for example, "relies ... upon the law school's own judgment, right or wrong, that intelligent lawyers are more effective in satisfying personal preferences of others, such as the preference for wealth or winning law suits." DwORKIN, supra note 199, at 238. Similarly, an immigration policy may legitimately discriminate among aliens based on their skills. Nor would the exclusion of external preferences rule out discrimination against aliens as long as that discrimination could be justified on the basis of personal preferences. The preceding economic analysis, for example, has presented a case for an immigration tariff without relying on external preferences. 
tional preference from intolerance-the desire not to encounter those who are different? Would the desire of residents to maintain a white neighborhood, because they prefer its homogeneous culture or simply value the familiar status quo, justify either laws to exclude blacks or judicial enforcement of racially restrictive covenants? ${ }^{206}$ Would we accept these associational preferences as a justification for the exclusion of ethnic minorities from a law school? $?^{207}$

Furthermore, it is unclear whether such associational preferences can provide much support for immigration restrictions. The less restrictive means for addressing these concerns would be voluntary private discrimination against immigrants or segregation mandated at

${ }^{200}$ See Shelley v. Kraemer, 334 U.S. 1 (1948) (holding that the Fourteenth Amendment prohibits states from enforcing racially restrictive covenants); Buchanan v. Warley, 245 U.S. 60 (1917) (holding that the Fourteenth Amendment prohibits laws that forbid blacks to reside in white neighborhoods). Would we consider such covenants or laws any more acceptable if they excluded aliens rather than racial minorities from local communities? Why should the same intolerant impulse to exclude be any more legitimate when the exclusion is on a national scale rather than at the local level? tions:

${ }_{207}$ Again, Dworkin's objections to segregation apply readily to immigration restric-

Sometimes personal and external preferences are so inextricably tied together, and so mutually dependent, that no practical test for measuring preferences will be able to discriminate the personal and external elements in any individual's overall preference. That is especially true when preferences are affected by prejudice. Consider, for example, the associational preference of a white law student for white classmates. This may be said to be a personal preference for ... one kind of colleague rather than another. But it is a personal preference that is parasitic upon external preferences: except in very rare cases a white student prefers the company of other whites because he has racist ... convictions, or because he has contempt for blacks as a group. If these associational preferences are counted in a utilitarian argument used to justify segregation, then the egalitarian character of the argument is destroyed just as if the underlying external preferences were counted directly.... In any community in which prejudice against a particular minority is strong, then the personal preferences upon which a utilitarian argument must fix will be saturated with that prejudice; it follows that in such a community no utilitarian argument purporting to justify a disadvantage to that minority can be fair.

DWORKIN, supra note 199, at 236-37; see Mark Tushnet, Immigration Policy in Liberal Political Theory, in JUSTICE IN IMMIGRATION, supra note 7, at 147, $157 \mathrm{n} .20$ ("[T] he value-based exclusion might serve as a mask for a race-based exclusion: we might say that some people are 'not like us' because of their values when we really believe that they are 'not like us' because of their race."); Johnson, supra note 78, at 1543 ("Great difficulties in attempting to separate legitimate from illegitimate concerns exist because of, among other things, the unconscious nature of much racism in U.S. society." (footnote omitted)); see also Charles R. Lawrence III, The Id, the Ego, and Equal Protection: Reckoning with Unconscious Racism, 39 STAN. L. REV. 317 (1987) (arguing that unconscious racism is ubiquitous and should be taken into account in identifying invidious racial discrimination). 
the local level. Yet we normally reject associational preferences as a justification for such discrimination against minorities. If we would reject such associational preferences as a reason to exclude immigrants from local schools or neighborhoods, then why should we accept them as a reason to exclude them from an entire country, where the claim of impact on one's personal associational interests seems far more remote and tenuous?

Although we often allow private clubs to discriminate, in deference to their associational interests, we usually reject such discrimination when mandated by the state. ${ }^{208}$ Even if we identify legitimate associational interests that do not derive from intolerance, it seems difficult to explain why we must protect these interests through discrimination mandated by the government on a national scale rather than through less restrictive voluntary discrimination in the private sphere. ${ }^{209}$ What legitimate reason can there be for preferring ethnic or cultural homogeneity on a national scale?

Nativists may base their preference for an ethnically homogenous nation not on prejudice or associational preferences but on fears that a more multiracial society would lead to ethnic strife and instability. ${ }^{210}$ These types of concerns, however, are also problematic, because they may also be parasitic upon racism and xenophobia. We ordinarily reject these concerns as justifications for compulsory racial segregation in the domestic context. ${ }^{211}$ As Dworkin explains:

${ }^{209}$ Carens notes the "deep tension between the right of freedom of association and the right to treatment" and suggests that "in the private sphere freedom of equal association prevails and in the public sphere equal treatment does." Carens, supra note 26, at 267. He observes that "it is clear that clubs are normally at one end of the scale and states at the other" and concludes: "When the state acts it must treat individuals equally." Id. at 268; see WALZER, supra note 60 , at 45 ("[A]dmission to a country does not entail the kinds of intimacy that could hardly be avoided in the case of clubs and families."); Stephen H. Legomsky, Immigration, Equality, and Diversity, 31 CoLUM. J. TRANSNAT'L L. 319, 331 (1993) (“[T] here would seem to be even less room for governmental favoritism toward particular ethnic groups than for analogous private sector favoritism.").

${ }^{209}$ See WALZER, supra note 60, at 44 ("Perhaps we should insist upon open countries and permit closure only in non-territorial groups. Open neighborhoods together with closed clubs and families: that is the structure of domestic society. Why can't it, why shouldn't it be extended to the global society?").

${ }^{210}$ See, e.g., BRIMELOW, supra note 196, at 123-33, 207.

211 In Buchanan v. Warley, 245 U.S. 60 (1917), the Supreme Court struck down a law forbidding blacks to occupy homes in white neighborhoods, rejecting the justification "that this proposed segregation will promote the public peace by preventing race conflicts." Id. at 81. 
It does not matter ... whether external preferences figure in the justification of a fundamental policy or in the justification of derivative policies designed to advance a more fundamental policy. Suppose Texas justifies segregation by pointing to the apparently neutral economic policy of increasing community wealth, which satisfies the personal preferences of everyone for better homes, food, and recreation. If the argument that segregation will improve community wealth depends upon the fact of external preference; if the argument notices, for example, that because of prejudice industry will run more efficiently if factories are segregated; then the argument has the consequence that the black man's personal preferences are defeated by what others think of him. ${ }^{212}$

Similarly, because of the racism or xenophobia of natives, society might function less well if it becomes more diverse. This concern, however, is troubling as a reason to exclude immigrants, because it allows racism and xenophobia to override more legitimate preferences: to base our immigration laws on these concerns gives effect to racist and xenophobic preferences for ethnic purity. ${ }^{213}$

Nativists also raise general concerns about the cultural consequences of immigration, worrying about the cultural traits of immigrant groups and their implications for economic success. ${ }^{214}$ We may worry, however, that these arguments are often tainted by prejudice. ${ }^{215}$ Bias against foreigners is widespread enough that we should regard with suspicion claims regarding the adverse effects of immigration on the national culture. ${ }^{216}$

${ }^{212}$ DWORKIN, supra note 199, at 237.

${ }^{219}$ In Palmore v. Sidoti, 466 U.S. 429 (1984), the Supreme Court held that a state cannot deny a divorced mother custody of her child on the basis of her interracial remarriage, even if the persistence of racial prejudice in society implies that "a child living with a stepparent of a different race may be subject to a variety of pressures and stresses not present if the child were living with parents of the same racial or ethnic origin." Id. at 433. The Court stressed: "Private biases may be outside the reach of the law, but the law cannot, directly or indirectly, give them effect." Id.

${ }^{214}$ See, e.g., BRIMELOW, supra note 196, at 178-81.

${ }^{215}$ Jody Armour notes that "[t] he tendency of individuals to credit only those statistics and images which confirm their preexisting biases exacerbates ... irrational influences" such as "cultural stereotypes" and "racial antagonisms." Jody D. Armour, Race Ipsa Loquitur: Of Reasonable Racists, Intelligent Bayesians, and Involuntary Negrophobes, 46 STAN. L. REV. 781, 791 (1994). Thus, Armour worries that "factfinders will inevitably exaggerate the weight properly accorded to" facts that are consistent with these prior biases. Id.

${ }^{216}$ Again, Dworkin's comments on race are instructive:

Utilitarian arguments that justify a disadvantage to members of a race against whom prejudice runs will always be unfair arguments, unless it can be shown that the same disadvantage would have been justified in the absence of the prejudice. If the prejudice is widespread and pervasive, as in fact it is in the case of blacks, that can never be shown. 
Suppose, however, that we identify preferences for the ethnic or cultural status quo that would survive in the hypothetical absence of intolerance. Perhaps we can have equal regard for those of all races and nationalities, but still prize an ethnically homogeneous nation for its own sake, not out of intolerance. We may prefer the ethnic status quo because we value the existing national culture and want to prevent change in its values. For example, Walzer defends the power of "the sovereign state... to make its own admissions policy, to control and sometimes restrain the flow of immigrants" on the basis of communitarian values: "The distinctiveness of cultures and groups depends upon closure .... If this distinctiveness is a value, as most people... seem to believe, then closure must be permitted somewhere." ${ }^{217}$

We might nevertheless deem it inappropriate to give weight to the preferences of some citizens for a particular national culture in a utilitarian calculation of costs and benefits. ${ }^{218}$ Indeed, in a society like

DWORKIN, supra note 199, at 237.

217 WALZER, supra note 60 , at 39 . Walzer explains that we should prefer government regulation at the national level over closure on a more local level, because "individual choice is most dependent upon local mobility" and we should therefore prefer "local communities ... determined solely by personal preference and market capacity." Id. Yet we observe that in U.S. cities with large immigrant populations, different ethnic groups readily form their own communities without any government regulation. This phenomenon suggests that we would hardly need to restrict local mobility to ensure the survival of neighborhoods with distinctive cultures. These communities, however, would not be permanent enough to satisfy Walzer: "Neighborhoods might maintain some cohesive culture for a generation or two on a voluntary basis, but people would move in, people would move out; soon the cohesion would be gone." Id. For Walzer, it seems important that these communities not only remain distinct but also persist indefinitely in the same geographic space.

218 Dworkin's objection, for example, may apply to such cultural preferences. His concept of external preferences is broader than the concept of racist preferences. For example, Dworkin includes "moralistic" preferences as external preferences. If some "think that the theater is immoral and ought to be repressed," Dworkin argues that these preferences should also be excluded from consideration in the formulation of public policy: "If the moralistic preferences are counted, ... actors and audiences will suffer because their preferences are held in lower respect by citizens whose personal preferences are not themselves engaged." DWORKIN, supra note 199, at 235 . Similarly, a preference that "homosexuality should be repressed," even if based on sincere moral beliefs rather than prejudice, would also be an external preference that Dworkin would exclude from consideration. Id. at 236. John Harsanyi makes a similar distinction between "personal preferences" and "moral preferences." John C. Harsanyi, Morality and the Theory of Rational Behaviour, in UTILTARIANISM AND BEYOND 39, 47 (Amartya Sen \& Bernard Williams eds., 1982).

Dworkin also considers "political theories that are themselves contrary to utilitarianism" to be external preferences that a utilitarian should exclude: "If utilitarianism counts these political preferences at face value, then it will be, from the standpoint of 
the United States, with a commitment to equal treatment and respect for different individual conceptions of the good, it may be difficult to justify immigration restrictions on the basis of preferences of some citizens for a particular national culture while still remaining faithful to these liberal principles. ${ }^{219}$ Mark Tushnet takes the United States to be an exemplary liberal state, "constituted by commitments to liberal toleration." serve the existing distribution of values in a society, in a way inconsistent with a liberal state's commitment to the possibility of revising its own values as the values of its members change." ${ }^{221}$ Tushnet concludes that " $[\mathrm{t}]$ here is therefore no principled reason to object to the transformation of the polity that will occur when those with different values enter." ${ }^{, 222}$ As the U.S. Supreme Court once stated, "[i]f there is any fixed star in our constitutional constellation, it is that no official,

personal preferences, self-defeating, because the [outcome] will then not be, from that standpoint, utilitarian at all." DWORKIN, supra note 199, at 235. Bernard Williams also argues that a utilitarian should not count prejudices or moral preferences, for they may be irrational from a utilitarian point of view. See Bernard Williams, A Critique of Utilitarianism, in JJ.J.C. SMART \& BERNARD WILLIAMS, UTILITARIANISM: FOR \& AGAINST 75, $104-06$ (1973).

${ }^{219}$ As Michael Sandel observes, "[ $\left.t\right]$ he public philosophy of contemporary American politics is a version of this liberal tradition of thought," which holds that "government should be neutral toward the moral and religious views its citizens espouse" and "should not affirm in law any particular vision of the good life." MICHAELJ. SANDEL, DEMOCRACY's DISCONIENT: AMERICA IN SEARCH OF A PUBLIC PHILOSOPHY 4-5 (1996).

${ }^{220}$ Tushnet, supra note 207 , at 154 .

221 Id. at 153; see id. at 154 ("[V] alue-based exclusions assume that the values constituting a polity are fixed, yet that assumption seems unfounded and arguably inconsistent with liberalism's basic commitments."); see also Jost Delbrück, Global MigrationImmigration-Multiethnicity: Challenges to the Concept of the Nation-State, 2 IND. J. GLOBAL LEGAL STUD. 45, 62 (1994) (setting forth the ideal of the "Open Republic," which would accept "citizens of different ethnic, religious or cultural backgrounds" and would feature "tolerance, respect for others being different, and the readiness of each person to let herself or himself be enriched in her or his own personal development by the social diversity around her or him").

${ }^{222}$ Tushnet, supra note 207, at 155 (footnote omitted). Tushnet adds, however, "the qualification that the community must satisfy minimum norms of political justice-the 'no tyranny' requirement." Id. at 157 n.25. Similarly, Bruce Ackerman concludes that the only legitimate reason for a liberal state to restrict immigration is to protect the liberal state itself. See BRUCE A. ACKERMAN, Social JUSTICE IN. THE LIBERAL STATE 95 (1980) ("The only reason for restricting immigration is to protect the ongoing process of liberal conversation itself. Can our present immigration practices be rationalized on this ground?"). 
high or petty, can prescribe what shall be orthodox in politics, nationalism, religion, or other matters of opinion." 223

Moreover, preferences for the ethnic status quo would only imply an upward adjustment in the optimal tariff, ${ }^{224}$ unless we are prepared to discriminate explicitly on the basis of ethnicity. ${ }^{25}$ We could, for example, return to the infamous "national origins" quota system that the United States used to regulate immigration from 1921 to 1965-a quota system heavily biased in favor of immigration from Northern and Western Europe and against immigration from elsewhere. In fact, a Senate report defended this system in 1950 as "a rational and logical method of... restricting immigration in such a manner as to best preserve the sociological and cultural balance in the population of the United States." ${ }^{226}$ It was our recognition of the illegitimacy of our preferences for particular ethnic groups, however, that motivated Congress in 1965 to eliminate this quota system. ${ }^{227}$ If cultural concerns could not justify policies so closely tailored to maintaining the ethnic status quo, then how can they be any more acceptable as a reason to restrict immigration generally? ? $^{228}$

Finally, any legitimate preferences for the ethnic status quo would have to be weighed against the countervailing preferences of those who favor a more diverse, multicultural society. ${ }^{229}$ From this perspective, it is unclear whether a utilitarian calculus would suggest that

${ }^{223}$ West Va. State Bd. of Educ. v. Barnette, 319 U.S. 624, 642 (1943) (striking down a compulsory flag salute as unconstitutional).

${ }^{224}$ The optimal tariff would be raised to reflect the "external cost" imposed on natives by the alien's race, ethnicity, or culture. The resulting quantity of immigration would be an optimum that takes this "negative externality" into account.

${ }^{225}$ Peter Brimelow, for example, suggests that U.S. immigration policy discriminate explicitly on the basis of national origin, asking: "Isn't honesty the best policy?" BRIMELOW, supra note 196, at 261. As a presidential candidate in 1992, Patrick Buchanan cited cultural concerns as a reason to distinguish between immigrants based on national origin: "[I]f we had to take a million immigrants in say, Zulus, next year, or Englishmen, and put them up in Virginia, what group would be easier to assimilate and would cause less problems for the people of Virginia?" Douglas Jehl, Buchanan Raises Specter of Intolerance, Critics Say, L.A. TIMES, Mar. 17, 1992, at Al.

${ }^{226}$ S. REP. NO. 81-1515, at 455 (1950).

${ }^{227}$ See U.S. COMM'N ON CIVIL RIGHTS, THE TARNISHED GOLDEN DOOR: CIVIL RIGHTS ISSUES IN IMMIGRATION 11 (1980) ("The national origins immigration quota system generated opposition from the time of its inception, condemned for its attempts to maintain the existing racial composition of the United States.").

${ }^{228}$ See supra note 204.

${ }^{220}$ See, e.g., Bill Ong Hing, Bejond the Rhetoric of Assimilation and Cultural Pluralism: Addressing the Tension of Separatism and Conflict in an Immigration-Driven Multiracial Society, 81 CAL. L. REV. 863, 869-70 (1993) (articulating a model of cultural pluralism as an ideal for the United States). 
immigration on balance produces a public good or a public bad. ${ }^{250}$ As Joseph Carens concludes in his defense of open borders:

Open immigration would change the character of the community but it would not leave the community without any character. It might destroy old ways of life, highly valued by some, but it would make possible new ways of life, highly valued by others. The whites in Forsythe County who want to keep out blacks are trying to preserve a way of life that is valuable to them.... [C]onstraining the kinds of choices that people and communities may make is what principles of justice are for... To commit ourselves to open borders would not be to abandon the idea of communal character but to reaffirm it. It would be an affirmation of the liberal character of the community and of its commitment to principles of justice.

Especially given the ugly role that racism and xenophobia have played in the formulation of U.S. immigration policies in the past, we should be reluctant to endorse preferences for the ethnic or cultural status quo as a justification for our current restrictions. ${ }^{232}$

The nativist may respond that our moral intuitions regarding racial segregation are misleading when applied to the immigration context. Perhaps some legitimate interests do support racial segregation in theory, but we reject racial discrimination in the domestic context because the costs to the victims of discrimination outweigh those benefits, not because the benefits are wholly illegitimate. The immigration context is different because the primary victim of immigration restrictions (the alien) is not entitled to equal concern in the eyes of the nativist. The nativist discounts the interests of the immi-

${ }^{250}$ We cannot rely on the political process to reveal which set of legitimate preferences dominates, because people may express illegitimate preferences as well as legitimate preferences for the ethnic status quo when they support immigration restrictions.

${ }^{231}$ Carens, supra note 26, at 271.

${ }^{232}$ See Tushnet, supra note 207, at 150 ("A more realistic view, informed by the history of immigration policy, would be more skeptical about such policy. Rather than admirable efforts to ... preserve morally valuable communities, present immigration practices seem racist and ethnocentric."). Michael Trebilcock criticizes Walzer's communitarian justification for immigration restrictions:

I see no role at all for variables relating to applicants' ethnic or cultural backgrounds, despite efforts by Walzer and others to justify exclusions on grounds of preserving cultural homogeneity-"they are not like us." This form of communitarianism has been invoked in the past to justify some of the most egregious forms of racial and religious discrimination in the history of Canada and the United States.

Trebilcock, supra note 186, at 240 (footnote omitted); see U.S. COMM'N ON CIVL RIGHTS, supra note 227, at 7-12 (reviewing the history of discrimination in U.S. immigration policies). 
grant and can thereby distinguish immigration restrictions from discrimination among natives.

The problem with this logic, however, is that it would justify pervasive discrimination against immigrants by local governments, private employers, and other parties in the domestic context. Our moral intuitions regarding such discrimination suggest that we do not regard preferences for ethnic or cultural purity to be legitimate justifications for discrimination against immigrants, either because such preferences are illegitimate or because the welfare of immigrants outweighs these interests. That is, our moral intuitions regarding discrimination in the domestic context also raise the question: is it appropriate either to ignore or to discount the welfare of aliens? Thus, the analogy between immigration restrictions and racial segregation challenges the morality of the nativist premise itself. ${ }^{233}$ In the remainder of this Article, I relax the nativist assumption and consider the welfare of aliens. The objections to racist, ethnocentric, and xenophobic reasons to restrict immigration apply with still greater force once we include the welfare of aliens among our objectives.

\section{CONCERN FOR THE WELFARE OF IMMIGRANTS}

The policies described above, which include discriminatory and regressive taxes imposed on our poorest immigrants, may seem offensive because we do not truly believe that the welfare of immigrants should count for nothing. The preceding analysis assumed a nativist measure of social welfare: our objectives included only the welfare of natives. This assumption may be unjustifiably indifferent to the welfare of immigrants. ${ }^{234}$ We can instead take a broader view of "national economic welfare" that includes the welfare of immigrants. ${ }^{235}$ If our

${ }^{299}$ Carens concedes that "the requirement of equal treatment applies fully only to those who are already members of the community," but only "as a description of practice." Carens, supra note 26, at 268. For Carens, "the question is why it should be so." Id.

${ }^{234}$ See, e.g., Gillian K. Hadfield, Just Borders: Normative Economics and Immigration Law, in JUSTICE IN IMMIGRATION, supra note 7, at 201, 204 ("A social welfare function defined over original residents presumes rather than demonstrates that original residents are the people among whom resources should be distributed.... [T] his is obviously inadequate as a contribution to the normative debate about ethically defensible policy with respect to immigration.").

${ }^{235}$ See Bhagwati \& Srinivasan, supra note 27 , at 212 ("[O]nce labour crosses national borders, we have to worry about which country's welfare it ought to be included in.... [W] need ... to consider the possibility that it may be regarded, after immigration, to be part of one's own welfare."). Bhagwati and Srinivasan analyze optimal policies from the perspective of national economic welfare, first "where welfare of immi- 
objectives also include the welfare of immigrants, however, then the optimal policies are still likely to entail more immigration than our laws currently allow. Indeed, if we care enough about the welfare of immigrants, then we would also impose lower taxes on poor immigrants and offer them greater access to public entitlements than would otherwise be optimal.

\section{A. The Optimal Tariff}

To the extent that immigrants are objects of our concern, their needs may militate in favor of lower tariffs. The force of "market power" considerations diminishes insofar as we consider the tax burden on immigrants to be a social cost. Concern for the welfare of immigrants militates against taxes designed to drive down their aftertax wages. Therefore, to the extent that the supply of immigrant labor is inelastic, so that the incidence of the tariff falls on immigrants, concern for immigrant welfare will militate in favor of lower tariffs. We would choose to extract less tax revenue from each immigrant than we would otherwise, in order to comply with moral principles that prevent us from ignoring the welfare of others.

On the other hand, it is also possible that concern for immigrants could militate in favor of higher tariffs. If we include the welfare of immigrants in our measure of social welfare, then we would modify our measure of external congestion costs of immigration to include the costs imposed on other immigrants as well as those imposed on natives. To the extent that the welfare of immigrants is a matter of concern, so are the congestion costs that they bear when we admit additional immigrants. To the extent that immigrants make up a significant portion of the total resident population, this concern will imply a larger positive Pigouvian component of the optimal tariff.

The net effect of these two countervailing effects will in general be ambiguous. ${ }^{236}$ If concern for the welfare of immigrants cuts on

grant labour is considered part of only foreign welfare," then discussing "the complexities introduced in the case when this cannot be assumed." Id. at 212-13.

${ }^{236}$ If congestion costs loom large relative to "market power" considerations as components of the optimal tariff, then it is possible for that tariff to rise as we attach greater weight to the welfare of immigrants. If the supply of immigrant labor were perfectly elastic, for example, then immigrants would not bear the burden of tariffs. Only the effect on congestion costs would exist, and concern for immigrants would militate unambiguously in favor of higher tariffs.

For relatively affluent immigrants, both effects are likely to be relatively small. Congestion costs are likely to be a relatively minor consideration in the determination of the optimal tariff. Whereas the other components of the optimal tariff would tend 
balance in favor of lower tariffs on immigrants, then it becomes more likely that negative tariffs are optimal for skilled immigrants. These negative tariffs would increase in absolute value, and they would probably apply to a larger and less affluent class of immigrants. For unskilled workers, we may reduce tariffs and extend public entitlements beyond what the collective self-interest of natives would dictate. Positive tariffs would decrease and would apply to a smaller and poorer class of immigrants. As the optimal tariff falls below the level that maximizes the economic welfare of natives, we transfer wealth from natives to immigrants. To some extent, however, we would be willing to pay this price to satisfy our altruistic preferences for the welfare of immigrants or to comply with principles of justice.

If tariffs fall, then immigration would expand. As long as taxes remain above Pigouvian levels, however, the marginal immigrant would still make a net positive contribution to the public sector. Therefore, expansion in immigration would be in the interests of those already in the host country-both natives and inframarginal immigrants-as well as in the interest of the marginal immigrant. Because taxes above Pigouvian levels distort immigration below the level that would maximize the welfare of those already in the host country, this expansion in immigration counts as a benefit of tariff reduction rather than a cost.

On the other hand, if concern for the welfare of immigrants cuts in favor of higher rather than lower tariffs, then immigration would fall below the level that would be optimal for natives. Natives would gain more revenue from those who still choose to immigrate, but higher tariffs would deter valuable immigration that would confer still greater benefits on natives. We sacrifice these benefits in order to spare prior immigrants the congestion costs that more immigrants would impose on them.

In either case, if our social welfare criteria include considerations of distributive justice as well as efficiency, it may become optimal to set taxes below Pigouvian levels for some immigrants. If we extend considerations of vertical equity to immigrants as well as natives, and we give sufficient weight to the welfare of immigrants, then it may be optimal to set taxes at such levels for the poorest immigrants, for

to increase in proportion with income, the congestion costs imposed by an immigrant would probably fall as a proportion of income. On the other hand, "market power" considerations are also likely to be unimportant for affluent immigrants. Given that even natives in such high income classes are subject to high taxes, there will be little reason to add an additional tariff on similar immigrants. 
whom these taxes would be most burdensome. ${ }^{237}$ Taxes this low, however, would imply that the marginal immigrant would impose a net cost on the public sector. This migration would be in the self-interest of the marginal immigrant, but not in the self-interest of those already resident in the host country. These more generous policies would induce immigration above levels that would maximize the economic wealth of host-country residents. Indeed, immigration at this level would be inefficient in that it would reduce the wealth of current residents by more than it would increase the wealth of the additional immigrants. Immigration at this level would entail an efficiency cost rather than confer a net benefit.

To some degree, however, principles of distributive justice would require us to bear these costs, or we may be willing to bear them out of an altruistic desire to improve the welfare of poor immigrants. Even with respect to natives, after all, redistributive policies have efficiency costs because in general they distort incentives to work and save. Why should some inefficient migration be any less tolerable than these other costs? ${ }^{238}$

Nevertheless, the problem of excess immigration of poor aliens would be a reason to make tax and transfer policies less generous than would otherwise be optimal. For example, in the limit, we may extend to aliens the same concern that we extend to natives. Equal concern, however, need not imply equal tax treatment. Even if we give equal weight to the welfare of aliens and of natives, optimal tax considerations may call for different tax rates. If the supply of immigrant labor is more elastic than the supply of similarly skilled native labor, then a given tax or subsidy would cause a greater distortion in the supply of immigrant labor than in the supply of native labor. That is, a given tax or subsidy for immigrants would entail greater social

237 Taxes below the Pigouvian level may be optimal even if the optimal tariff rises rather than falls with increasing concern for the welfare of immigrants. Because the Pigouvian component of the optimal tariff rises with increasing concern for the welfare of immigrants, it may rise above the optimal tariff even if the optimal tariff itself also rises. That is, the other components of the optimal tariff will fall, and with suffcient weight for the welfare of immigrants, these other components will become negative for sufficiently poor immigrants.

${ }^{293}$ Arthur Okun describes the tradeoff between equality and efficiency with the metaphor of a leaky bucket. See ARTHUR M. OKUN, EQUAITY AND EFFICIENCY: THE BIG TRADEOFF 91-106 (1975). Redistribution of wealth from the rich to the poor always occurs with leakage, because it always entails some efficiency costs. A government concerned with both equality and efficiency would choose to transfer wealth only until it becomes too costly to transfer more. Inefficient immigration would be one more example of an efficiency cost of redistributive policies. 
costs than the same policy applied to native workers, because the policy would distort the immigration decision. Therefore, the optimal tax on immigrants would still tend to be smaller than the optimal tax on natives, and the optimal subsidy for poor immigrants would still tend to be smaller than the optimal subsidy for poor natives.

\section{B. The Optimal Quota}

The foregoing discussion, however, excluded quantitative restrictions from consideration. Once our objectives include a desire to redistribute wealth to poor immigrants, so that some immigration exceeds the efficient level (which would maximize host-country wealth), then immigration quotas can play a useful role, but only because they permit more generous treatment of immigrants. In particular, immigration ceilings enable the host country to offer poor immigrants more generous fiscal policies without inducing excessive levels of immigration in these income classes. ${ }^{239}$ Once a dollar in the hands of a poor immigrant produces more social welfare than it would in the public sector, then we may prefer quotas over tariffs as a means of regulating immigration levels, because quantitative restrictions leave quota rents in the hands of immigrants rather than extracting them as tax revenue.

If we extend equal concern to immigrants and natives, for example, then the optimal policy would generally apply nondiscriminatory fiscal policies to immigrants but impose quantitative restrictions on some immigration. If we do not wish to discriminate against these immigrants, then we can also offer them access to citizenship consistent with our preferences regarding redistributive policies. As long as the policies we wish to apply to immigrants are sufficiently similar to those we wish to apply to natives, we may also allow aliens to immigrate with a legal status that implies access to citizenship within a short period of time. Quotas, however, would be justified only for those classes of immigrants that impose a net burden on the public sector.

Given a measure of social welfare that includes the welfare of immigrants, what would be the optimal immigration quota? One candidate might be the quantity of immigration that would emerge under a

${ }^{239}$ The host country would also like to impose floors on the immigration of affluent immigrants, because they would permit the government to impose higher taxes without distorting such immigration below optimal levels. It is not possible, however, to force people to immigrate. 
Pigouvian tax. That level of immigration would be efficient: that is, it would equate the marginal benefits and marginal costs of immigration and thereby maximize the wealth of host-country residents. It would exclude all immigration that would be inefficient from the perspective of national economic welfare.

This immigration quota would be quite liberal: it would be high enough to exhaust the gains from trade (net of external costs). We would permit so much immigration that foreign wages would rise to the point where no more immigrants would be willing to immigrate if subject to a Pigouvian tax. Given the large international differences in wages created by current immigration policies, the efficient level of immigration for the United States is likely to be higher than existing immigration quotas permit.

On the other hand, if fiscal policies are in fact more generous than a Pigouvian tax would be, then the marginal immigrant at the Pigouvian level of immigration would impose a net burden on the public sector without paying offsetting taxes and would have a negative effect on the wealth of other host-country residents. Given this effect on incumbent residents, one might think that a more restrictive quota would be appropriate. Such a conclusion, however, would be perverse, because the only justification for immigration quotas in the first place is to allow for policies more generous towards poor immigrants than a Pigouvian tax. If concern for the welfare of these immigrants motivates these generous policies, then it would be perverse to exclude the very immigrants whose welfare we would seek to improve through such policies.

It would be incoherent public policy to turn away the marginal immigrant, citing a negative effect on the welfare of current residents, given that we always have the option of permitting immigration subject to a Pigouvian tax. This option would improve the welfare of the marginal immigrant and the welfare of current residents. It would also transform the marginal immigrant into a resident, however, and if our social welfare criterion includes the welfare of all residents, then the same distributive concerns that justified generous policies for other residents would seemingly apply to the marginal immigrant as well. In short, no measure of social welfare that counts an individual's welfare if and only if the individual is a resident can provide a coherent criterion for the optimal immigration policy, because that policy determines the identity of the population of residents.

If we exclude the potential immigrant because we anticipate the transfers that we would make to that immigrant after admission, then 
we produce an anomaly: the potential immigrant would be better off if we never cared about that immigrant's welfare. To avoid this anomaly, we must consider the welfare of an alien to be morally relevant not only after admitting the alien but also in deciding whether to admit that alien in the first place. Thus, the only coherent welfare criterion would consider the welfare of the potential immigrant in setting the immigration quota, not just the welfare of current residents (that is, natives and inframarginal immigrants). No other criterion would be consistent with the underlying rationale for immigration quotas. If we consider the welfare of the potential immigrant, however, then the optimal quota will be even more liberal than the quota equivalent to a Pigouvian tax.

Although the Pigouvian immigration level would be efficient from the perspective of national economic welfare, this perspective neglects considerations of distributive justice. To maximize social welfare, defined to include distributive concerns and the welfare of the potential immigrant as well as the welfare of current residents, we would choose higher levels of immigration. If we include the welfare of the potential immigrant as a component of social welfare, then we would increase the quota until the efficiency costs are too large relative to the increase in the marginal immigrant's welfare. At the Pigouvian quantity of immigration, the marginal immigrant would enjoy a large gain from immigrating, given fiscal policies more generous than a Pigouvian tax. The marginal immigrant's gain would also represent a large (first-order) gain in social welfare. One additional immigrant would distort immigration only a small amount above efficient levels, and so would impose only a small (second-order) social welfare loss. As we allow more immigration, wages abroad would rise and the gain to the marginal immigrant from migration would therefore fall. Meanwhile, the efficiency costs would grow larger at higher levels of immigration. We would raise the immigration quota until the gain to the marginal immigrant no longer justified the efficiency cost. $^{240}$ That is, the optimal quota would be liberal enough to ensure that the aliens excluded would suffer relatively little economic harm from exclusion. This quota would probably entail significantly more immigration than our laws currently allow, given that our welfare cri-

${ }^{240}$ The optimal immigration quota, however, would still bind. The equilibrium level of immigration in the absence of quantitative restrictions would be excessive. The gain to the last immigrant would be small (second-order), but the corresponding efficiency cost would be large (first-order). Therefore, it would be optimal to restrict immigration below the equilibrium level. 
terion would include special concern for increasing the wealth of poor immigrants as well as poor natives.

\section{The Optimal Allocation of Visas Subject to Quotas}

Any binding immigration quota also raises the issue of allocating the immigration visas. Among the many who would be willing to immigrate on such favorable terms, who should receive these scarce visas? Given the excess demand for these visas, what would be the optimal criteria for deciding which aliens to admit?

First, the classes of immigrants subject to quantitative restriction would include all immigrants poor enough to impose a net burden on the public sector. To the extent that this category includes different classes of immigrant labor, including some more skilled than others, then the optimal mix of immigrants would generally include some immigrants from each class. That is, the optimal quota for each class would be determined by the type of social-welfare cost-benefit analysis set forth above, including distributive concerns that give special weight to increases in wealth for the poorest immigrants. If these various quotas are set optimally, then there is no reason to allocate all these quota-restricted visas to one particular class of immigrant labor instead. In particular, there is no presumption that all visas should necessarily go to the immigrants with the highest skill levels. ${ }^{241}$

Second, within each class of labor, one would expect each potential immigrant to have roughly the same economic impact on incumbent residents. Yet there would still be excess demand for visas and thus a need to distinguish among potential immigrants within each class. From the perspective of social welfare, it would be optimal to allocate these visas to those immigrants who would gain the most from immigration. In this regard, refugees or relatives of current

24! Contrast this policy with that suggested by Borjas, supra note 35 , at 12-19. Borjas assumes implicitly that an overall quota on total immigration is fixed, applies to all classes of labor, and binds regardless of how these visas are allocated among classes. Borjas suggests that to maximize the welfare of natives, the United States should allocate the visas subject to this quota to skilled immigrants rather than unskilled immigrants. The analysis in Part II of this paper considers the welfare of immigrants as well as the welfare of natives and assumes that we can set quotas at optimal levels. The optimal policy would not impose any quotas on the most skilled immigrants. It would impose quotas on the least skilled immigrants, but these quotas would be generous enough to exhaust all gains from trade (net of external costs) and would also reflect considerations of distributive justice. Thus, optimal quotas would in general be liberal enough to include a variety of skill levels within the classes of labor that are subject to immigration quotas. 
residents have special claims to immigration based on the special benefits their immigration produces. ${ }^{242}$ The refugee escapes persecution and thus enjoys benefits beyond those produced by the immigration of other aliens with similar skills. Family-based immigration produces the psychic benefits associated with the reunification of families, enjoyed by both the immigrant and the resident sponsor. Thus, we may offer immigration visas to relatives of immigrants not only to further the economic interests of natives but also for reasons other than economic self-interest. ${ }^{243}$ Concern for the welfare of immigrants militates in favor of giving priority to refugees and familybased immigrants in the allocation of visas subject to quotas.

\section{GLOBAL ECONOMIC WELFARE}

The preceding analysis considered the welfare of each potential immigrant in deciding whether to admit that immigrant, but did not consider the effects of admitting that immigrant on those aliens left behind in foreign countries. If we are concerned about the welfare of not only natives but also aliens, including potential immigrants, however, then why limit this concern to immigrants? What about the welfare effects of each admission on foreign public coffers or on participants in labor markets abroad?

We might take a more cosmopolitan view of the appropriate welfare objective. ${ }^{244}$ Consider the theory of justice developed by John Rawls, who asks what principles people would choose behind a "veil of ignorance. ${ }^{245}$ In this "original position," people know nothing about

${ }^{242}$ Sykes describes these benefits from the perspective of national welfare, even excluding the gains enjoyed by the immigrant: "Family reunification affords substantial psychic benefits to existing residents, and entry for refugees allows existing residents the satisfaction of an altruistic policy.... [T] he immigration of family members and refugees confers more benefit upon other residents than the immigration of individuals in neither category, other things being equal." Sykes, supra note 7, at 183.

${ }^{213}$ As discussed above, we may provide immigrants with the right to sponsor relatives for immigration as a policy to encourage the immigration of skilled aliens. These aliens may be reluctant to migrate without these relatives, or they may simply consider the right to sponsor a relative to be an attractive benefit. The immigration of these skilled immigrants may be valuable enough to warrant immigration visas for their relatives.

${ }^{211}$ See, e.g., Hadfield, supra note 234, at 205 ("If economists are to participate in the normative debate over immigration ... there can be no starting point other than a global social welfare function. Only a welfare function in which everyone at least potentially counts avoids the question begging raised by a national social welfare function.").

${ }^{245}$ See JOHN RAWLS, A THEORY OFJUSTICE $136-42$ (1971). 
their own personal circumstances or traits. "They do not know how the various alternatives will affect their own particular case and they are obliged to evaluate principles solely on the basis of general considerations." ated and treated equally as moral persons." ${ }^{247}$ Using Rawls's theory, Joseph Carens addresses the issue of immigration restrictions as a question of international justice. ${ }^{248}$ In seeking a justification for the use of force to exclude aliens, "we don't want to be biased by selfinterested or partisan considerations" and instead "can take it as a basic presupposition that we should treat all human beings, not just members of our own society, as free and equal moral persons." "249 "We should therefore take a global, not a national, view of the original position.",250

If we begin with equal concern and respect for all persons, then immigration barriers are morally suspect and demand justification. All immigration restrictions discriminate against individuals based on their alienage, which in turn derives from immutable characteristics such as birthplace (that is, national origin) and other circumstances of birth such as parentage. ${ }^{251}$ National origin would appear to be a

${ }^{246} I d$. at 136-37; see id. at 141 ("If a knowledge of particulars is allowed, then the outcome is biased by arbitrary contingencies.").

${ }^{247} I d$. at 141.

${ }^{248}$ Carens, supra note 26 , at 255.

${ }^{249} \mathrm{Id}$. at 256. Carens identifies this premise as a basic feature of all liberal political theories. See id. at 265 (claiming that "our social institutions and public policies must respect all human beings as moral persons," which "entails recognition ... of the freedom and equality of every human being"); see also id. at 269 ("No moral argument will seem acceptable... if it directly challenges the assumption of the equal moral worth of all individuals.").

${ }^{250} I d$. at 256.

${ }^{25}$ See Roger Nett, The Civil Right We Are Not Ready For: The Right of Free Movement of People on the Face of the Earth, 81 ETHICs 212, 224 (1971) ("May we expect the lesson which the Negro has taught his fellow Americans about denial of fair opportunities to be repeated on a broader scale, with the underprivileged of the earth demanding 'desegregation' of nation states?"). The Supreme Court has recognized that discrimination against aliens may reflect popular prejudice against them or their lack of political power: "[C]lassifications based on alienage, like those based on ... race, are inherently suspect and subject to close judicial scrutiny. Aliens as a class are a prime example of a 'discrete and insular' minority for whom such heightened judicial solicitude is appropriate." Graham v. Richardson, 403 U.S. 365, 372 (1971) (quoting United States v. Carolene Prods. Co., 304 U.S. 144, 153 n.4 (1938)) (footnotes \& citation omitted). Rosberg suggests that the same reasoning applied to discrimination by the states in Graham $v$. Richardson should also apply to the federal government:

Aliens stand in the same position with respect to the federal government as they do with respect to the states.... They are as effectively excluded from the political process at the national level [as at the state level].... And aliens 
trait that Rawls would deem "arbitrary from a moral point of view." 252 Carens concludes that we cannot justify restrictions "on the grounds that those born in a given territory or born of parents who were citizens were more entitled to the benefits of citizenship than those born elsewhere or born of alien parents." ${ }^{, 233}$ Nor can we justify restrictions "on the grounds that immigration would reduce the economic wellbeing of current citizens." ${ }^{254}$ Similarly, in a utilitarian calculation of global social welfare, "current citizens would enjoy no privileged position." Carens concludes that "we have an obligation to open our borders much more fully than we do now."

have suffered as long a history of purposeful unequal treatment at the hands of the federal government as they have at the hands of the states.

Rosberg, supra note 113, at 314 (footnote omitted); see id. at 294 ("[I]f alienage is a suspect classification when made the basis of state legislation, should it not remain suspect when it is used by the federal government?"). Nevertheless, the Court has refused to apply close scrutiny to discrimination by the federal government against aliens, especially in the context of immigration policy. See Mathews v. Diaz, 426 U.S. 67, 81-82 (1976) (justifying "a narrow standard of review of decisions made by the Congress... in the area of immigration and naturalization" on the ground that "these matters may implicate our relations with foreign powers"); Calavita, supra note 15, at 148 ("It seems then that inalienable human rights, such as the right of free movement, do not apply to aliens.").

${ }^{252}$ RAWLS, supra note 245 , at 72.

${ }^{25 s}$ Carens, supra note 26, at 261. Carens adds that "restrictions on immigration for the sake of preserving a distinctive culture would be ruled out," because "in the original position ... no one would be willing to risk the possibility of being required to forego some important right or freedom for the sake of an ideal that might prove irrelevant to one's own concerns." Id. at 262. Even if the desire to preserve national culture were free of prejudice, Carens argues that "the effect of immigration on the particular culture and history of the society would not be a relevant moral consideration, so long as there was no threat to basic liberal democratic values." Id. He bases this conclusion on his reading of RAWLS, supra note 245, at 325-32.

${ }^{254}$ Carens, supra note 26, at 262 . Rawls advances two principles of justice. See RAWLS, supra note 245 , at $60-65$. The first would ensure equal liberty for all. The second, the "difference principle," would permit inequalities as long as they "work as part of a scheme which improves the expectations of the least advantaged members of society." Id. at 75. Rawls gives priority to the first principle over the second. See id. at 61. Carens argues that both the priority of liberty and the difference principle militate against immigration restrictions. See Carens, supra note 26, at 262.

${ }^{235}$ Carens, supra note 26 , at 263 . "[T] he utilitarian commitment to moral equality is reflected in the assumption that everyone is to count for one and no one for more than one when utility is calculated." Id. Even if we include the preferences of racists and xenophobes in the calculus, once we also include the welfare of aliens, "the final outcome is still likely to favor much more open immigration than is common today." Id. at 264.

${ }^{256}$ Id. at 270. Carens condemns immigration restrictions: "Like feudal barriers to mobility, they protect unjust privilege." Id. Similarly, Bruce Ackerman concludes that immigration barriers are inconsistent with liberal principles. See ACKERMAN, supra note 
My analysis now turns to the question posed by theorists like Carens: What immigration barriers, if any, can be justified from the perspective of global welfare? This analysis should be relevant even for those who have more provincial views of the appropriate welfare objective of national immigration policies. In particular, the optimal international migration regime from the perspective of global economic efficiency also represents the optimal outcome of international negotiations. That is, it is in theory possible for the nations of the world to negotiate a multilateral agreement, including appropriate side payments, that would move us to that regime and simultaneously make each nation better off than it is under current inefficient policies. $^{257}$ Therefore, I will discuss policies that would require international cooperation as well as those that a country of immigration might undertake unilaterally.

To maximize global economic welfare, we would consider not only the welfare of natives and immigrants but also the welfare of those aliens who remain residents of countries of emigration. The effects on their welfare, like the effects on the welfare of natives, may be divided into those transmitted through the labor market and external effects. First, consider the effects of migration on labor markets and set aside the external effects of immigration.

\section{A. Effects in the Global Labor Market}

In the absence of external effects, free trade in the labor market, like free trade in goods, would maximize global economic welfare. Economic efficiency would call for unrestricted migration, which would allow labor to move freely to the country where it earns the highest return. Market forces would thus direct labor to the market where its marginal product is highest. While natives gain from trade with immigrants in the labor market, the countries of emigration lose their gains from trade when these migrants depart. Workers will mi-

222 , at 93 ("I cannot justify my power to exclude you without destroying my own claim to membership in an ideal liberal state.").

${ }^{257}$ Thus, such an agreement can meet the test suggested by John Scanlan for "[d]oing good for the world at large" consistent with national self-interest:

[D]oing good must be associated with the probability of the people at home doing well-or at least doing better than otherwise would be likely. Coordinated or collective international policies that meet this test are politically defensible ... but multilateral or global policies that fly in the face of important local interests will fail.

Scanlan, supra note 5, at 107 (footnote omitted). 
grate to countries where they can earn a higher real wage, that is, where the gains from trade are greater. Thus, according to standard economic theory, although the country of emigration may lose its gains from trade with migrants, the country of immigration and the migrants would gain more than the country of emigration loses. ${ }^{258}$

Whether imposed on goods or on labor, tariffs designed to exploit market power only improve the welfare of the importing country by extracting wealth from aliens. The benefit derived by the importing country is a pure transfer, but the costs of these tariffs would be a real deadweight loss to the world economy. Such "optimal" tariffs would be beggar-thy-neighbor policies and inconsistent with the maximization of global economic welfare. The optimal immigration tariff for a host country would extract revenues from migrants for the benefit of the host country (and by discouraging migration would incidentally produce benefits for nonmigrants in the source country) but in the process would also introduce costly distortions in migration. These distortions would impose costs on the country of immigration as well as on the migrants, resulting in a net loss for the world economy.

\section{B. External Effects}

What about the external effects of immigration? We have seen how external effects on the residents of the country of immigration can provide some justification for the regulation of immigration from the standpoint of national economic welfare. To the extent these welfare effects also enter into the analysis of global economic welfare, perhaps they can also justify some immigration restrictions from this broader perspective.

${ }^{258}$ See Sykes, supra note 7, at 167 ("Such analysis implies that for a nation interested in maximizing its national advantage, emigration is a source of concern. Immigration, by contrast, is to be welcomed ...." (footnote omitted)). The tendency of migrant workers to send remittances back home to help support friends and family who remain, however, may mitigate if not eliminate the welfare losses for the country of emigration. See WORLD BANK, WORLD DEVELOPMENT REPORT 1995: WORKERS IN AN INIEGRATING WORLD 66 (1995) ("Migration generally leads to important gains for the sending country, primarily through remittances. For some countries, remittances represent a sizable share of GNP-between 10 and 50 percent in Jordan, Lesotho, Yemen, and the West Bank and Gaza."). A study of El Salvador in 1987 estimated that remittances from emigrants were equivalent to at least 8.6 percent of the country's gross domestic product. See Edward Funkhouser, Mass Emigration, Remittances, and Economic Adjustment: The Case of El Salvador in the 1980s, in IMMIGRATION AND THE WORK FORCE, supra note 61, at 135,138 . 
The analysis of national economic welfare did not consider the external effects on the residents of countries of emigration. For example, emigration reduces congestion in those foreign countries. ${ }^{259}$ Emigration of the wealthy deprives these countries of tax revenues, and emigration of the poor may reduce the burden imposed on their treasuries by redistributive programs. Thus, the level of migration that is optimal from the perspective of national economic welfare is unlikely to be the optimal level from the perspective of global economic welfare. In particular, globally optimal migration is likely to imply higher levels of migration for the poor (and lower levels of migration for the wealthy) than the levels that would maximize the economic welfare of the country of immigration.

Thus, immigration policies that respond to these external effects, like the "optimal" tariff, may maximize national economic welfare only at the expense of foreign economic welfare. Pigouvian tariffs that seek to internalize congestion costs, for example, could discourage efficient migration, insofar as countries of emigration also experience congestion costs. Unless such countries of emigration impose Pigouvian taxes on their residents or offer them Pigouvian subsidies to encourage emigration, Pigouvian tariffs on immigration would lead to excessive global congestion. If fiscal policies in countries of emigration do not force residents to internalize congestion costs, then the appropriate Pigouvian tariff for the country of immigration would include only the difference between the marginal congestion costs in the host country and the corresponding cost in the source country. Pigouvian tariffs any higher would be beggar-thy-neighbor policies designed to shift congestion to other countries. Similarly, policies to discourage unskilled immigration or to encourage skilled immigration may benefit the public treasury in a country of immigration only at the expense of the public treasury of the country of emigration.

\section{Optimal Fiscal Policies}

So what fiscal policies would maximize global economic welfare? Suppose appropriate Pigouvian taxes internalize all congestion costs. Some migration may be induced or inhibited by variations in other taxes or entitlement programs across countries. Migration induced

${ }^{250}$ Thus, the increase in congestion in countries of immigration and the decrease in congestion in countries of emigration would tend to offset the welfare effects of migration in the labor market. 
by public entitlement programs would be inefficient from an economic perspective because it would not produce net economic gains for the world as a whole. ${ }^{260}$ The most direct response to this problem would be to harmonize redistributive policies among different countries. Harmonization, however, would require international cooperation and would significantly impinge on national sovereignty. Different countries hold different views on how much redistribution is worthwhile. Their different policies reflect different degrees of aversion to inequality.

Another response would be for each country to discriminate between natives and immigrants, and indeed, between immigrants based on their country of origin. To eliminate all distortions in migration decisions caused by fiscal policies, each country of immigration could present each class of migrants with the taxes and entitlement programs that they faced in their home country. ${ }^{261}$ These programs need not discriminate against an immigrant. These policies may be more generous than the policies offered natives (to avoid discouraging efficient migration) or less generous (to avoid encouraging inefficient migration).

This system would allow each country to pursue its own redistributive policies with respect to its own natives without distorting migration decisions. While migration in such a regime would always be efficient, it could also transfer fiscal burdens and benefits between countries. A country that attracted the affluent, for example, would gain. To avoid these effects, one could imagine a regime in which each country of origin continued to tax its natives abroad or provide transfers to them. ${ }^{262}$ This system would require the cooperation of the country of origin and the host country, but would not require their agreement regarding appropriate redistributive policies. In effect, each country of origin could compensate host countries for burdens that migrants imposed on them, and host countries could compensate countries of origin for benefits derived from migrants.

${ }^{260}$ See Sykes, supra note 7, at 193 ("By far the most convincing argument against free immigration from the global efficiency perspective relates to cross-national variation in entitlement programs.").

${ }^{261}$ See John Douglas Wilson, Optimal Income Taxation and Migration: A World Welfare Point of View, in INCOME TAXATION AND INTERNATIONAL MOBILTY 201, 208-09 (Jagdish N. Bhagwati \& John Douglas Wilson eds., 1989).

${ }^{262}$ At present only the United States and the Philippines attempt to tax their citizens abroad. See Richard D. Pomp, The Experience of the Philippines in Taxing Its Nonresident Citizens, in INCOME TAXATION AND INIERNATIONAL MOBILITY, supra note 261, at 43, 43. 
Even in the absence of any international cooperation, the United States could unilaterally, in the name of global economic efficiency, restrict immigrant access to public entitlements to what the immigrant could have received in the immigrant's home country. ${ }^{263}$ Note that this policy would probably be more generous than the policy dictated by the economic welfare of natives alone. ${ }^{264}$ Furthermore, if our measure of social welfare includes distributive concerns, then still more generous transfer policies may be appropriate. If we believe in more redistribution than some countries of emigration, and we apply our own degree of inequality aversion to our measure of global social welfare, then it would be optimal to engage in some more redistribution and to tolerate some inefficient migration. ${ }^{265}$

In theory, it would be better to address the issue of global inequality through transfers that did not require the foreign recipients to migrate. Under the ideal regime, we could provide immigrants with equal access to our redistributive programs and allow free movement of labor while the appropriate transfers to aliens abroad would ensure that they did not have excessive incentives to immigrate. In this sense, generous foreign aid may be more efficient than reliance on domestic programs alone, because it could redistribute wealth to ali-

${ }^{269}$ California and other states have recently moved toward such policies with respect to welfare benefits for those who have resided in state for less than a year. California's new policy will limit new California residents to the welfare benefits that they received in their prior state of residence; only those coming from states providing more generous benefits than California will get benefits at the California rate. Under this policy, someone who moves from Mississippi to Los Angeles will receive $\$ 120$ per month in welfare benefits rather than the $\$ 565$ per month paid to California residents in urban areas. See Virginia Ellis, Lower Welfare for Newcomers Begins Tuesday, L.A. TIMES, Mar. 26, 1997, at A3.

${ }^{264}$ The United States might also, in the name of global economic efficiency, offer more generous public entitlements to an immigrant than those offered to natives, or impose either higher or lower taxes on an immigrant than on natives, so as to match the policies the immigrant would have faced in the immigrant's home country. These discriminatory policies, however, could reduce the economic welfare of natives compared to what they would enjoy under nondiscriminatory fiscal policies.

${ }^{265}$ If we were to pursue our view of global social welfare, rather than national economic welfare, then we would be similarly concerned about wealthy immigrants drawn to our country by our less progressive tax rates. To prevent this inefficient migration, we could impose higher taxes on them if they come from countries with taxes higher than ours. We could implement this policy with or without the cooperation of the countries of emigration. With the cooperation of the country of immigration, for example, a country of emigration could tax emigrants at their higher rates and offer a tax credit for taxes paid to the country of immigration. 
ens without distorting migration decisions. ${ }^{266}$ The United States could transfer wealth either on its own or as part of a multilateral regime designed to redistribute wealth from the rich to the poor worldwide. Henry Shue notes, however, that foreign aid may not be an effective policy instrument with which to redistribute wealth to needy aliens: "With rare exceptions bilateral and multilateral foreign assistance goes directly to, and falls under the control of, the governments of the recipient nation-states. The assistance then may or may not reach the people for whom the donor government or multilateral institution intended it ...."267 Unless our foreign aid program could ensure that each alien received the appropriate transfer, inefficient migration might persist from at least some countries, and this distortion would militate in favor of less generous transfers for immigrants from those countries than those offered natives.

\section{Optimal Quotas}

If equal access to transfers for natives and aliens would cause some inefficient migration, then as before, distributive concerns create a useful role for immigration quotas. If we give equal weight to the welfare of aliens and of natives, then we would offer immigrants the same transfers we offer natives and rely on quantitative restrictions to prevent excessive migration. The national policies that would maximize global social welfare from this perspective would resemble those that would maximize the welfare of natives and immigrants taken together. There are, however, two important differences.

First, the quotas on poor immigrants that would be optimal from this global perspective would apply only to immigrants from countries with less generous redistributive policies, instead of all immigrants with a net negative impact on the public sector. ${ }^{263}$ Only unskilled

${ }^{266}$ See Louis Michael Seidman, Fear and Loathing at the Border, in JUSTICE IN IMMIGRATION, supra note 7, at 136, 141 ('[F]oreign aid redistributes assets with the least deadweight loss.").

${ }_{267}$ SHUE, supra note 31, at 161 ("Ideally, economic assistance to foreign governments would constitute aid to the foreign poor. In fact, sometimes it does and sometimes it does not."); see PETER BOONE, POLITICS AND THE EFFECTIVENESS OF FOREIGN AID 5 (National Bureau of Economic Research Working Paper No. 5308, 1995) (presenting "strong evidence that aid flows primarily benefit a wealthy political elite").

${ }^{26 s}$ If we are reluctant to impose higher taxes on affluent immigrants from countries with more progressive tax systems than ours, so as to prevent excessive migration of this type, we can as an alternative policy impose ceilings on their immigration as well as on that of poor immigrants from countries with less progressive policies than ours. 
immigration from these countries would be inefficient. Other unskilled immigration would be efficient: although it might impose a net burden on the public sector in the host country, it would impose a similar or heavier burden in the source country.

Second, the optimal quotas from the global perspective would be more liberal, because the emigration of the poor confers external benefits on the public sector in foreign countries. Taking these benefits into account implies that both the efficient level of immigration and the socially optimal level (taking distributive justice into account) will be higher than it would be if we considered only the welfare of natives and immigrants. As before, the optimal quota would allow some migration beyond the economically efficient level, but now economic efficiency is measured with respect to global welfare rather than the welfare of only natives and immigrants. The improvement in the distribution of income produced by these higher quotas would justify some distortion in migration patterns. The optimal quota would equate this marginal gain in social welfare with the marginal efficiency cost of excessive immigration.

We would accept some inefficient migration as part of the cost of redistributive policies that differ among jurisdictions. ${ }^{29}$ After all, even within a unitary state, redistribution entails some deadweight loss because it distorts incentives. From the perspective of global social welfare, why should we regard inefficient migration as any more problematic than these other distortions?

\section{CONCLUSIONS}

The foregoing analysis suggests that current immigration restrictions bear little resemblance to those that would maximize either national or global economic welfare. Indeed, it is difficult to rationalize many of these restrictions as serving any coherent social welfare objective. The pursuit of virtually any economic welfare objective would probably entail levels of employment-based and family-based immigration higher than allowed by current U.S. laws.

If the United States were to maximize the economic welfare of natives, we would eliminate quotas and "labor certification" requirements for all employment-based immigration. We would address issues of distributive justice among natives through fiscal policies

${ }^{269}$ Such inefficient migration is tolerated among jurisdictions within a federal state. See Carens, supra note 26, at 267 ("No liberal state restricts internal mobility."). 
instead. We would offer more skilled workers admission as permanent residents eligible to naturalize as U.S. citizens, and as a further incentive for them to immigrate to the United States, we would also offer to admit their relatives on favorable terms as family-based immigrants. We would use qualitative restrictions rather than quantitative restrictions to regulate family-based immigration as well as employment-based immigration. ${ }^{270}$ Finally, we would admit unskilled aliens as guestworkers without quantitative restrictions or "labor certification" requirements, but deny them access to some public entitlement programs and the earned income tax credit. These policies would present low-income foreign workers with less progressive fiscal policies than those faced by natives.

If we were to maximize a measure of economic welfare that included the welfare of natives and of immigrants on an equal basis, the fiscal policies applied to poor immigrants would be more liberal. These policies would entail less severe discrimination against unskilled immigrants than suggested by the maximization of the economic welfare of natives alone. We would impose quantitative restrictions only on unskilled immigration and only in order to provide poor immigrants with greater access to public entitlements and tax benefits while avoiding excessively high levels of inefficient immigration. In the allocation of visas subject to these quotas, we would give priority to family-based immigrants and refugees. Thus, these policies would be qualitatively similar to our current policies toward unskilled immigrants, but because these policies would reflect concern for the welfare of the immigrants as well as considerations of distributive justice, we would set these quotas at levels much higher than our current immigration quotas. Finally, if the United States were to choose its policies to maximize global economic welfare, we would admit still more unskilled immigrants, and quotas would serve a more limited role in regulating their immigration.

Given that each welfare objective implies a different optimal immigration policy, what implications can we draw for the reform of existing immigration laws? There are some liberalizing reforms that appear likely to improve matters compared to our current immigration laws, under any of our measures of social welfare. Liberalizing reforms that serve the interests of not only immigrants but also U.S. natives may stand the best chance of adoption, especially if we pursue

${ }^{270}$ Thus, we would still exclude immigrants expected to impose negative externalities on natives, such as those "likely at any time to become a public charge" or those with sufficiently egregious criminal records. 
such reforms in modest increments. I present these proposals not as ideal reforms but as the liberalizing reforms that seem most likely to prove politically feasible.

First, we should liberalize or eliminate our quotas on the immigration of skilled workers and eliminate the "labor certification" requirements that impose protectionist restrictions on this immigration. $^{271}$ We should also liberalize our quotas on family-based immigration, subject to the "public charge" exclusion ground, which provides an efficient incentive for skilled immigration while protecting public coffers. Immigration of skilled workers is in the interests of U.S. natives as well as of the migrants. The main question arises with respect to the interests of countries of emigration. If we fear this "brain drain" may be inefficient and thus impose excessive costs on the countries of emigration, then we could offer to help those countries tax the migrants at an appropriate rate. ${ }^{272}$

Second, we should liberalize our existing guestworker programs so as to allow more unskilled immigrants to work in the United States. ${ }^{273}$ We should eliminate "labor certification" requirements for

${ }^{271}$ See Buckley, supra note 124, at 94 (comparing the immigration policies of Canada and the United States and concluding that the "labor certification" requirement, "which has no parallel in Canada, lengthens the American immigration process and weakens the United States in the competition for skilled migrants"); Sykes, supra note 7, at 187 (noting that the "labor certification" requirement "has little to commend it" and that "it is certainly questionable whether any ceiling on the number of visas for skilled immigrants with employer sponsorship is in the national interest").

${ }^{272}$ See 2 THE BRAIN DRAIN AND TAXATION: THEORY AND EMPIRICAL ANALYSIS at vii (Jagdish N. Bhagwati ed., 1976) (exploring a proposal to levy a tax on the incomes of skilled migrants from less developed countries into developed countries). A tax on emigrants would not only curb inefficient migration but also allow countries of emigration to reap some share of the gains from trade enjoyed by the emigrants. Effective enforcement of this tax obligation, however, would require the cooperation of the country of immigration. See Richard A. Musgrave, Foreword to INCOME TAXATION AND INIERNATIONAL MOBILITY, supra note 261, at xv ("In the absence of an international tax authority, administrative cooperation by the country of residence would seem essential for successful implementation.... This might not require outright collection with intergovernmental revenue transfer, but the availability of tax returns from the residency country ... would seem essential."); Pomp, supra note 262, at 62 ("Enforcement... will require the assistance of the host [country]. A host [country] can provide assistance at each stage of the administration of the ... tax by compiling a tax roll, assessing ... tax liability, and collecting the amount of tax owed.").

${ }_{273}$ The Agricultural Committee of the House of Representatives recently sought to attach a guestworker provision to H.R. 2202, 104th Cong. (1995), the immigration bill ultimately enacted by Congress in 1996. See House Panels Add Guestworker Program, Delete Federal Employee Provisions from Reform Bill, 73 INTERPRETER RELEASES 290 (1996). The provision contained some modest liberalizing reforms confined to the agricultural sector. 
guestworkers, which raise protectionist barriers to their employment. We should also liberalize our quotas on these admissions, our restrictions on the duration of their employment, and our limits on the length of their stay in the United States as workers. A liberalized guestworker program is likely to be in the economic interest of natives as a group as well as in the interest of the migrants. One question regarding national economic welfare arises with respect to the costs low-income guestworkers might impose on natives through the public sector. To the extent this problem arises, the appropriate response would be fiscal: if we insist that such migration serve the interest of natives, discriminatory fiscal policies can ensure that guestworkers impose little or no net external costs. ${ }^{274}$ Even with such discriminatory features, a liberalized guestworker program would be an improvement for the many aliens excluded by existing laws. Unskilled guestworkers also raise an issue with respect to the distribution of income among natives, but again the appropriate response is fiscal: to compensate unskilled native workers for any reduction in their real wages, Congress could combine immigration reforms with tax relief for the working poor, such as expansions in the earned income tax credit.

Why has the United States not moved toward the reforms described above? Part of the problem may be the xenophobia and intolerance that have unfortunately always exerted a powerful influence on the formulation of immigration policies. ${ }^{275}$ Part of the explanation may be the same protectionist pressures generated by special interest groups that oppose liberalized trade in goods: those who fear foreign competition lobby for protectionist barriers. Unskilled native workers, for example, may oppose the immigration of guestworkers. To the extent Congress links a liberalized guestworker program with subsidies for the working poor, however, progressive tax reforms de-

\footnotetext{
The House, however, rejected this proposed amendment. See House Approves Immigration Bill After Removing Legal Immigration Restrictions, supra note 22, at 357-58.

${ }^{274}$ Even if guestworkers have a negative effect on the public sector, the gain to natives through the labor market may outweigh the external costs guestworkers impose. Thus, tax revenues need not offset all external costs in order to produce a net gain for natives from the admission of guestworkers.

${ }^{273}$ See Johnson, supra note 4, at 967 (noting "the willingness to allow free trade and the concomitant resistance to free immigration," which "undoubtedly tells us something about ethnocentrism, racism, and classism in the United States" and "suggests that persons may fear difference and change brought by new and different people joining the community").
} 
signed to compensate unskilled labor could help overcome opposition to liberalization.

The United States might also employ the same device used in the international trade context to overcome protectionist opposition to liberalizing reforms: multilateral agreements in which each country agrees to reduce trade barriers in exchange for liberalization by others. The prospect of reciprocal liberalization by our trading partners would mobilize domestic producer interests in support of the agreement that can offset the domestic producer interests opposed to liberalization of our policies. Through such agreements, each country can gain not only by obtaining access to foreign markets but also by overcoming protectionism at home and opening its own market.

So far, the United States has applied a double standard to the liberalization of trade in services:

Although at the level of general principle the United States espoused the idea that negotiations on services should have a comprehensive scope, the US position on the definition of services themselves had the effect of focusing the negotiations on those sectors of most export interest to the United States and other developed countries (e.g. crossborder transactions in sectors such as telecommunications and financial services), while excluding liberalization of factor movements, especially labour, where developing countries might often have a comparative advantage (e.g. ship's crews, construction gangs, etc.). ${ }^{276}$

In the initial negotiations over the GATS, the United States failed in its efforts to obtain a "hard" agreement along GATT lines, with generally binding obligations, including a "national treatment" obligation, which would prohibit discrimination against foreign suppliers of services. ${ }^{277}$

To promote more comprehensive liberalization in the future, the United States could agree to place its own immigration policies pertaining to temporary workers on the negotiating table under the auspices of the GATS. The GATS Annex on Movement of Natural Persons Supplying Services Under the Agreement states that "Members may negotiate specific commitments applying to the movement of all categories of natural persons supplying services under the Agreement.",278

${ }^{276}$ TREBILCOCK \& HOWSE, supra note 2, at 226 (footnote omitted).

${ }^{277}$ See Hoekman, supra note 2 , at 925.

${ }^{278}$ GATS Annex, supra note 12, art. 3, 33 I.L.M. at 1188; see Sauve, supra note 2, at 134 ("The Annex... establishes that Members may negotiate specific commitments applying to the temporary entry of all categories of natural persons."). 
The development of this Annex was-and remains-of particular interest to developing countries, given the comparative advantage many of them enjoy in labour-intensive services (e.g. construction services, software development, engineering design). Recognition of the fact that most developed countries had not included categories of greatest interest to developing-country exporters led to the adoption of a Ministerial Decision calling for negotiations to continue beyond the conclusion of the Uruguay Round and aimed at achieving higher levels of commitments by GATS Members.

In exchange for commitments by the United States regarding temporary workers, the labor-abundant developing countries may be more inclined to agree to liberalize their markets for services in which the United States has a comparative advantage. ${ }^{280}$ The United States would gain not only by reforming its own immigration laws, but also by obtaining commitments from developing countries that they have been reluctant to make thus far (such as a "national treatment" obligation for services). ${ }^{281}$

Liberalized immigration of skilled aliens and of unskilled guestworkers, when combined with appropriate fiscal policies, would serve the national interests of the United States. Indeed, in exchange for sufficiently valuable commitments by developing countries, the United States might go beyond immigration reforms that maximize U.S. economic welfare and move toward those that maximize global economic welfare. The United States might offer its cooperation with countries of emigration seeking to tax an inefficient "brain drain." We might cut our "tariffs" on guestworkers, that is, reduce the degree to which we discriminate against them in terms of our public entitlements. We might also liberalize our restrictions on the access of unskilled aliens to permanent residence and to citizenship.

279 Sauve, supra note 2 , at 135 .

${ }^{280}$ U.S. offers to liberalize immigration policies could prove to be a valuable bargaining chip in negotiations with developing countries. Indeed, Hamilton and Whalley suggest that "liberalization of worldwide migration could possibly be the single most important issue in current North-South exchanges for the South" and that citizens of developing countries "could thus be well served if demands for removal of immigration controls in the North were more forcefully presented." Hamilton \& Whalley, supra note 8, at 75.

${ }^{281}$ The United States could use the same sort of "escape clauses" used in the GATT in the context of trade in goods to provide a "safeguard" in the event of a serious threat to domestic producer interests. See GATT, supra note 1, art. XIX, 61 Stat. pt. 5, at A58, 55 U.N.T.S. at 258. The United States could reserve the right to raise temporary barriers in the event of unexpectedly severe consequences for U.S. workers.

${ }^{282}$ See supra note 272. 
Negotiations would provide a justification for our failure to adopt more liberal immigration laws. Whereas in an ideal world we might adopt more efficient laws, we currently live in a highly nonideal world in which other governments discriminate against our nationals (in their goods markets, service markets, labor markets, or capital markets). Given this reality, we may use costly policies as bargaining chips, offering to reform our protectionist policies in exchange for liberalizing reforms by other governments that discriminate against our nationals. Reforms implemented by all participants, when taken together in a multilateral agreement, allow each to increase its national economic welfare while improving global economic welfare. From this perspective, we discriminate against aliens only in order to gain leverage that allows us to obtain better treatment from foreign governments for our own nationals. ${ }^{288}$ This rationale for our protectionist policies, however, justifies our policies only if we in fact offer to bargain over them. ${ }^{284}$ It is difficult to justify our restrictive immigration laws in the absence of such bargaining.

${ }^{283}$ The Supreme Court has consistently applied minimal scrutiny to the federal government's immigration policies, citing the important federal interest in foreign relations. See supra note 251. "Such interests include the manner in which our citizens might be treated in other countries, bargaining power with other governments, ... or simply the image which the nation wishes to present to the world." NowAK \& ROTUNDA, supra note 107 , at 705 . Rosberg dismisses the "interest in creating a bargaining chip" as a justification for restrictions on immigrant access to Medicare: "[I]n all likelihood there are no negotiations on the subject under way or even remotely foreseeable.... The nexus between the alienage classification and the desire to increase bargaining power seems, to say the least, remote." Rosberg, supra note 113, at 315 n.146. The same observation applies to most of our immigration policies, which would more convincingly implicate foreign-policy interests if they were in fact the subject of international bargaining.

${ }^{284}$ This rationale might be described as a "nonideal" defense of immigration restrictions. Rawls distinguishes between "ideal" and "nonideal" parts of a theory of justice. RAWLS, supra note 245 , at 245-48. The ideal theory describes "a perfectly just basic structure," id. at 245 , whereas the nonideal theory takes account of "historical contingencies," injustice in existing social arrangements, and the unjust conduct of others, id. at 246. Carens concludes that "ideal theory holds up the principle of free migration as an essential part of the just social order toward which we should strive" and that "nonideal theory provides more grounds for restricting immigration than ideal theory, but these grounds are severely limited." Carens, supra note 26, at 262. 